\title{
A UTILIZAÇÃO DE SISTEMAS DE INFORMAÇÃO GEOGRÁFICA NO ESTUDO DA EXPOSIÇÃO HUMMANA AOS PRODUTOS DA QUEIMA DA PALHA DE CANA-DE- AÇÚCAR (Saccharum sp) NO ESTADO DE SÃO PAULO.
}

FÁBIO SILVA LOPES

Dissertação apresentada na Área de Saúde Ambiental da Faculdade de Saúde Pública da Universidade de São Paulo para obtenção do Grau de Mestre.

ORIENTADORA: Prof ${ }^{\text {a }}$. Dr. ${ }^{\text {a }}$ HELENA RIBEIRO

São Paulo

2005 


\section{A UTILIZAÇÃO DE SISTEMAS DE INFORMAÇÃO GEOGRÁFICA NO ESTUDO DA EXPOSIÇÃO HUMMANA AOS PRODUTOS DA QUEIMA DA PALHA DE CANA-DE- AÇÚCAR (Saccharum sp) NO ESTADO DE SÃO PAULO.}

FÁBIO SILVA LOPES

Dissertação apresentada na Área de Saúde Ambiental da Faculdade de Saúde Pública da Universidade de São Paulo para obtenção do Grau de Mestre.

ORIENTADORA: Prof ${ }^{\text {a }}$. Dr. ${ }^{\text {a }}$ HELENA RIBEIRO

São Paulo

2005 
Autorizo, exclusivamente para fins acadêmicos e científicos, a reprodução total ou parcial desta dissertação, por processos fotocopiadores.

Assinatura:

Data: 
Quando eu era pequeno e ainda fazia o primário, minha professora ao solicitar a lista de material para aquele ano letivo, incluía entre os itens umas réguas chamadas de gabarito, com 0 contorno dos mapas do Brasil e de São Paulo. Eu olhava aquele material intrigado e, ao utilizá-lo durante as aulas, perguntava para mim mesmo, prá que serve desenhar tantos mapas? Acho que agora eu sei a resposta. 


\section{AGRADECIMENTOS}

À minha mãe, Dona Carminha, que depois de muitos puxões de orelha implorando para eu estudar, não deve estar acreditando que eu cheguei aqui. Um grande beijo.

Ao Nello, que sempre me acolheu com seu famoso "vai em frente" desde o início do trabalho.

À Simone, querida irmã que fez uma ótima retaguarda nos momentos difíceis desta trajetória. Obrigado mana.

Ao cunhado Roberto, por compartilhar algumas angústias sobre canade-açúcar e afins nas madrugadas de São Bernardo, além da revisão do Summary. Thank you, brother.

Às tias Adelina, Diva e Tereza, obrigado pelo carinho atenção e apoio neste longo período de trabalho.

À Sandra, amiga e companheira de trabalho, pelas revisões de português, sugestões, conversas, apoio, etc. Enfim, como terminaria eu este trabalho sem sua ajuda? Obrigado.

Ao Centro de Vigilância Sanitária da Secretaria de Estado da Saúde de São Paulo, por me apresentar ao mundo da saúde pública e ao geoprocessamento, abrindo novos horizontes em minha carreira profissional.

À Universidade Presbiteriana Mackenzie pelo estímulo à conquista deste título.

À Prof. Helena, que acreditou em minha capacidade, mesmo apesar de se tratar de um informático chegando ao mundo da saúde ambiental, me conduzindo nesta jornada, desde a entrevista de ingresso na FSP, até este momento nestes 2 anos de trabalho. Meu eterno agradecimento. 


\section{RESUMO}

Lopes F.S. A utilização de sistemas de informação geográfica no estudo da exposição humana aos produtos da queima da palha de cana-de-açúcar (Saccharum sp) no estado de São Paulo; 2004. [Dissertação de Mestrado - Faculdade de Saúde Pública da USP].

Introdução. O uso de tecnologias computacionais em pesquisas na área de saúde pública é cada vez mais acentuado devido às facilidades providas ao pesquisador. Em particular, o SIG (Sistema de informação geográfica) auxilia na fusão de dados dispostos em tabelas e mapas contendo aspectos geográficos do local de estudo, através da sobreposição de camadas. Tal fusão possibilita uma nova leitura dos dados associados à dimensão do espaço. Neste aspecto, os programas SIG são ferramentas ideais para estudos de geografia da saúde. Em estudos ecológicos de causa/efeito envolvendo variáveis ambientais e os efeitos deletérios à saúde humana, as tecnologias de geoprocessamento constituem um interessante recurso para gerar hipóteses para estudos mais aprofundados sobre o tema. Objetivo. Este estudo objetivou a construção de um SIG que agregou elementos para verificar a correlação entre os produtos da queima de palha de cana-de-açúcar (Saccharum sp) e a incidência de problemas respiratórios em regiões de entorno afetadas por tais produtos, através das técnicas de análise espacial possíveis com recursos computacionais de geoprocessamento. Metodologia. O desenvolvimento deste trabalho consistiu em coletar e organizar dados de queimadas e internações por afecções respiratórias no período de 2000 a 2004, seguindo da estruturação de um SIG em duas abordagens. Na primeira, considerou-se a abrangência do estado de São Paulo. Foram criadas cartas temáticas das variáveis e identificadas áreas de interesse para estudos em escala local. A segunda abordagem consistiu na construção de um SIG abrangendo a meso-região de Bauru, utilizando a técnica buffer para observar a intersecção dos agravos de saúde em áreas de queimada. Resultados. Foram elaboradas cartas temáticas e uma análise das correlações espaciais encontradas nas duas abordagens e observou-se maior incidência de doenças respiratórias em regiões onde há ocorrência da prática de queimadas em culturas canavieiras. Assim sendo, o material produzido constitui um conjunto de dados que permite ao pesquisador checar hipóteses para subsidiar posteriores estudos no âmbito da saúde ambiental. 


\section{SUMMARY}

Lopes F.S. The use of geographical information systems in the study of human beings exposed to burnt sugar-cane straw (Saccharum $s p$ ) product in the São Paulo state; 2004. [Dissertação de Mestrado - Faculdade de Saúde Pública da USP].

Introduction. The use of computational technologies in researches on public health field is more and more present due to easier tolls available to researchers. In particular, GIS (Geographic Information System) helps to merge tables and maps which contain geographic aspects of the site being studied by overlapping layers. Such merging makes a new understanding of the data linked to the dimension of space possible. Concerning GIS, it is an ideal tool for studying the health geography. Ecological researches analyze causes and effects involving environmental variables and the deleterious effect to human health. Geoprocess technologies are an interesting resource to generate hypotheses for future deeper studies on the subject. Objective. This study aimed at the construction of a GIS that added elements to verify the correlation between the products of the sugar-cane straw burning (Saccharum sp) and the incidence of respiratory problems in the neighborhood and near regions affected by such products by using special techniques analysis with computational resources of geoprocess. Methodology. The development of this work consisted of the collection and organization of data on such burnings and the incidence of respiratory diseases officially registered from 2000 to 2004 in the studied regions. After that, GIS structure was accomplished on two approaches. Firstly it covered the State of São Paulo. Thematic maps based on the variables have been created and, thus areas of interest, in local scale, have been identified. The second approach consisted of the construction of a GIS which covered the mesoregion of Bauru by using buffer technique to observe the intersection of the harmful effects on health in such regions. Results. Thematic maps have been elaborated as well as the analysis of space correlations found in both approaches. As a result, higher incidence of respiratory diseases in regions where such fires had occurred has been observed. Thus, the resulting data will enable any hypothetical researcher to check hypotheses in order to assist his or her further studies in the scope of the environmental health. 


\section{LISTA DE ABREVIATURAS E SIGLAS}

DATASUS: Processamento de Dados do SUS. Empresa pública de processamento de dados ligada ao Ministério da Saúde.

GIS: Geographic Information System (o mesmo que SIG).

GMT: Greenwich Mean Time (Horário no meridiano de Greenwich).

IBGE: Instituto Brasileiro de Geografia e Estatística.

IDW: Inverse Distance Weighting (algoritmo para gerar uma grade de valores a partir do peso médio da distância entre pontos de dados).

INPE: Instituto Nacional de Pesquisas Espaciais.

IPCC: (Intergovernment Panel on Climate Change) Painel Intergovernamental sobre Mudança do Clima.

MS: Ministério da Saúde.

OMM: Organização Mundial de Meteorologia.

OMS: Organização Mundial da Saúde (o mesmo que WHO).

PNUMA: Programa das Nações Unidas para o Meio Ambiente.

SGBD: Sistema Gerenciador de Banco de Dados

SIG: Sistema de Informação Geográfica.

SIH: Sistema de Informações Hospitalares do SUS.

SQL: Structure Query Language (Linguagem estruturada para consultas). Conjunto de comandos padronizados para executar requisições a um banco de dados.

SUS: Sistema Único de Saúde.

VIGISUS: Projeto Vigilância em Saúde do SUS financiado pelo Banco Interamenicano de Desenvolvimento.

WHO: World Health Organization (o mesmo que OMS). 


\section{LISTA DE FIGURAS}

1.Pirâmide representando a proporcionalidade populacional para cada situação possível em casos de exposição ao produto da queima de



2.Principais componentes e interações entre fatores climáticos e meteorológicos e doenças respiratórias crônicas ...............................50

3.Estrutura geral de um Sistema de Informação Geográfica. ............... 61

4. Análise espacial em Saúde Pública, uma abordagem sistemática



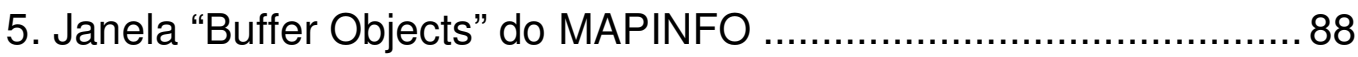

6.Janela "Image Registration" do MAPINFO …….................................. 89 


\section{LISTA DE QUADROS}

1.Desafios comuns na pesquisa epidemiológica de poluentes

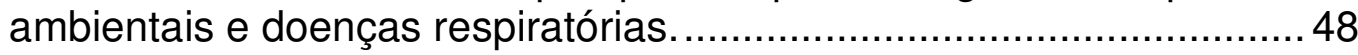

2. Dicionarização da tabela associada à carta digitalizada da malha

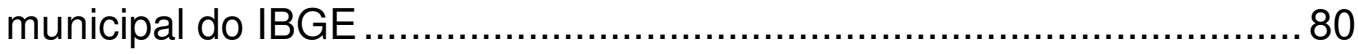

3. CID-10, Capítulo 10: Doenças do aparelho respiratório (J00-J99) .. 82

4. Dicionarização da tabela obtida na consulta de procedimentos

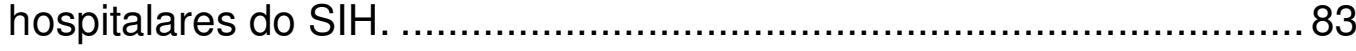

5. Dicionarização da tabela de focos de calor detectados por satélite, disponibilizada pelo INPE - Monitoramento de Queimadas .................86 


\section{LISTA DE MAPAS}

1. Focos de calor decorrente de queimadas no Estado de São Paulo 14

2. Óbitos por cólera em Broad Street e arredores (Londres, 1854).....63

3. Distribuição da proporção de domicílios positivos para a presença de Lutzomyia Longipalpis e do número de exemplares capturados em Araçatuba, São Paulo, 1998 - 1999.

4. Monitoramento do aquecimento das águas oceânicas em Piraquara de Fora RJ. 68

5. Distribuição da densidade de residências de vítimas de homicídio, Porto Alegre, 1996. 68

6. Fluxo de Índios Kaingang em busca de assistência do SUS. 69

7. Coeficiente de Mortalidade Infantil, por Distrito Sanitário em Belo Horizonte, 1994.. 70

8. Medições de concentração média anual de $P M_{10}$ na região metropolitana da Cidade do México (2000). 70

9. Medições de concentração média anual de $\mathrm{PM}_{10}$ e população potencialmente exposta no município de São Paulo, São Paulo, 1995.

10. Medições de concentração média anual de $\mathrm{PM}_{10}$ e população potencialmente exposta no município de São Paulo, São Paulo, 2000 71

11. Distribuição das áreas de plantio de cana-de-açúcar no estado de São Paulo nas meso-regiões estaduais. 93

12. Focos de calor no estado de São Paulo no ano de 2000, distribuídos nas Meso-Regiões administrativas estaduais. 94

13. Focos de calor no estado de São Paulo no ano de 2001, distribuídos nas Meso-Regiões administrativas estaduais. 95

14. Focos de calor no estado de São Paulo no ano de 2002, distribuídos nas Meso-Regiões administrativas estaduais. 
15. Focos de calor no estado de São Paulo no ano de 2003, distribuídos nas Meso-Regiões administrativas estaduais. 96

16. Focos de calor no estado de São Paulo no ano de 2004, distribuídos nas Meso-Regiões administrativas estaduais.

17. Distribuição da incidência de internações por afecções nas vias respiratórias e focos de calor no estado de São Paulo no ano de 2000, nas meso-regiões administrativas estaduais 97

18. Distribuição da incidência de internações por afecções nas vias respiratórias e focos de calor no estado de São Paulo no ano de 2001, nas meso-regiões administrativas estaduais 98

19. Distribuição da incidência de internações por afecções nas vias respiratórias e focos de calor no estado de São Paulo no ano de 2002, nas meso-regiões administrativas estaduais 98

20. Distribuição da incidência de internações por afecções nas vias respiratórias e focos de calor no estado de São Paulo no ano de 2003, nas meso-regiões administrativas estaduais 99

21. Distribuição da incidência de internações por afecções nas vias respiratórias e focos de calor no estado de São Paulo no ano de 2004, nas meso-regiões administrativas estaduais 99

22. Grade de distribuição da incidência de internações por afecções nas vias respiratórias e focos de calor no estado de São Paulo no ano de 2004, nas meso-regiões administrativas estaduais, gerada pelo interpolador IDW. 101

23. Distribuição da incidência de internações por afecções nas vias respiratórias e buffer dos focos de calor nas meso-regiões administrativas do estado de São Paulo no primeiro trimestre do ano de 2004. 104

24. Distribuição da incidência de internações por afecções nas vias respiratórias e buffer dos focos de calor nas meso-regiões administrativas do estado de São Paulo no segundo trimestre do ano de 2004 104

25. Distribuição da incidência de internações por afecções nas vias respiratórias e buffer dos focos de calor nas meso-regiões administrativas do estado de São Paulo no terceiro trimestre do ano de 2004 
26. Distribuição da incidência de internações por afecções nas vias respiratórias e buffer dos focos de calor nas meso-regiões administrativas do estado de São Paulo no quarto trimestre do ano de 2004 105

27. Meso-região de Bauru parcial apresentando a localização dos centros urbanos e áreas de plantio de cana-de-açúcar ................. 108

28. Distribuição da incidência de internações por afecções nas vias respiratórias e buffer dos focos de calor na meso-região administrativa de Bauru, do estado de São Paulo no primeiro trimestre de 2004 109

29. Distribuição da incidência de internações por afecções nas vias respiratórias e buffer dos focos de calor na meso-região administrativa de Bauru, do estado de São Paulo no segundo trimestre de 2004 109

30. Distribuição da incidência de internações por afecções nas vias respiratórias e buffer dos focos de calor na meso-região administrativa de Bauru, do estado de São Paulo no terceiro trimestre de 2004. 109

31. Distribuição da incidência de internações por afecções nas vias respiratórias e buffer dos focos de calor na meso-região administrativa de Bauru, do estado de São Paulo no quarto trimestre de 2004. 109 


\section{LISTA DE GRÁFICOS}

1. Evolução da concentração de $\mathrm{CO}_{2}(\mathrm{ppm})$ na atmosfera ...................32

2. Evolução comparativa entre as ocorrências de internações por afecções das vias respiratórias e os focos de calor no estado de São

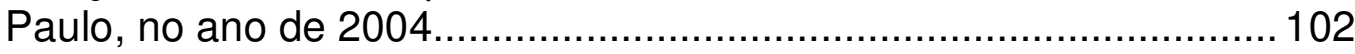

3. Comparativo entre ocorrências de focos de calor e internações por afecções na meso-região de Bauru e micro-região de Jaú nos trimestre

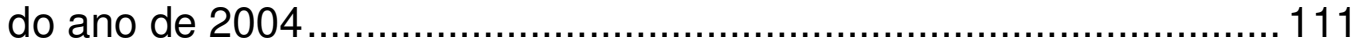




\section{LISTA DE TABELAS}

1. Comparativo de ocorrência de focos de calor na meso-região de Bauru e micro-região de Jaú no ano de 2004 ..................................110

2. Comparativo de ocorrência de internações por afecção das vias respiratórias na meso-região de Bauru e micro-região de Jaú no ano

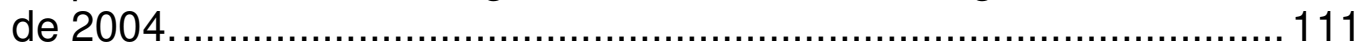




\section{ÍNDICE}

SUMMARY

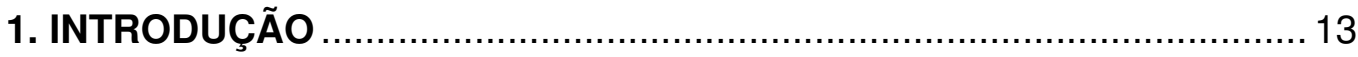

\section{OBJETIVOS}

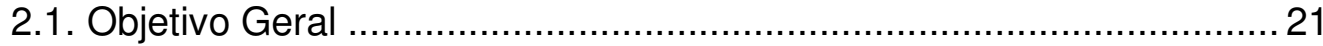

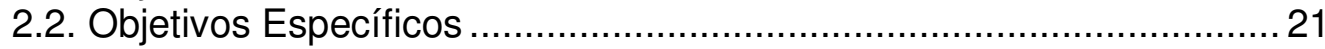

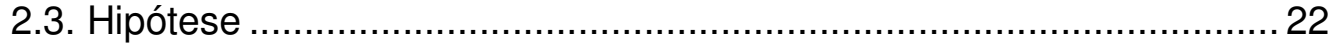

\section{REVISÃO BILIOGRÁFICA}

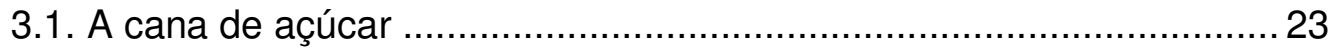

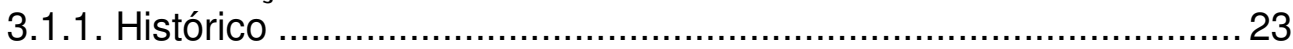



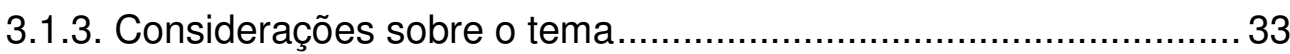

3.2. O Ambiente no contexto da Saúde Pública ……………………...... 35

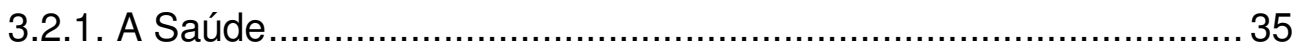

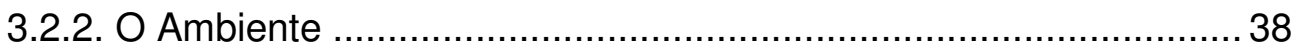

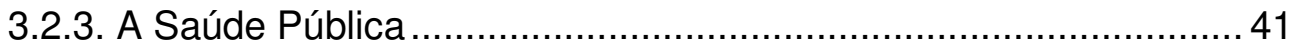

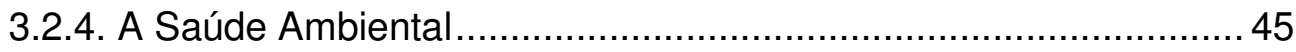

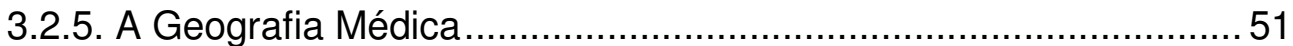

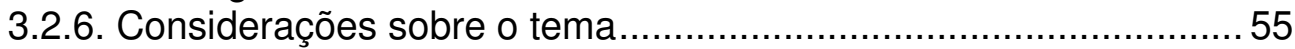

3.3. O Geoprocessamento na Saúde Ambiental .....................................57

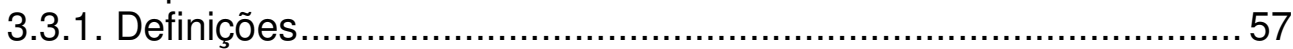

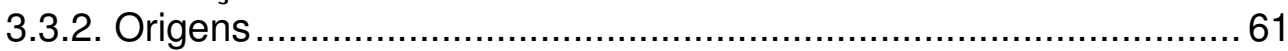

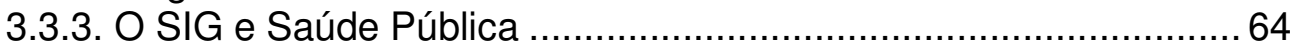

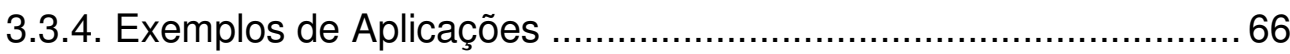

3.3.5. Considerações sobre o tema .................................................... 71

\section{METODOLOGIA}

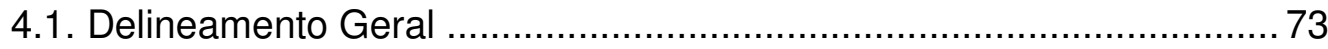

4.1.1. Enfoque Regional ............................................................ 76

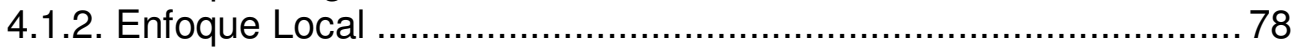

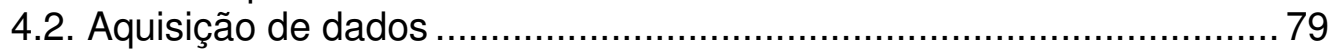

4.2.1. Malha municipal do estado de São Paulo .................................... 80

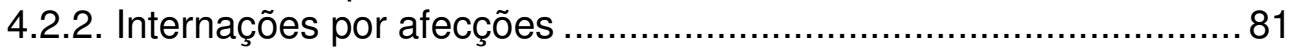

4.2.3. Focos de calor captados por satélite .......................................... 84

4.2.4. Áreas de plantio de cana-de-açúcar no estado de São Paulo....... 88 
4.3. Estruturação do SIG

90

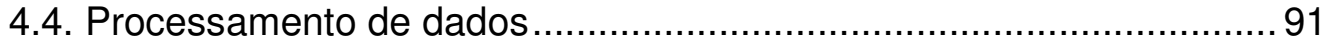

5. RESULTADOS E ANÁLISE

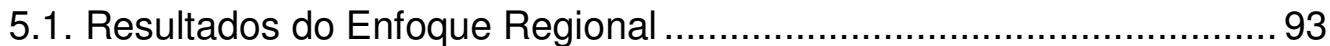

5.2. Análise do Enfoque Regional ....................................................... 100

5.3. Resultados do Enfoque Local.................................................... 107

5.4. Análise do Enfoque Local................................................................ 112

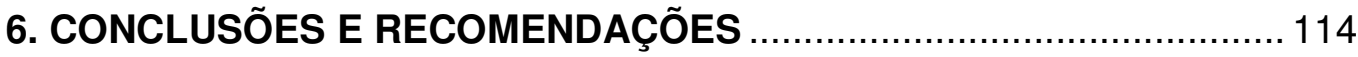

7. REFERÊNCIAS 


\section{INTRODUÇÃO}

O Brasil é o maior produtor de cana-de-açúcar (Saccharum sp) do mundo. Atualmente 4,5 milhões de hectares do território nacional são utilizados para o plantio de cana, representando $1 \%$ das terras agricultáveis, ou o espaço equivalente a 2 vezes o Estado do Piauí. Atualmente, a produção nacional é de 290 milhões de toneladas/ano (EMBRAPA, 2004). Da safra canavieira, 55\% são destinados à produção de álcool e subprodutos, enquanto que os demais $45 \%$ são destinados à produção de açúcar e subprodutos. Este ramo da agroindústria representa $6 \%$ do PIB brasileiro (ÚNICA, 2003).

A história da cana-de-açúcar confunde-se com a história do Brasil. Em 1533, Martim Afonso de Souza, deu início à colonização do Brasil, trazendo em sua bagagem as primeiras mudas desta gramínea, que, em pouco tempo colocou o Brasil como o maior produtor mundial de cana-de-açúcar.

A ocupação do território paulista, sob o ponto de vista da organização agrícola, se deu em meados do século XIX com a grande empreitada do café (MONTEIRO, 2001). Somente após este ciclo, as áreas produtivas deram lugar à lavoura de cana-de-açúcar.

Atualmente, as áreas de plantio de cana-de-açúcar brasileiras estão concentradas principalmente nas regiões Centro-Sul e Nordeste. Tais concentrações permitem dois períodos de safra por ano (março a outubro na região Centro-Sul e novembro a abril na região Nordeste) e a lavoura de cana-de-açúcar emprega 1 milhão de trabalhadores em uma atividade que ainda possui $80 \%$ do corte executado por processos manuais. 
Com natureza predominantemente planáltica, o Estado de São Paulo possui características de mesotermia subtropical, estando sujeito a temperaturas elevadas no verão, ao mesmo tempo em que se beneficia de ondas de refrigério graças à participação dos sistemas atmosféricos extra tropicais (FERRAZ, 1954 citado por MONTEIRO, 1976). Essas características climáticas são favoráveis à lavoura de cana-de-açúcar.

O Estado de São Paulo possui 2,35 milhões de hectares com plantio de cana-de-açúcar distribuídos em 1200 fazendas. A colheita mecanizada já acontece em $25 \%$ desta área. Porém, a prática da queima de biomassa antes da colheita manual ainda é grande e ocorre em vários pontos do Estado, no período entre os meses de maio e outubro. O mapa 1 apresenta focos de calor captados pelo satélite NOAA em 18 de maio de 2003, no Estado de São Paulo, provenientes de queimadas em cultivo de cana-de-açúcar.

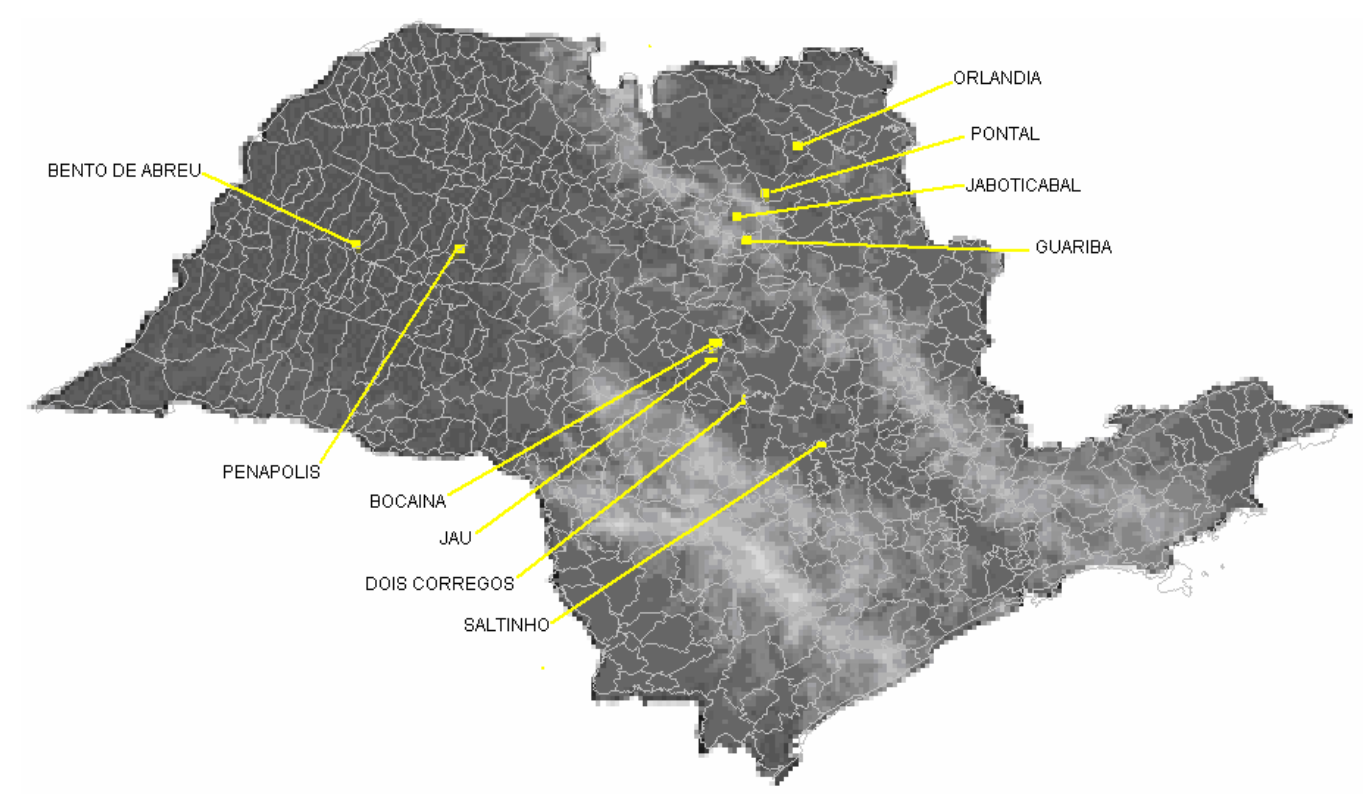

Mapa 1 - Focos de calor decorrente de queimadas no Estado de São Paulo: Foto do Satélite NOAA 12 em 18/05/2003. Fonte: IBGE, 2004; INPE, 2003; Organizado pelo autor. 
O corte manual é precedido pelo processo de queima da palha da planta. Esta técnica facilita o trabalho dos coletores, além de melhorar as condições de segurança, uma vez que animais peçonhentos, que se abrigam na área de plantio, são mortos ou expulsos do local.

A prática de queimar a palha da cana-de-açúcar, antes do corte, causa uma modalidade de poluição do ar. Enquanto a emissão veicular de material particulado pode chegar a 62 toneladas/dia na região metropolitana de São Paulo (equivalente a 2,8\% da área total do Estado de São Paulo) o material particulado proveniente da queima de palha, conhecido como "carvãozinho" pode chegar a 285 toneladas por dia, a considerar uma área de plantio que representa $8,2 \%$ da área total do Estado de São Paulo. Ou seja, enquanto os veículos produzem $8,8 \mathrm{Kg} / \mathrm{Km}^{2}$ de material particulado na Região Metropolitana por dia, as queimadas geram $14 \mathrm{Kg} / \mathrm{Km}^{2}$ de material particulado em áreas de plantio (ZANCUL, 1998).

É sabido que em época de queimada, há uma procura maior aos serviços de saúde em decorrência de problemas respiratórios. Entre 1995 e 1999, a taxa de mortalidade por doenças do aparelho respiratório na Região Sudeste, manteve a média de 11,7\% apresentando 69,3 óbitos por 100.000 habitantes (MELLO JORGE et. al, 2001). Porém, é importante salientar que a população das localidades no entorno das áreas de queimada, aumenta em função dos trabalhadores que lá chegam para trabalhar na colheita da canade-açúcar.

Com relação aos padrões de qualidade do ar para o Estado de São Paulo, o governo estadual publicou a Lei no 997, de 31 de maio de 1976, que dispõe sobre a prevenção e o Controle da Poluição do Meio 
Ambiente. Tal lei foi regulamentada pelo decreto estadual $n^{\circ} \mathbf{8 . 4 6 8}$, de 8 de setembro de 1976. Especificamente no Título 3, Capítulo I, alguns padrões foram definidos para a qualidade do ar. Este decreto define um plano de emergência para episódios críticos de poluição do ar e, somente então coloca situações de proibição de queima, ainda que, de modo genérico.

Mais adiante, em 19 de setembro de 2002, o governo do Estado de São Paulo publicou a Lei № 11.241 que dispõe sobre a eliminação da queima da palha da cana-de-açúcar. Esta lei foi regulamentada pelo decreto $\mathrm{n}^{0} \mathbf{4 7 . 7 0 0}$, de 11 de março de 2003, que apresenta, em seu artigo $2^{\circ}$, a tabela de eliminação gradativa, no prazo de 30 anos (finalizando em 2031). Até lá, a população que vive no entorno das áreas de queimada, continuará a sofrer as interferências negativas do "carvãozinho" no cotidiano.

Do ponto de vista da saúde pública, vários autores descrevem os efeitos deletérios conseqüentes do material particulado proveniente da queima da palha da cana-de-açúcar na vida da população. ZANCUL (1998) cita os seguintes problemas relatados por moradores localizados em áreas impactadas:

- Sujeira em casas, comércio e locais públicos;

- Aumento do consumo de água de abastecimento público para garantir a limpeza dos locais afetados com maior freqüência;

- Aumento dos acidentes em rodovias devido à falta de visibilidade;

- Problemas respiratórios, notadamente em crianças e idosos;

- Interrupção de serviços de energia elétrica por problemas causados em linhas de transmissão próximas a área da queimada; 
- Desperdício de energia;

- Eliminação de animais silvestres, pássaros, etc.;

- Emissão de gases prejudiciais ao meio ambiente;

- Destruição da palha que não se incorpora ao solo.

Nos estudos epidemiológicos que envolvem poluição do ar e saúde, a determinação exata da exposição é um requisito importante para avaliação de seus possíveis efeitos. Segundo CASTRO, GOUVEIA e ESCAMILLA-CEJUDO (2003), exposição a um poluente pode ser definida como um evento que consiste na relação entre o homem e o ambiente, dada uma concentração específica de poluente ambiental em um intervalo de tempo determinado.

Os agravos geralmente relacionados ao tema são as doenças pulmonares obstrutivas crônicas, neste grupo estão incluídos o complexo efisema-bronquite e asma-brônquica. As doenças neoplásicas, pulmonares congênitas ou adquiridas estão excluídas deste grupo, mas não há estudos conclusivos a respeito da relação entre estas e a poluição do ar (RIBEIRO, 1988).

A Organização Mundial de Saúde, em sua publicação denominada "Diretrizes de Saúde para Eventos de Fogo em Vegetação", esclarece que a queima de biomassa gera problemas basicamente em duas áreas ambientais (WHO, 1999):

- Poluição atmosférica - impacto direto da fumaça na saúde humana e economia, influência de gases e emissões de partículas na composição da atmosfera;

- Biodiversidade - conseqüências deletérias no desempenho dos ecossistemas e na estabilidade da paisagem. 
A maior parte da literatura que trata de emissões atmosféricas produzidas pela queima de biomassa aponta que estas causam efeitos deletérios à saúde humana. A Organização Mundial da Saúde sugere que há impacto sobre a mortalidade diária, admissões hospitalares, visitas a emergência e ao ambulatório e sobre a função pulmonar como mostra a figura 1 (WHO, 1999). Contudo, os estudos dos efeitos que o material particulado produzido pelas queimadas podem causar à saúde humana são escassos (ARBEX, 2001). Parte deste problema ocorre devido à variedade de aspectos que envolvem o problema, tornando difícil separar causas isoladas de um determinado efeito.

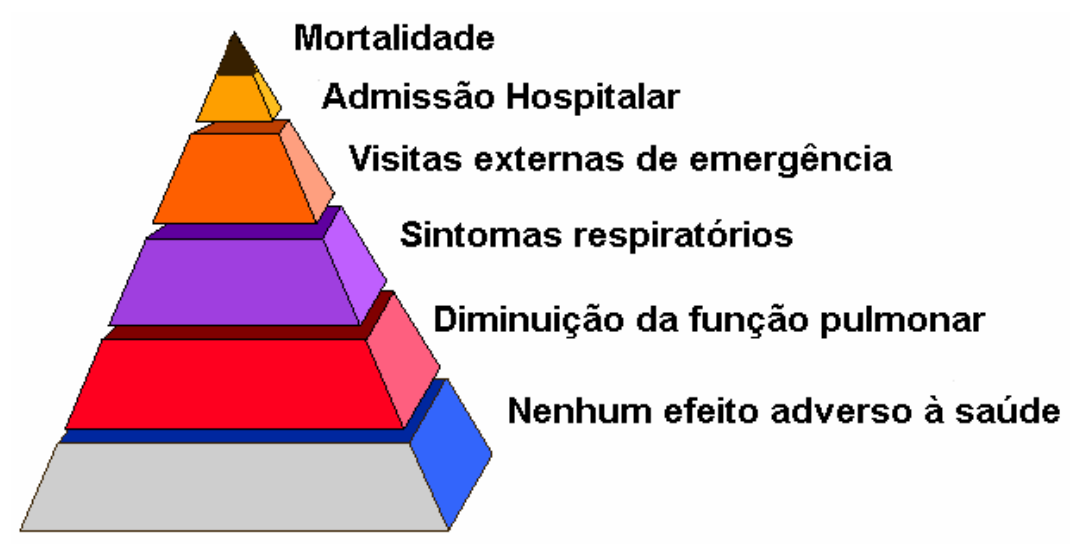

Figura 1: Pirâmide representando a proporcionalidade populacional para cada situação possível em casos de exposição ao produto da queima de biomassa. (Adaptado de WHO, 1999).

As doenças respiratórias crônicas são variáveis dependentes deste trabalho, pois estão diretamente relacionadas com a poluição atmosférica. Estão elas descritas na décima revisão da CID (Classificação Internacional de Doenças), no capítulo 10 que agrupa doenças respiratórias (WHO, 1993). Estudos relatam que pacientes com doenças crônicas do aparelho respiratório, principalmente bronquite crônica, enfisema e asma, referem agravamento dos seus 
sintomas no período do ano que coincide com a queimada da cana. Outros referem com freqüência irritação em vias aéreas superiores, com ardor no nariz e na garganta (ARBEX, 2001).

Do ponto de vista ambiental, é possível construir uma lista de condicionantes com interferência direta em saúde pública. Um conjunto de fatores climáticos e meteorológicos pode influenciar diretamente a incidência de doenças respiratórias crônicas (MIRANDA et. al, 1995).

$\mathrm{Na}$ busca pelo entendimento do potencial risco à saúde promovido por fatores ambientais, novas abordagens despontam no cenário internacional. Por exemplo, a HIA - Helth Impact Assessment, proposta pela London Health Commission, consolida um conjunto de mecanismos com propósito de reduzir a iniqüidade na saúde pública, partindo do princípio de assegurar que todas as políticas e práticas de diversos setores públicos considerem a avaliação do impacto em saúde (LONDON HEALTH COMMISSION, 2000).

Considerando que há uma relação entre a distribuição dos agravos à saúde e o espaço onde eles ocorrem, é importante conhecer como se dá tal distribuição, bem como a evolução dos impactos à saúde da população em uma determinada localidade. Da mesma forma que a epidemiologia e a cartografia sempre estiveram interrelacionadas, a construção de mapas contendo dados de saúde permite observar fenômenos que nem sempre são possíveis de identificar com dados dispostos em tabelas. A utilização de ferramentas de Sistemas de Informação Geográfica - SIG, apresentase como instrumental agregador e analisador de variáveis necessário para estudos ecológicos desta natureza. 
Os recursos computacionais permitem trabalhar com grandes volumes de dados de forma mais rápida e eficiente. As técnicas de geoprocessamento facilitam a associação de bases gráficas e não gráficas de forma a produzir cartas temáticas com mais qualidade e precisão. Com isso, os produtos gerados, através de convenções e representações, são convertidos em informações que podem subsidiar decisões e conseqüente desencadeamento de ações de saúde pública.

No conjunto de elementos apresentados, este trabalho se propõe a unir os aspectos de saúde pública aos fatores ambientais através da tecnologia da informação, sedimentando a abordagem interdisciplinar, cada vez mais presente e imprescindível em estudos de saúde ambiental, que, em função da complexidade de sua natureza, não encontra resposta em uma só ciência.

Pretende-se, com este trabalho, contribuir para o aprimoramento do uso de tecnologias computacionais na área de saúde ambiental, visando a promoção da saúde pública e a melhoria da qualidade de vida das pessoas. 


\section{OBJETIVOS}

\subsection{Objetivo Geral:}

Este estudo ecológico com característica exploratória objetivará, em termos gerais, discutir os benefícios do uso de técnicas de geoprocessamento em saúde, através da construção de um SIG - Sistema de Informação Geográfica que agregará dados sobre a incidência de internação por afecções respiratórias, bem como os focos de calor provenientes da queima de palha de cana-de-açúcar no Estado de São Paulo, para avaliar a possível existência de correlação espacial entre as ocorrências, aplicando técnicas de análise espacial de dados.

\subsection{Objetivos Específicos:}

- Construir mapas temáticos apresentando a incidência de internações por afecções respiratórias e localização dos locais de ocorrência de queimadas no Estado de São Paulo em um período de 5 anos, para avaliar a evolução deste tipo de agravo em função do problema ambiental.

- Construir mapas temáticos apresentando a incidência de internações por afecções respiratórias e localização dos locais de ocorrência de queimadas no Estado de São Paulo no período de 1 ano, agregando dados por trimestre, com o intuito de estudar as questões sazonais associadas ao período de queima da palha de cana.

- Identificar áreas de interesse para estudos em escala local.

- Construir mapas ampliando a escala para visualizar uma meso-região administrativa do Estado de São Paulo, escolhida no final da primeira fase 
do estudo, agregando dados por trimestre, com o intuito de observar os fenômenos com maior riqueza de detalhes.

- Utilizar a análise buffer para observar as intersecções entre as áreas afetadas pelas queimadas e os locais de maior incidência de internação.

- Elaborar uma análise das cartas temáticas e resultados obtidos, fomentando a discussão sobre as vantagens da utilização das ferramentas computacionais.

\subsection{Hipótese}

As tecnologias de SIG - Sistemas de Informação Geográfica, são ferramentas úteis em estudos de avaliação de impactos à saúde respiratória em função da exposição humana aos compostos produzidos pela queima da palha da cana-de-açúcar. 


\section{REVISÃO BIBLIOGRÁFICA}

\subsection{A CANA-DE-AÇÚCAR}

\subsubsection{Histórico}

A cana-de-açúcar (Saccharum sp) pertence a tribo Andropogoneae, família das gramíneas (Gramineæ), gênero Saccharum, espécie S. Officinarum (PINTO, 1965). Tal termo latim derivou do vocábulo sânscrito sarkara, ou sakkara, "açúcar branco", cuja menção em documentos indianos, figura como a mais antiga citação sobre a planta. O radical sânscrito também originou as palavras sukkar (árabe), sakharon (grego), zuchero (italiano), suggar (inglês), sucre (francês) e açúcar (português) (PINTO, 1965).

Acredita-se que esta planta, nativa da Nova Guiné, é conhecida e apreciada pelo ser humano há cerca de 3 mil anos, desde as antigas civilizações da Ásia meridional (CANÇADO, 2003).

A história registra que em $325 \mathrm{AC}$, Nearchus, um dos oficiais de Alexandre, o Grande, relatou a existência da cana-de-açúcar, até então desconhecida na Europa. Documentos originários da Índia comprovam que no século IV AC, os métodos de cultivo já eram bem conhecidos (PINTO, 1965).

Do oriente para o ocidente, a cana-de-açúcar foi introduzida na Pérsia, no século VI DC, e deste ponto, foi levada pelos árabes para as regiões mediterrâneas, especialmente Egito, Marrocos, Espanha e Sicília. 
Já no século $X V$, os portugueses e espanhóis levaram as primeiras mudas para as ilhas Madeira, Canárias, Cabo Verde e São Thomé, bem como para a África Ocidental.

Em sua segunda viagem para a América, no ano de 1493, Colombo introduziu a cultura da cana-de-açúcar nas então chamadas Índias Ocidentais. O primeiro engenho das Américas foi instalado no povoado de Isabela em 1508 estendendo para o continente americano durante os séculos XVI e XVII (PINTO,1965; ZANCUL,1998).

No Brasil, indícios históricos apontam que a cultura da cana-deaçúcar foi introduzida no continente em 1502 devido ao esgotamento das possibilidades de expansão da cultura nas ilhas portuguesas. As condições geográficas e climáticas, bem como solos férteis e úmidos do continente, possibilitaram dois tipos predominantes de lavoura: $A$ "marinha", na região litorânea próxima ao mar e a "serra acima", nas margens dos rios (ARBEX, 2001; CANDÉ, 1971; SOARES, 2000).

A tríplice correlação entre a constituição do terreno, água e o clima, encontrada ao longo do litoral, permitiu o desenvolvimento da cultura agrária no Brasil, a partir de 2 pontos distintos: São Paulo e Pernambuco. Entre outros méritos, a vila de São Vicente na capitania de mesmo nome, construiu em 1533 o primeiro engenho brasileiro, obra de Martin Afonso, que importou as primeiras mudas originárias da Ilha da Madeira. Tal engenho não só prosperou, como se tornou o centro de irradiação da cultura da cana e do fabrico do açúcar, no litoral, e no planalto (AZEVEDO, 1958).

A cultura de cana-de-açúcar se consolidou no nordeste nas várzeas do Capiberibe e do Ipojuca, através da concessão de sesmarias. O segundo engenho data de 1535 e foi instalado nos arredores de Olinda, na capitania de Pernambuco, com o nome de 
Nossa Senhora da Ajuda. Porém há evidências do funcionamento de artefatos para o fabrico do açúcar na região de Itamaracá, anteriores a estas datas. (FREYRE, 1937;FREYRE, 1968 citado por CANDÉ, 1971).

Ao que parece, as primeiras queimadas ocorreram devido a necessidade de desmatamento dessas regiões para o plantio da canade-açúcar conforme relata FREYRE, 1937:

"Antes da canna, havia um arvoredo tanto e tamanho e tão basto e de tantas prumagens que não podia homem dar conta".

Na mesma obra, FREYRE (1937) completa:

\begin{abstract}
"O cannavial desvirginou todo esse matto-grosso do modo mais crú: pela queimada. $O$ fogo é que fora se abrindo no matto virgem os claros por onde se estendeu o cannavial civilizador, mas ao mesmo tempo devastador".
\end{abstract}

Abria-se uma área de lavoura utilizando a queimada. Plantavase diretamente sobre as cinzas da biomassa queimada sem nenhum preparo do solo. Tal processo garantia fertilidade por 2 ou 3 anos. Com o solo desgastado, os senhores de engenho reivindicavam novas sesmarias para dar continuidade ao processo, formando um circulo vicioso entre queimadas e novas terras (PADUA, 2002).

Sobre este mesmo aspecto, PADUA (2002) ressalta que ao invés de alimentar as caldeiras do engenho com o próprio bagaço da 
cana, grandes extensões de mata atlântica eram cortadas e transformadas em lenha.

Este período de grande desenvolvimento do setor canavieiro teve predominância no Nordeste brasileiro, desde 1580 até 1822 e ficou conhecido na história do Brasil como ciclo da cana-de-açúcar (AMARAL, 1958).

Além das Capitanias de São Paulo e Pernambuco, o recôncavo baiano também desenvolveu tal cultura. Em 1590, a Bahia contava com 36 engenhos, no mesmo tempo que São Vicente possuía 13 engenhos e Pernambuco, 66. No ano de 1600, o Brasil já contabilizava 120 engenhos. Na época da invasão holandesa, eram 166, com safra estimada de 1 milhão de arrobas (MARÇAL, 1966 citado por CANDÉ, 1971).

Entre a chegada dos colonizadores e a consolidação da agroindústria canavieira, decorreram aproximadamente sessenta anos. No final do século XVI, Pernambuco e Bahia firmavam-se como pólos produtores enquanto que São Vicente entrava em declínio (ARBEX, 2001).

O Brasil tornou-se o maior produtor mundial de açúcar no início do século XVII. Toda produção brasileira era encaminhada aos portos portugueses que servia de entreposto para os portos holandeses, que de fato eram os controladores do comércio no mercado europeu. Com a união das coroas portuguesa e espanhola em 1580 os holandeses foram proibidos de receber açúcar brasileiro de Lisboa. Tal proibição levou os holandeses a invadir o nordeste brasileiro, permanecendo aqui por 25 anos (CANÇADO, 2003). 
Em Campos dos Goitacazes, existiam 168 engenhos em 1778, este número cresceu para 200 em 1801, 360 em 1815, chegando a 400 moinhos em 1820, além de 12 oficinas de destilação (DENIS, 1955 citado por CANDÉ, 1971).

Neste final de século XVIII e início de século XIX, a cana-deaçúcar em São Paulo não era uma atividade de real importância comercial em seu núcleo primitivo de expansão, a ilha de São Vicente. A produção "marinha" concentrava-se em Ubatuba, São Sebastião e Ilha Bela (SOARES, 1970).

Fatores como a exigüidade de áreas apropriadas à agricultura no litoral contrapondo às amplas possibilidades de expansão no planalto, além de medidas administrativas da capitania no sentido de restringir o cultivo no litoral norte, centralizando o comércio exterior no porto de Santos, favoreceram o desenvolvimento do cultivo no planalto ou "serra acima", apesar das dificuldades do transporte na época (SOARES, 1970).

Os holandeses, quando expulsos do nordeste brasileiro, aliaramse a produtores da América Central e disseminaram as técnicas aprendidas no Brasil. Isto fez esta região se transformar em grande produtora açucareira. Entre outros fatores, a proximidade geográfica da Europa favoreceu um novo equilíbrio no mercado da cana-deaçúcar (ARBEX, 2001).

Fatores históricos como a abertura dos portos às nações amigas em 1808 e a proclamação da independência em 1822, contribuíram para que Brasil voltasse a ocupar a classificação de maior produtor de açúcar do mundo. Porém, a dependência da mão de obra escrava implicou em poucos investimentos na tecnologia da produção, levando 
- Brasil a ocupar a quinta posição no mercado mundial na segunda metade do século XIX (ARBEX, 2001).

O século XIX foi marcado pelo declínio da importância do açúcar finalizando o chamado ciclo da cana-de-açúcar. A produção no Estado de São Paulo entrou em decadência e as lavouras de cana-de-açúcar foram substituídas pelo plantio do café, em ascendência no mesmo período, iniciando o ciclo do café (SOARES, 1970).

No período de 1894 a 1914, diante de graves e sucessivas crises no mercado cafeeiro, os agricultores paulistas, passaram a substituir a cultura do café por produtos em ascensão no mercado interno, como arroz, cana-de-açúcar, feijão e milho. Este processo consolidou-se no Estado de São Paulo somente após a crise de 1929 (SOARES, 1970).

Em particular a cana-de-açúcar contava com 14 engenhos no período de 1911 a $1920 \mathrm{com}$ a produção de 3000 toneladas/dia no Estado de São Paulo. Entre 1900 e 1930, somente no nordeste, foram implantadas 80 novas usinas (ARBEX, 2001; SOARES, 1970).

Após a crise de 1929/1930, as plantações de cana-de-açúcar expandiram-se pelo Estado de São Paulo, ocupando antigas áreas de produção de café, em marcha para a auto-suficiência (CANÇADO, 2003).

Em 1933, o Brasil passava por uma crise interna de superprodução açucareira, fato este que motivou a criação do Instituto do Açúcar e do Álcool (IAA), com a finalidade de regular a produção de cana-de-açúcar, protegendo o Brasil no mercado internacional. Esta intervenção estatal buscou restabelecer o equilíbrio entre produto e 
consumo, através da fixação de quotas de produção para todas as usinas e bangüês ${ }^{1}$ do país (ARBEX, 2001; SOARES, 1970).

Entre as medidas adotadas nesta época, decidiu-se pela obrigatoriedade da adição de álcool à gasolina na ordem de 5\%. Durante a segunda guerra mundial, a proporção aumentou para $20 \%$ a título de aditivo ao combustível, com o intuito de minimizar a utilização de petróleo (CANÇADO, 2003).

A década de 1940 agregou outros fatores à história, como a entrada do Brasil na segunda guerra mundial e o elevado ritmo industrial no Estado de São Paulo. Estes fatores estimularam o incremento populacional e gerou uma crise de abastecimento no Estado. O sistema de transportes de cabotagem brasileiro passava por serias dificuldades que impossibilitava o escôo da produção de açúcar nordestina para São Paulo.

Tal problema resultou na revisão de quotas favorecendo São Paulo que, na safra 1946/1947 passou de terceiro para segundo lugar entre os produtores brasileiros. Na safra 1951/1952 São Paulo ultrapassou a produção de Pernambuco alcançando o primeiro lugar na produção nacional. A safra seguinte voltou para o segundo lugar e São Paulo assumiu definitivamente 0 primeiro lugar na safra 1953/1954 (SOARES, 1970).

A história da cana-de-açúcar entra em evidência novamente na década de 1970 com o aumento dos preços do petróleo. O governo federal começou a planejar uma forma de incentivar a produção do álcool e outros combustíveis alternativos para uso veicular (ZANCUL, 1998). Esta possibilidade já era conhecida desde a Primeira Guerra

\footnotetext{
${ }^{1}$ Engenho de Açúcar primitivo, anterior à usina (AURÉLIO, 1988).
} 
Mundial quando o álcool fora estudado como combustível alternativo aos derivados do petróleo (CANÇADO, 2003).

Em 14 de novembro de 1975, o decreto federal no 76.593 criou o Próalcool (Programa Nacional do Álcool), cuja finalidade foi gerar incentivos para incrementar as safras agro-energéticas e a capacidade industrial de transformação, com ênfase para o álcool anidro, utilizado na mistura com a gasolina. No ano de 1978, desenvolveu-se a tecnologia que possibilitou produzir os primeiros veículos movidos exclusivamente a álcool. O Próalcool fez com que a frota de veículos produzidos na década de 1980 atingisse $95 \%$ da produção nacional de veículos (CARVALHO, 2000 citado por CANÇADO, 2003).

\subsubsection{O cenário atual}

O Brasil produz atualmente 250 mil barris diários de etanol, proveniente de 2,7 milhões de hectares de área plantada com predominância no Estado de São Paulo. Este montante equivale a 3\% da produção de petróleo da Arábia Saudita ou ainda um quarto da produção do Iraque antes da guerra. Um processo de expansão foi iniciado em São Paulo com a pretensão de expandir a produção atual em 50\% até 2010 objetivando atender demandas do mercado internacional. Um fator relevante que motivou este incremento produtivo foi a produção mundial de automóveis tipo flexfuel ${ }^{2}$ (combustível flexível) iniciada em 2003 além de legislações em outros países permitindo adicionar álcool à gasolina, ou ainda aumentar a proporção de álcool à mistura com gasolina (GOLDEMBERG, 2005).

\footnotetext{
${ }^{2}$ Flexfuel é um termo utilizado para caracterizar automóveis que podem ser abastecidos tanto com álcool anidro como com gasolina.
} 
Até 2010 , estima-se que $70 \%$ dos veículos automotores produzidos no Brasil serão híbridos e utilizarão álcool como opção de abastecimento. Esta previsão exigirá um incremento de 7 bilhões de litros/ano somente para a demanda brasileira. $O$ movimento denominado "retomada do programa de álcool" apresenta alguns diferenciais em relação ao Próalcool na década de 1970. É fomentado pela iniciativa privada e ocorre em um momento que não há crise de abastecimento de gasolina. O usuário pode ter um carro híbrido e optar por gasolina ou álcool com preço mais acessível (INÁCIO, 2004).

Com olhos para tal incremento produtivo, as usinas de processamento de cana-de-açúcar em São Paulo estão buscando recursos para investir na produção através de participação junto ao mercado mundial de carbono estabelecido pelo protocolo de Kyoto, que entrou em vigor em 16 de fevereiro de 2005. Algumas usinas do interior paulista produzem energia limpa a partir do bagaço de canade-açúcar, com isso, podem desenvolver projetos de geração de certificados de redução de emissões pelo $\mathrm{MDL}^{3}$ (Mecanismo de Desenvolvimento Limpo). Estimativas apontam a geração de cerca de 4,8 mil dólares para cada mil toneladas anuais de créditos de carbono vendidos (Anonymus, 2005).

No entanto, outra abordagem do tema aponta para os problemas ambientais gerados pela queima de biomassa. Segundo o IPCC (Intergovernmental Panel on Climate Change ${ }^{4}$ ), o nível de emissão mundial de dióxido de carbono em 1990 era de 7,4 bilhões de toneladas/ano, sendo 6 bilhões provenientes do setor de energia, 1,2 bilhão resultante de queimadas e 0,2 bilhão da produção de cimento.

\footnotetext{
${ }^{3}$ O MDL é um mecanismo que prevê investimentos dos países com metas a cumprir na reformulação do modelo energético das nações pobres, para obter "créditos de carbono" (Folha de São Paulo, 2005).

4 Painel Intergovernamental sobre Mudança de Clima foi estabelecido em 1988 pelo PNUMA (Programa das Nações Unidas para o Meio Ambiente) e pela OMM (Organização Mundial de Meteorologia).
} 
Este mesmo órgão aponta que a concentração de $\mathrm{CO}_{2}$ na atmosfera evoluiu de 280 ppm (partes por milhão) em 1870 para 360 ppm na década de 1990 conforme apresenta o Gráfico 1.

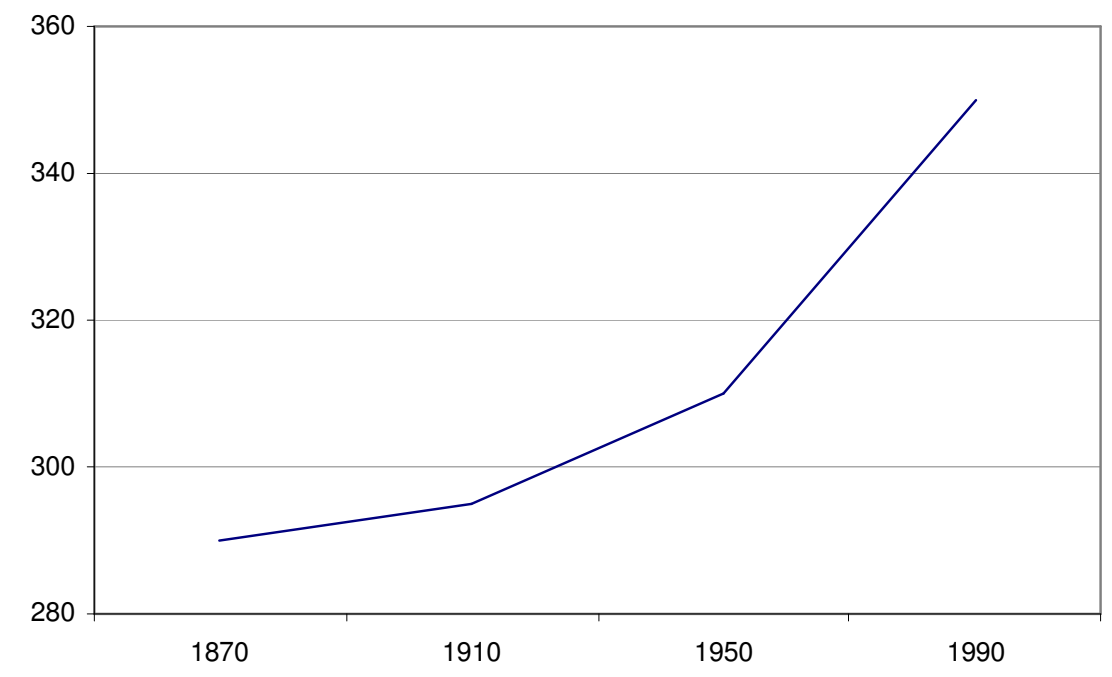

Gráfico 1: Evolução da concentração de $\mathrm{CO}_{2}$ (ppm) na atmosfera. Fonte: UNEP, IPCC, Nasa e Universidade de Washington. Adaptado de: [Anonymus], 2005.

Aumentar a produção de álcool pode ser bom para a economia, porém contribui para $\mathrm{o}$ aumento das concentrações de $\mathrm{CO}_{2}$ na atmosfera em função das queimadas que são adotadas como parte do processo de colheita da cana-de-açúcar. O aumento de concentrações impacta o clima afetando a dinâmica da circulação atmosférica e o ciclo da água, minimizando a precipitação de chuvas na região (ANDREAE et al., 2004). 


\subsubsection{Considerações sobre o tema}

Ao percorrer toda a bibliografia abordada objetivando a construção de uma linha histórica sobre a cana-de-açúcar desde suas origens até o momento atual com a expansão do agro-negócio canavieiro em São Paulo, poucas citações relacionadas ao tema saúde ambiental foram encontradas. Assim sendo, faz-se aqui necessário dissertar sobre algumas questões relevantes.

O primeiro ponto diz respeito à queima de biomassa e a conseqüente emissão de $\mathrm{CO}_{2}$ na atmosfera, contribuindo para o aquecimento global entre outros fatores. Apesar dos esforços de ambientalistas e organizações não governamentais e sociedade civil, tal questão torna-se menor em função do inevitável esgotamento de combustível fóssil predito para as próximas décadas. É sabido que o ato de reduzir a emissão de gases na atmosfera implica em mudanças econômicas, no entanto, observa-se empenho em desenvolver a economia com poucos olhos para a questão ambiental. Neste contexto, os créditos gerados via MDL contribuem para um melhor equilíbrio da relação entre economia e meio ambiente.

O segundo ponto aborda a questão da saúde das pessoas. Os efeitos deletérios à saúde humana das populações que habitam o entorno de áreas onde ocorre queima de biomassa é pouco conhecido ou pesquisado. A história pouco ou nada registrou a respeito de tal preocupação. Alguns relatos abordam a temática da destruição dos ecossistemas em detrimento ao plantio da cana-de-açúcar, no entanto os autores pesquisados sequer referenciam à saúde das coletividades envolvidas.

Mesmo a considerar longeva história, os capítulos mais recentes ocorridos no século XX somente apontam questões econômicas tais 
como o racionamento de açúcar ou as mudanças demográficas na década de 1940. A correlação entre problemas ambientais e saúde pública neste âmbito torna-se objeto de pesquisa somente nos tempos atuais, ainda que possa provocar problemas na ordem econômica dos agro-negócios.

O Estado de São Paulo, através da Secretaria de Estado do Meio Ambiente, estabeleceu prazos para a eliminação da colheita pelo método da queima da palha da cana-de-açúcar até 2031 pelo decreto no 47.700, de 11 de março de 2003. Entende-se que até lá as questões técnicas sobre plantio mecanizado em áreas com declividade acentuada estarão resolvidas. Porém outra questão surge deste contexto, são cerca de 1 milhão de trabalhadores que vivem do corte da cana no processo de colheita atual. A maioria sem qualquer outra qualificação serão futuros desempregados deste meio de vida.

Alguns trabalhos sugerem que o custo da colheita por corte manual é um diferencial que promove vantagens comerciais para o Brasil barateando o produto final. Se isso é verdade, a colheita mecanizada poderá alterar o equilíbrio da balança comercial negativamente para a economia brasileira. Se economicamente o cenário não é tão otimista, do ponto de vista da saúde pública e ambiental, será um avanço em prol da qualidade de vida das coletividades.

Com relação aos trabalhadores, o Brasil já viveu situação similar em 14 de maio de 1888, um dia após a assinatura da Lei Áurea, neste episódio, foram libertos 700 mil escravos sem nenhuma qualificação outra que não fosse o trato da cultura de cana-de-açúcar ou café. A diferença para o problema atual é o fato de haver tempo para equacionar o problema até 2031. 


\subsection{O AMBIENTE NO CONTEXTO DA SAÚDE PÚBLICA}

\subsubsection{A Saúde}

O caminho menos complexo para dissertar sobre saúde e ambiente provavelmente seja iniciar com a definição de tais termos e o contexto que estes se inserem no âmbito da saúde pública.

No que diz respeito à definição de saúde, talvez a mais conhecida seja aquela adotada pela OMS (Organização Mundial da Saúde) em 1946, definindo que "Saúde é um estado de completo bemestar físico, mental e social, e não apenas a ausência de doença ou enfermidade", contrapondo a definição "ausência de doença", mais simplista, esta incorpora ao tema, os aspectos sociais e ecológicos (COURA, 1992).

Por outro lado, COURA (1992) utiliza o exemplo de uma pessoa submetida ao ônibus lotado na região dos trópicos, ou mesmo um jovem que brigou com a namorada, não se enquadram no ponto "completo bem-estar físico, mental e social", lembrando que seria demasiado exagero considerá-los doentes por tais motivos.

Aprofundando-se na abordagem da influência do meio sobre a saúde das pessoas, outra linha de visão proposta por DUBOS (1961 citado por COSTA, 2002), coloca que o "estado de saúde ou doença são a expressão do sucesso ou fracasso experimentado pelo organismo no seu esforço de resposta adaptável aos desafios do meio ambiente." (DUBOS, 1961 citado por COSTA, 2002; p. 24). Observase neste ponto, a preocupação com a questão ambiental focada na adaptabilidade do indivíduo, ou seja, o organismo se empenha na 
adaptação ao ambiente que vive. Se for bem sucedido, alcança o bem estar físico, mental e social desejado.

Mais adiante, o mesmo DUBOS (1968 citado por COURA, 1992) afirma que "o homem é mais um produto do seu meio do que de sua herança genética" ou seja, "a saúde dos seres humanos não está determinada por suas raças, e sim pelas condições sob as quais vivem" (DUBOS, 1968 citado por COURA, 1992; p. 336).

AUDY (1971) coloca que "saúde é a propriedade contínua, potencialmente mensurável, da habilidade de um indivíduo reagir a insultos químicos, ou físicos, ou infecciosos, ou psicológicos, ou sociais" e dá a conotação métrica para as habilidades humanas de adaptação ao meio em que vive (AUDY, 1971 citado por RIBEIRO e ASSUNÇÃO, 2002).

Dentro do mesmo enfoque, LACAZ (1972) salienta que não se pode separar a existência da doença do substrato causal que a produz.

Nesta mesma linha, COURA (1992), afirma que independente da localização geográfica, nos trópicos ou nas mais elevadas latitudes, os seres vivos se adaptam ao meio em que vivem. Em especial os animais de sangue quente, dependem de uma série de adaptações físicas, fisiológicas, ecológicas e culturais, alterando o metabolismo, a estrutura e fisiologia da pele, a mobilidade ou plasticidade vascular e os mecanismos de centrais de regulação térmica. Ainda quando seu corpo não é capaz de suprir os limites naturais impostos, os animais lançam mão de recursos artificiais como roupas, abrigos, ventilação, etc. para garantir sua sobrevivência. 
Concluindo esta linha, FORATTINI (1992) quando descreve o homem moderno e sua interação e adaptação ao meio ambiente, deixa claro que este merece atenção especial em relação aos conceitos que permeiam sua existência, dentre eles, a qualidade de vida está entre os mais discutidos na atualidade.

O corpo humano é capaz de adaptar-se por meios genéticos, fisiológicos, comportamentais e culturais. A adaptabilidade diz respeito ao êxito ecológico e pode ser avaliada por meio de parâmetros demográficos, energéticos e nutricionais. Os parâmetros demográficos mais comuns utilizados são o equilíbrio entre natalidade e mortalidade, morbidade ou incidência de doenças e a taxa de reprodução da população. Os parâmetros energéticos indicam adequação de tecnologias. Já os parâmetros nutricionais, refletem conhecimento acerca de recursos, como a capacidade de explorá-los (MORAN, 1994).

Entre outros, o modelo LALONDE (1974), adotado pelo governo canadense na década de 70 , parte do princípio que os componentes espaço, fatores sociais, estilo de vida e bagagem genética estão intrinsecamente relacionados, compondo um bem social, uma construção coletiva. Tal visão de fatores intrínsecos foi consubstanciada na Conferência Mundial de Saúde realizada de 1986 em Otawa, no Canadá, e visou propor estratégias que incluísse, entre outros, cuidados ambientais e incentivos a iniciativas de responsabilidade pessoal na preservação de agravos e promoção de comportamentos e práticas saudáveis (MINAYO, 2002). 


\subsubsection{O Ambiente}

HIPÓCRATES, em seu conhecido trabalho "Ares, Águas e Lugares" já ponderava que, para estudar corretamente a ciência da medicina é necessário considerar os efeitos que pode produzir cada estação do ano, mudanças nos ventos e propriedades do solo e da água utilizada pela população em estudo. Sem conhecer o método científico, Hipócrates visualizou e difundiu em seu trabalho a importância do ambiente associada ao processo saúde-doença. Esta correlação, até hoje inquestionável, torna necessária uma explanação aprofundada sobre a abordagem ambiental na Saúde Pública, que forma a base do campo de estudos em Saúde Ambiental.

O termo "ambiente" pode ser definido como aquilo que cerca ou envolve os seres vivos. Sob este aspecto, vários enfoques já foram propostos com o intuito de explicar suas relações com a saúde. Portanto, ambiente é o lugar onde o cotidiano acontece e onde se realizam os padrões de qualidade de vida que determinada sociedade atinge. Na mesma linha, o termo "ecossistema é uma unidade ecológica fundamental relacionada às espécies associadas de organismos vivos em um ambiente físico abiótico e às relações estruturais e funcionais entre as mesmas" (MORAN, 1994; p. 28).

Em outras palavras, o ser humano habita um ambiente onde estabelece relações com outros seres vivos e se adapta sob diversos aspectos com a finalidade de obter êxito ecológico.

Vale ressaltar que o termo ecologia diz respeito ao estudo das relações entre os seres vivos e o meio em que vivem. BOOKCHIN (1980) advoga o termo ecologia porque propõe uma concepção mais ampla da natureza e da relação da humanidade com o mundo natural. No entanto, seguindo uma visão ecocêntrica, considera o equilíbrio e a 
integridade da biosfera como um fim em si mesmo, insistindo que o homem deve mostrar um respeito consciente pela espontaneidade do mundo natural. (DIEGUES, 1994).

Agregando a este raciocínio, entre as idéias principais que se baseia o "novo naturalismo", MOSCOVICI (1974) coloca que não é o indivíduo que se relaciona com a natureza e sim a coletividade. Nesta visão, a sociedade é parte e produto da natureza. Porém, com a aparição das cidades e dos estados a partir do Neolítico, a sociedade, assim como o pensamento e o saber, se construíram contra a natureza. Tal construção gerou divisão entre os homens e multiplicou proibições e interdições. A proposta do novo naturalismo sugere um estreitamento de vínculos entre homem e natureza através do intercâmbio de trabalho, linguagem, costumes, técnicas e ciências (MOSCOVICI, 1974 citado por DIEGUES, 1994).

Considerando a hipótese de que o homem se encontra em "equilíbrio dinâmico com o ambiente total, social e físico" (HUNTER, 1974 citado por RIBEIRO, 1988), subentende-se que qualquer alteração deste ambiente afetará tal equilíbrio, favorecendo novas doenças e padrões de saúde para aquela população que habita 0 espaço envolvido (RIBEIRO, 1988).

O equilíbrio dicotômico ser humano / meio ambiente, está inserido nas teorias do desenvolvimento. O termo "desenvolvimento" significa mudança, evolução, crescimento, metamorfose. Na qualidade de instrumento de trabalho das ciências sociais, o ponto de partida passa pela categorização de regiões do planeta como "atrasadas" ou subdesenvolvidas, no sentido de pobreza, fome, produto nacional baixo, baixa renda per capita e generalizando, baixos padrões de vida para grande parte da população. A solução para este quadro, 
principalmente entre as décadas de 1950 e 1970, resumia-se no termo desenvolvimento econômico. O modelo implícito ditava que o status de sociedade moderna, só poderia ser alcançado se os países em questão seguissem certas estratégias que vinham dos países industrializados. A ineficiência de tal abordagem ficou clara ainda na década de 1960. Nos últimos anos, a teoria do desenvolvimento deu espaço para uma abordagem alternativa que implica na estratégia voltada para as necessidades básicas do país, ou seja, uma visão endógena das questões voltadas para a coletividade, com respeito ao meio ambiente (STAVENHAGEN, 1985).

A economia mundial é um fator substancial nas questões de desenvolvimento. Neste contexto, MORIN e KERN (1993) descrevem sobre a oscilação da economia entre crise e não-crise, desregulamentos e re-regulações, para manter o valor monetário, muitas vezes promove destruições e estragos humanos, culturais, morais e sociais em cadeia. Ressaltam ainda que o crescimento econômico, ao mesmo tempo em que traz melhorias consideráveis ao nível de vida, provoca perturbações no modo de vida.

No mesmo momento em que a coletividade e o ambiente representam fatores de grande importância para as questões de saúde, também definem o objeto e os problemas da Saúde Pública. O ponto de equilíbrio talvez seja identificar quanto ou como o ser humano pode ou deve alterar o ambiente em que vive, sem seqüelas ao ecossistema. 


\subsubsection{A Saúde Pública}

Como fora anteriormente descrito, os agravos à saúde estão entre os problemas que comprometem a qualidade de vida humana. Tais agravos, quando tratados em caráter individual, são objeto de estudo da medicina "sensu latu". Porém, quando o foco passa a ser a coletividade, constituem o amplo campo da saúde pública (FORATTINI, 1995).

No que tange a questão qualidade de vida, FORATTINI (1992) aponta para a existência de 2 tipos de necessidades a serem satisfeitas: Concretas e Abstratas. A primeira, mais genérica, diz respeito a aspectos como moradia e alimentação. A segunda estaria ligada a aspectos como a auto-estima do ser humano.

Sobre a definição do tema, FORATTINI (1992) conceitua saúde pública como "a atividade social, cujo conceito implica em precipuamente o objetivo de promover e de preservar a saúde e, conseqüentemente, o bem-estar da população." (FORATTINI, 1992, p. 244).

As primeiras investigações sistemáticas no âmbito da saúde pública, bem como o conjunto articulado de proposições para intervenção subsidiadas por relações entre a saúde e condições de vida de uma população distinta, surgem nos séculos XVIII e XIX com o aparecimento da Medicina Social na Alemanha ainda não unificada, que desenvolveu uma prática médica estatal para a melhoria das condições de saúde da população. A França e a Inglaterra nesta época dispunham de registros de natalidade e mortalidade, porém estes eram meramente censitários (BOUSQUAT e COHN, 2004). Em 1828, Villermé mostrou uma correlação entre taxas de mortalidade e 
condições de vida de diferentes classes sociais na França (ROSEN, 1980).

FORATTINI (1995) também ressalta que as atividades no campo da saúde pública são caracteristicamente multidisciplinares, uma vez que os agravos à saúde podem ser sistematizados nas categorias físico-química, biológica e social, categorias essas que são passiveis de inter-relacionamento.

Em concordância, LEFF (2001) coloca que:

"A interdisciplinaridade é proclamada hoje em dia não só como método e prática para a produção de conhecimentos e para sua integração operativa na explicação e resolução dos cada vez mais complexos problemas do desenvolvimento, mas surge com a pretensão de promover intercâmbios teóricos entre as ciências e de fundar novos objetos científicos" (LEFF, 2001. p. 70).

A inter-relação entre tecnologia, ciência e sociedade promove o interesse pela interdisciplinaridade, fortalecido pela integração crescente da vida social, com processos técnicos ligados à produção e aos processos econômicos, políticos, sociais, culturais e espirituais (SMIRNOV,1982 citado por DIEGUES, 1995).

DIEGUES (1995) ressalta a distinção entre interdisciplinaridade e transdisciplinaridade, onde a primeira é um encontro de cooperação entre disciplinas, cada uma contribuindo com seus esquemas conceituais, e a segunda, forma-se um contrato entre diversas disciplinas, as quais adotam um único método de investigação, ou um mesmo paradigma e cita GUSDORF (1982) afirmando que "a 
interdisciplinaridade trata não somente de uma justaposição, mas um colocar em comum" e concluindo "o interesse não está nas interfaces ou nos limites mútuos entre disciplinas, mas no conhecimento dos limites".

Neste aspecto, observa-se a importância do trabalho em saúde pública agregando conhecimentos de várias áreas do saber humano, consolidando o campo de conhecimento.

"Esse entrelaçamento de informações levará ao entendimento do mecanismo gerador e sustentador da problemática que afeta a população" (FORATTINI, 1995. p. 85)

A interdisciplinaridade é tão antiga quanto a compartimentalização do saber humano, porém a sua prática tem-se demonstrado mais apta ao exercício somente na atualidade através das questões do desenvolvimento, da paz e do meio ambiente, entre outras (DIEGUES, 1995).

O conceito de saúde pública parte do princípio da ação coletiva tanto do Estado como da sociedade civil no sentido de melhorar a saúde das pessoas. Neste contexto, a OPAS (Organização Panamericana da Saúde) investiu em uma iniciativa continental denominada "La salud pública em las Américas" com o intuito de definir e criar indicadores para medir o que se denominou FESP (Funções Essenciais da Saúde Pública). Tais funções foram concebidas dentro da abrangência dos campos de ação da saúde pública: Saúde Ambiental, Saúde Ocupacional, Saúde Materno Infantil e Enfermidades Crônicas (MUÑOZ et al, 2000). 
Segundo PENHA (2003), são pressupostos que fazem parte da concepção e das ações em saúde pública:

- Caracteriza-se como campo de conhecimento científico, tecnológico e de práticas sociais;

- Caracteriza-se como campo interdisciplinar;

- Caracteriza-se por ter como problemas de investigação e intervenção as populações e coletividades;

- Caracteriza-se por transformar o conhecimento sanitário e ambiental em diretrizes e ações de natureza política e de caráter público;

- Caracteriza-se por construir seu campo de conhecimento e intervenção a partir das dimensões biológica, sociais, econômicas, culturais e política;

- Caracteriza-se por considerar como base de indagação investigativa as experiências e as práticas cotidianas humanas.

Cabe ainda ressaltar um ponto importante no trato da saúde pública denominado "Promoção da Saúde", que foi definido na I Conferência Mundial de Saúde de 1986, em Otawa como "um processo de capacitação da comunidade para atuar na melhoria da sua qualidade de vida e saúde, incluindo uma maior participação no controle deste processo". Isto amplia o cenário envolvendo a participação das coletividades na compreensão e trato dos 
determinantes que interferem diretamente sobre as mesmas (CHIESA, WESTPHAL e KASHIWAGI, 2002).

Conclusivamente entende-se saúde pública como um campo interdisciplinar com objetivo de promover a saúde das coletividades para garantir qualidade de vida ao ser humano em seu meio ecossistema. Campo este de extrema necessidade e relevância, em um cenário onde se procura diminuir taxas de morbi/mortalidade, aumentando a expectativa de vida e, conseqüentemente aumentando a taxa de crescimento populacional. Em 1800 havia 1 bilhão de humanos, atualmente somos 6 bilhões e as expectativas somam 10 bilhões em 2050 (MORIN e KERN, 1993). Sem a promoção da saúde e a melhoria da qualidade de vida das coletividades, será ainda mais precário viver em um ambiente com previsões de ultrapassagem dos limites de subsistência.

\subsubsection{A Saúde Ambiental}

No amplo campo de conhecimento da saúde pública, trabalhar as variáveis saúde e ambiente de forma dissociada, consiste em prática pouco ou nada recomendada desde os tempos de Hipócrates. Este raciocínio consolidou a área de Saúde Ambiental que abarca diversos saberes integrando a saúde das coletividades no contexto do meio em que vivem.

FORATTINI (1992) define saúde ambiental como sendo a "prática sanitária concernente às circunstâncias e condições do meio que sedia a vida humana, focalizando-Ihes a influência sobre a saúde e o bem-estar da população". Este escopo que associa o lugar às 
condições de vida, não difere da abordagem seguida pela OMS (Organização Mundial da Saúde), que define saúde ambiental como:

"Aqueles aspectos de saúde humana, doença e acidentes que são determinados ou influenciados por fatores do meio ambiente. Isso inclui o estudo, não só dos efeitos patológicos de vários agentes químicos, físicos e biológicos, bem como os efeitos, muitas vezes indiretos, do ambiente físico e social como um todo sobre a saúde e o bem-estar" (OMS, 1989).

Outra definição para o tema foi elaborada pelo Ministério da Saúde brasileiro, definindo saúde ambiental como:

"O campo de atuação da saúde pública que se ocupa das formas de vida, das substâncias e das condições em torno do ser humano, que podem exercer alguma influência sobre a saúde e o seu bem estar" (MS, 1999).

Concluindo, entende-se que a área de conhecimento da saúde pública que se ocupa das formas da vida, das substâncias e das condições em torno do homem que podem exercer alguma influência sobre a saúde e o bem-estar é o foco da saúde ambiental.

Ainda no aspecto conceitual, a correlação saúde e ambiente está legitimada no Brasil através da lei oㅜ 8.080 , de 19 de setembro de 1990 em seu artigo $3^{\circ}$ que menciona: 
"A saúde tem como fatores determinantes e condicionantes, entre outros, a alimentação, a moradia, o saneamento básico, o meio ambiente, o trabalho, a renda, a educação, o transporte, o lazer e o acesso aos bens e serviços essenciais; os estágios de saúde da população expressam a organização social e econômica do país" (BRASIL, 1990).

No entanto, o assunto meio ambiente, quando associado à saúde, torna-se complexo pela diversidade temática que envolve a área. Este aspecto promove a interdisciplinaridade como modelo resolutivo para melhorar a compreensão das questões focadas nas subáreas deste campo.

A oficina sobre indicadores de saúde ambiental realizada no IV Congresso Brasileiro de Epidemiologia, elencou as seguintes subáreas programáticas, descritas no projeto VISGISUS ${ }^{5}$ (GALVÃO, 1998):
a) Água para consumo humano
b) Controle dos fatores condicionantes do risco de transmissão de doenças endêmicas por vetores
c) Contaminantes ambientais
d) Qualidade do ar
e) Contaminação do solo
f) Desastres naturais e acidentes com produtos perigosos

Especialmente a subárea "Qualidade do Ar", objeto de interesse desta dissertação, apresenta certa dificuldade metodológica em função

\footnotetext{
${ }^{5}$ VIGISUS: Projeto de vigilância em saúde do SUS, financiado pelo Banco Interamericano de Desenvolvimento.
} 
da complexidade etiológica das doenças respiratórias. Diversos fatores como poluição do ar (clima, gases e partículas entre outros) e suas interações geram dificuldade na interpretação dos resultados das pesquisas (BARQUERA et al, 2002).

BARQUERA et al. (2002), em seu artigo, apresenta um quadro de desafios da pesquisa epidemiológica correlacionando poluição ambiental e doenças respiratórias:

\begin{tabular}{|l|l|}
\hline Problema & Descrição \\
\hline $\begin{array}{l}\text { Seleção da amostra e } \\
\text { validade externa }\end{array}$ & $\begin{array}{l}\text { As amostras devem ser representativas para o interesse } \\
\text { da população. Usualmente os desenhos de amostras } \\
\text { complexas são necessários e geralmente sua } \\
\text { extrapolação para outras populações não é possível. }\end{array}$ \\
\hline Complexidade etiológica & $\begin{array}{l}\text { Doenças respiratórias são relacionadas a fatores } \\
\text { multidimensionais. O desenho do estudo deve ponderar } \\
\text { peso adequado para cada fator e seu determinado efeito. }\end{array}$ \\
\hline $\begin{array}{l}\text { Complexidade das } \\
\text { interações }\end{array}$ & $\begin{array}{l}\text { Status socioeconômico, nível educacional assistência à } \\
\text { saúde e comportamento. A modelagem de tais } \\
\text { fenômenos é necessária. }\end{array}$ \\
\hline $\begin{array}{l}\text { Mudanças na plataforma } \\
\text { conceitual }\end{array}$ & $\begin{array}{l}\text { Fatores relevantes para um estudo podem não ser } \\
\text { importante em outro estudo. }\end{array}$ \\
\hline
\end{tabular}

Quadro 1 - Desafios comuns na pesquisa epidemiológica de poluentes ambientais e doenças respiratórias. Fonte: Adaptado de BARQUERA et al. (2002)

Não é novidade para a epidemiologia e para a bioestatística a importância das amostras, primeiro no sentido de validar os resultados obtidos, segundo para possibilitar a extrapolação dos resultados para outros grupos de susceptibilidade. No que tange a questão citada por BARQUERA et al. (2002), devido ao conjunto de variáveis que agregarão uma hipotética pesquisa neste âmbito, a possibilidade de extrapolação dos resultados para outras populações torna-se inviável. O ambiente não é exatamente o mesmo e a interação das comunidades com este, são diferenciadas devido a aspectos culturais, 
sócio-econômicos, etc. Portanto, resta a pesquisa em si que pode ser reaplicada em outros lugares possibilitando comparações de resultados e conseqüente observação de fenômenos comuns entre os estudos.

Vários estudos relacionados ao efeito dos elementos encontrados na atmosfera sobre a saúde das pessoas foram realizados no final dos anos 1980 e início dos anos 1990. Tais estudos epidemiológicos procuraram correlacionar a ocorrência de disfunções ou aumento de ingresso hospitalar com a concentração média de contaminantes na atmosfera local. Os guias sobre vigilância da qualidade do ar dão ênfase aos estudos desse tipo porque apresentam resposta direta a uma população com exposição real, apesar da inviabilidade de extrapolação dos resultados. Por outro lado, os estudos de exposição a contaminantes em ambiente controlado permitem aplicação dos resultados com maior facilidade (WHOa, 1999).

Com relação ao binômio causa/efeito, enquanto variável dependente dos estudos de qualidade do ar, diversos fatores climáticos e meteorológicos são citados como componentes de interação associados ás doenças respiratórias. A figura 2 apresenta os principais fatores que interagem com as doenças respiratórias crônicas. 


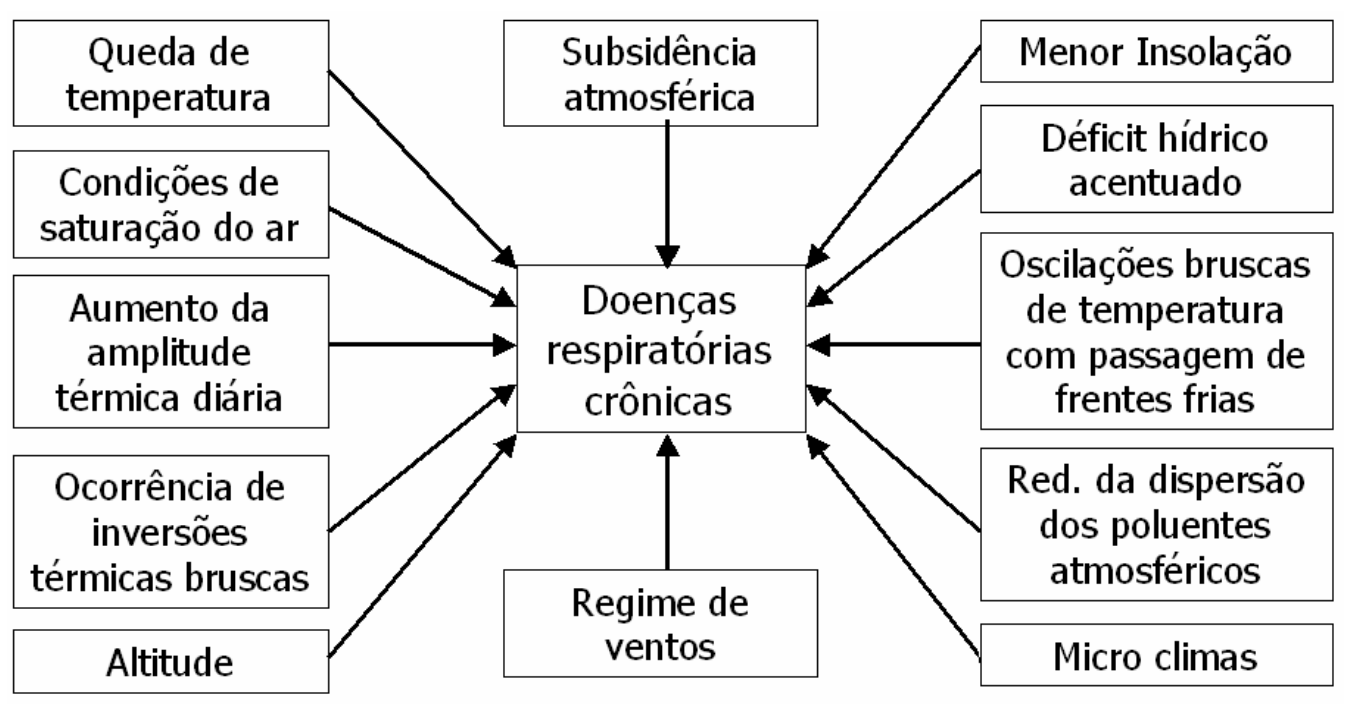

Figura 2: Principais componentes e interações entre fatores climáticos e meteorológicos e doenças respiratórias crônicas. Fonte: MIRANDA et. al, 1995.

Particularmente em estudos que envolvem queima de biomassa, fatores físicos como condições climáticas ou a meia vida biológica da partícula (que pode variar de dias a anos em razão da sua composição) são fundamentais para a construção de modelos de formação de plumas de dispersão dos compostos na atmosfera.

CASTRO, GOUVEIA e ESCAMILLA-CEJUDO (2003) colocam que a avaliação da exposição (AE) em estudos epidemiológicos possui um papel chave em pesquisas que correlacionam os efeitos da saúde em função da poluição do ar. Assim sendo, um processo de $A E$ iniciase com a identificação das fontes dos poluentes selecionados, para estudar a exposição do ser humano a um determinado poluente, afim de concluir se o indivíduo esteve em contato com uma dose biologicamente eficaz, ou seja, capaz de gerar um efeito adverso para um ser humano.

Porém, o problema torna-se mais complexo nesta relação causa/efeito porque depende de fatores como origem, composição 
química e tamanho da partícula, sem mencionar a diversidade existente na espécie humana. As alterações dos valores destas variáveis geram efeitos diferenciados na saúde humana (RIBEIRO e ASSUNÇÃO, 2002).

Portanto, além de considerar a presença de compostos químicos e material particulado em suspensão no ar, fatores como queda de temperatura, inversões térmicas ou regime de ventos devem participar como camadas de informação na composição de um cenário de estudo. Entretanto, tais elementos podem representar variáveis de confusão na interpretação dos dados levantados na pesquisa.

Tal complexidade multidisciplinar demanda saberes específicos e carece de esforços para a construção de conhecimento necessário nesta área da saúde pública.

\subsubsection{A Geografia Médica}

O espaço surgiu de forma mais sistemática no campo da saúde no século XVIII com a obra de Ludwig Finke, escrita em 1792, considerada um marco na geografia médica. Esta obra, inserida na corrente médica dos "sistematizadores", que buscavam uma causa única para a gênese das doenças, remetendo à concepção grega do processo saúde-doença. Porém antes do final do século, Finke e outros médicos mudaram o paradigma para o que chamaram de "empirismo neo-hipocrático", no qual afirmavam que só uma rigorosa observação do mundo poderia levar ao entendimento das causa das doenças (BOUSQUAT e COHN, 2004).

Finke é considerado o fundador da geografia médica. Sua obra é publicada no momento histórico em que se forma a Medicina Social 
anteriormente citada nesta dissertação. A Alemanha estruturou um sistema de supervisão de boticários, parteiras, cirurgiões e controle de qualidade das fontes de água. Esta prática foi denominada "Polícia Médica" e tentava identificar, a partir da observação, os fatores envolvidos na gênese das doenças. Este processo formalizou talvez 0 primeiro sistema de atenção médica (BOUSQUAT e COHN, 2004).

Neste momento histórico, a consolidação dos conceitos metodológicos, clínica, estatística e medicina social, dão o alicerce para surgir outro campo disciplinar específico denominado Epidemiologia (ALMEIDA FILHO e ROUQUAYROL, 2002).

A Epidemiologia, enquanto campo de conhecimento, tem formulado perguntas centradas nos três $\mathrm{W}$ na língua inglesa: Who, Where e When (quem, onde e quando), vinculando a importância do lugar em estudos desta disciplina. Considerando que a epidemiologia tem sido definida como "a ciência básica da saúde coletiva, que estuda o processo saúde-doença, sua distribuição e seus determinantes em grupos humanos" (ALMEIDA FILHO e ROUQUAYROL, 2002), é possível observar uma intersecção desta com a geografia médica e por sua vez com a saúde ambiental, no âmbito da saúde pública. Ou seja, o caráter interdisciplinar é notório nesta instância do conhecimento.

Isto posto, no intuito de estabelecer limiares para os campos disciplinares, a distribuição geográfica e ecologia das doenças seriam os objetos de estudo da geografia médica (RIBEIRO, 1988).

MEADE et al (1988 citado por BOUSQUAT e COHN, 2004) propõe que a geografia médica deveria responder as 6 perguntas e, daí derivar os estudos e delimitar o campo de conhecimento: 
a) Por que um fenômeno se distribui de um modo particular?

b) Por que as facilidades sociais e os investimentos sociais estão localizados onde estão, e não em outros lugares?

c) Por que as pessoas se movem em determinadas direções e por certas distâncias?

d) Por que as inovações se espalham de determinado modo?

e) Por que variam as percepções pessoais de espaço e meio ambiente?

f) Como objetos, idéias, processos e modos de vida interagem e se constituem em lugares?

Segundo MAYER (1984), os estudiosos da geografia médica têm desenvolvido 4 áreas de estudo:

1. A análise rigorosa dos padrões de distribuição espacial e temporal das doenças, usando técnicas e conceitos da Geografia Quantitativa e da Geo-estatística;

2. Mapeamento de doenças, incluindo o uso de mapas feitos por computadores que permitem, de modo mais rápido e seguro, a utilização de um maior número de dados.

3. Ecologia das doenças, usando conceitos de análise sistêmica, para entender padrões de causalidade das doenças dentro de diferentes contextos ambientais; 
4. A aplicação de conceitos geográficos ao planejamento para localização e administração de serviços de assistência médicohospitalar.

Outra abordagem, diz respeito aos aspectos técnicos. SORRE (1951 citado por RIBEIRO, 1988) ressalta a importância da cartografia, no que diz respeito à técnica de sobreposição de mapas exemplificando com cartas de situação climática associadas a cartas de distribuição de anofelinos, sobrepostos a cartas com dados epidêmicos de malária (RIBEIRO, 1988).

Considerando que o lugar onde vive uma população é um espaço socialmente construído, é possível indicar relações entre saúde e estrutura social, através da agregação de dados em mapas temáticos, na busca por homogeneidade dos dados distribuídos em uma área de estudo. Porém, a manipulação de grandes volumes de dados para associá-los a mapas, consiste em tarefa trabalhosa e de certa complexidade.

Nesta linha, BARCELLOS e BASTOS (1996) afirmam que as tecnologias disponíveis de geoprocessamento beneficiam trabalhos que buscam fixar um modelo de agregação de dados por unidade espacial.

Segundo MACGLASHAN (1972 citado por COSTA, 2002), a geografia médica desenvolveu-se mais recentemente em função da tecnologia. Cabe lembrar que os microcomputadores tornaram-se disponíveis para escritórios e residências a partir da década de 1980. Até então, o acesso a sistemas computacionais era restrito. Somente 
pesquisadores acadêmicos e grandes corporações possuíam computadores, ainda sim, com limitados recursos gráficos.

Atualmente um computador portátil é capaz de trabalhar bancos de dados com volumes na ordem de Giga bytes (bilhões de bytes) e manipular diversas bases cartográficas digitais. Ainda há que se considerar o advento da WWW (World Wide Web) na década de 1990, que permitiu disponibilizar diversos conteúdos de dados já prontos para uso em estudos. Estes fatores permitiram maior flexibilidade e agilidade no trato de dados para estudos epidemiológicos, entre outros.

Concluindo, a epidemiologia aliada à geografia, juntamente com poderosas ferramentas de informática capazes de associar bancos de dados a mapas, constituem um instrumental de trabalho de grande utilidade para estudos em saúde ambiental.

\subsubsection{Considerações sobre o tema}

Há muito que se pesquisar com relação à correlação causa/efeito entre os problemas ambientais e os efeitos deletérios à saúde humana. Os estudos ecológicos, por serem direcionados a uma coletividade, e não a um indivíduo, não são determinísticos, porém

geram subsídios para estudos mais aprofundados e consequentemente, mais onerosos. Nesta abordagem, as ferramentas que a geografia médica disponibiliza ao pesquisador, consistem em um valioso recurso fomentador de hipóteses para o desenho de estudos em saúde pública. 
Aliada à geografia médica, as ferramentas de geoprocessamento facilitaram o trato de grandes volumes de dados minimizando o trabalho do pesquisador que, desta forma, ganha flexibilidade e tempo para desenvolver tarefas mais importantes da pesquisa no âmbito da avaliação dos dados coletados.

Por demandar necessidades que envolvem profissionais de várias áreas do conhecimento humano, a saúde ambiental é um campo complexo que ainda carece de muita pesquisa para responder as várias perguntas ainda em aberto nesta busca por qualidade de vida para o ser humano. 


\subsection{O GEOPROCESSAMENTO NA SAÚDE AMBIENTAL}

\subsubsection{Definições}

A computação enquanto ciência estabelece interseções entre as diversas áreas do conhecimento humano na medida em que aperfeiçoa a capacidade de armazenar e processar dados provenientes de diversas fontes do mundo real.

Desde a década de 60, a informática vem evoluindo no sentido de prover o instrumental necessário para relacionar dados não gráficos e componentes gráficos, através da construção de cartas temáticas que possibilitam estudos de distribuição de temas em um determinado espaço. Dados não gráficos descrevem fatos e fenômenos do mundo real de maneira espacial, temporal ou temática. Componentes gráficos são objetos que representam entidades do mundo real em um plano gráfico.

No campo da saúde, a epidemiologia é a ciência que estuda a distribuição e os determinantes dos problemas de saúde das populações humanas.

ROUQUAYROL (1993) define o termo "Distribuição" em epidemiologia como o estudo da variabilidade da freqüência das doenças ao nível coletivo, em função de variáveis ligadas ao tempo, ao espaço, sejam elas ambientais, populacionais ou à pessoa.

O espaço é definido por SANTOS (2002), como sendo um conjunto de fixos e fluxos, onde os fixos são elementos que, fixados em cada lugar, permitem ações que modificam o próprio lugar. Os 
fluxos podem ser novos ou renovados que recriam as condições ambientais/sociais e redefinem o lugar.

Nesta linha de raciocínio, há uma relação entre a distribuição dos agravos de saúde e o espaço onde eles ocorrem, da mesma forma que a epidemiologia e a cartografia sempre estiveram interrelacionadas. A construção de mapas contendo dados de saúde permite observar fenômenos que nem sempre são possíveis de identificar com dados dispostos em tabelas. O significado que 0 homem atribui a um dado, por meio de convenções e representações, é convertido em informação que pode subsidiar uma decisão e conseqüente desencadeamento de ações.

As facilidades promovidas com a implementação de tecnologias computacionais abrem um universo de possibilidades para a pesquisa que até antes desse advento, passavam longe do instrumental disponível aos pesquisadores. Estas facilidades estão disponíveis através de um conjunto de recursos denominado Geoprocessamento que engloba vários assuntos como: cartografia digital, sensoriamento remoto, estatística espacial e sistemas de informação geográfica.

CÂMARA (2001), define que:

"O termo Geoprocessamento denota a disciplina do
conhecimento que utiliza técnicas matemáticas e
computacionais para o tratamento da informação
geográfica e que vem influenciando de maneira
crescente as áreas de Cartografia, Análise de
Recursos Naturais, Transportes, Comunicações,
Energia e Planejamento Urbano e Regional".
(CAMARA, 2001; p. 1)


A cartografia digital consiste em uma técnica para produção de mapas através de sistemas computacionais, onde os elementos que compõem determinada carta são convertidos em pontos, linhas ou polígonos em um plano cartesiano com posições geograficamente referenciadas (geo-referenciadas). Geo-referenciamento é a operação usada para relacionar registros tabulares a um lugar da superfície da terra. Para que sejam dispostos em mapas, cada um dos dados deve ser referenciado a uma unidade de análise geográfica.

A digitalização (criação dos objetos) pode ser feita de algumas formas: obtendo-se elementos a partir de um mapa já existente, tomando como base levantamentos de campo utilizando aparelhos de GPS (Global Positioning System) que fornecem as coordenadas latitude e longitude de um ponto selecionado, através da vetorização de fotos aéreas ou imagens de satélite, ou ainda integrando estes recursos em um único trabalho.

O sensoriamento remoto pode ser definido como o conjunto de atividades utilizadas para obter informações a respeito dos recursos naturais, através de sensores de radiação eletromagnética, colocados em aviões ou satélites (MOREIRA, 2001). O material produzido por estes sensores são fotografias de uma área em estudo, com nível de detalhe variando em função da precisão do instrumento, ou seja, o detalhamento possível de uma fotografia aérea varia em função da resolução - área do local coberta por um pixel (ponto referente à menor quantidade de informação da imagem). 
Uma vez construídos os mapas digitais e a eles, estabelecida associação com os dados não gráficos, é possível utilizar técnicas de estatística espacial que consiste em teste e cálculos para avaliar padrões espaciais.

Para manter os dados coletados (gráficos e não gráficos) adequadamente organizados, é necessária a utilização de sistemas de informação geográfica (SIG) que são softwares que possuem recursos para armazenamento de dados relacionados a localizações espaciais, que oferecem suporte suficiente para consultas e indexações com base nessas localizações espaciais (SILBERSCHATZ et al, 1999). A figura 3 apresenta a estrutura geral de um SIG identificando 0 relacionamento entre os principais componentes ou sub-sistemas. A implementação destes módulos pode ser distinta em cada SIG construído, mas para ser um SIG completo, todos os módulos descritos devem estar presentes.

A utilização do geoprocessamento em saúde pública é mais um caso de junção de dados e técnicas de áreas distintas, com o intuito de "visualizar" informação através de novas abordagens. De um lado o SUS (sistema Único de Saúde), constrói e mantêm volumosas bases de dados de saúde contendo informações sobre natalidade, internações, morbidade e mortalidade. Do outro lado, a geografia contribui para o mapeamento de todo o território nacional construindo cartas em escala regional ou local. Um SIG é capaz de unir dados de saúde dispondo-os em mapas, possibilitando uma nova visão da informação a partir da abordagem espacial. 


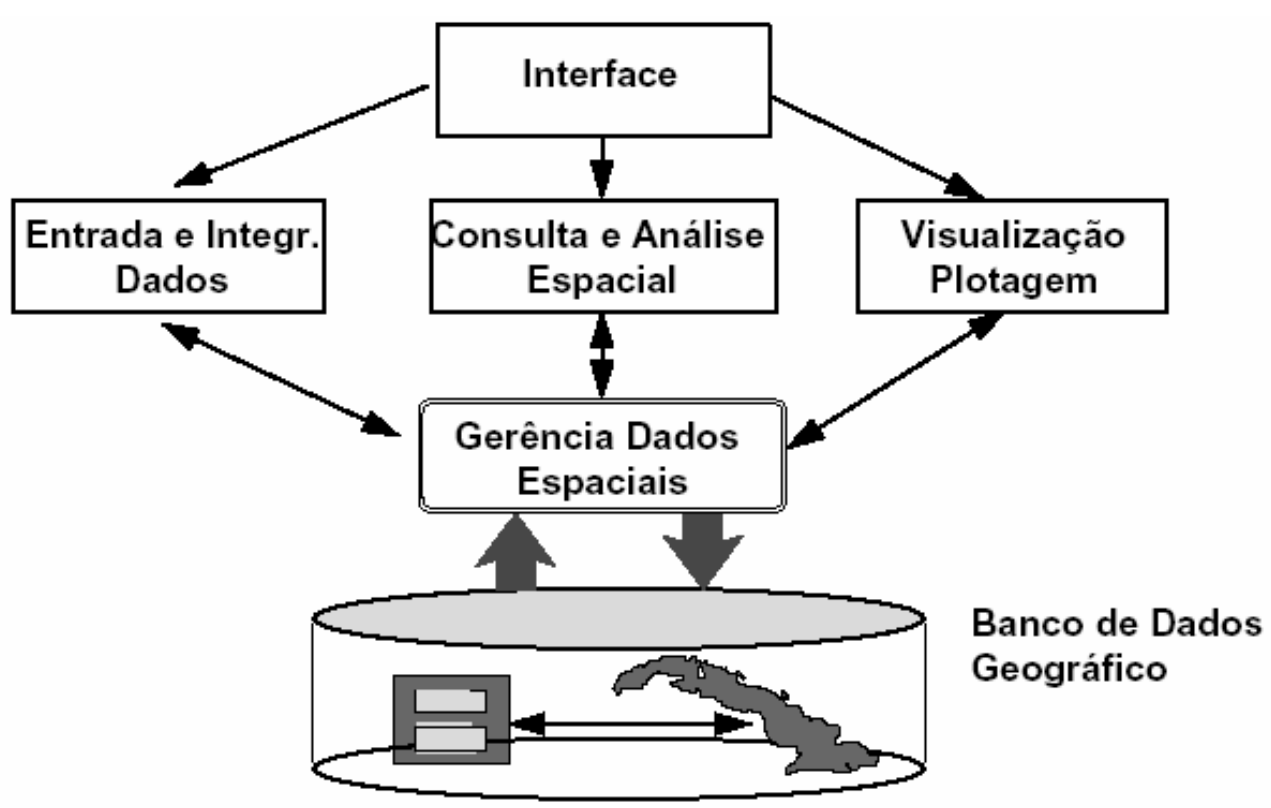

Figura 3 - Estrutura geral de um Sistema de Informação Geográfica.

Fonte: CAMARA, 2001.

O geoprocessamento através dos SIG's constituem ferramentas com potencial para análise epidemiológica na descrição da magnitude dos problemas de saúde, para a identificação de determinantes específicos e para apoio à tomada de decisões sobre intervenções apropriadas do setor saúde ou intersetoriais".

Para compreender a importância da utilização do geoprocessamento em estudos epidemiológicos de saúde pública é necessário conhecer o ganho obtido através dos produtos provindos da tecnologia SIG (Sistema de Informação Geográfica).

\subsubsection{Origens}

As questões de saúde associadas a uma referência geográfica são antigas. Em 1757 o médico escocês James Lind buscava estas 
correlações e publicou o livro "An essay on Diseases Incidental to Europeans in Hot Climates". Famoso por sua contribuição relacionada ao escorbuto, neste trabalho, o cirurgião naval procurava explicações para a distribuição de doenças e chegou a correlacionar doenças com áreas geográficas específicas.

O primeiro trabalho que pode ser considerado um SIG foi elaborado em 1838, para a construção da Estrada de Ferro Irlandesa. Consiste em um relatório contendo uma série de mapas com contexto populacional, fluxo de tráfego, geologia e topografia entre outros temas para todo o percurso da ferrovia.

Em 1855, John Snow, um médico anestesiologista inglês, publicou o trabalho "Mode of Communication of Cholera" onde utilizou - método epidemiológico associado aos mapas de Londres para comprovar que o cólera não era transmitido por eflúvios e sim era veiculado através do abastecimento inadequado de água, conforme apresenta o Mapa 2.

Na era da informática, os primeiros SIG's surgiram na década de 1960 no Canadá com a finalidade de desenvolver um inventário de recursos naturais. Nesta época, os recursos computacionais eram excessivamente caros e não dispunham de resolução satisfatória nas saídas do sistema (vídeo e impressora). Outros fatores oneravam a qualidade dos produtos gerados pelos SIG's, como tempo de resposta dos processadores e quantidade de espaço para armazenamento de dados, além da falta de especialistas para operar estes sistemas. 


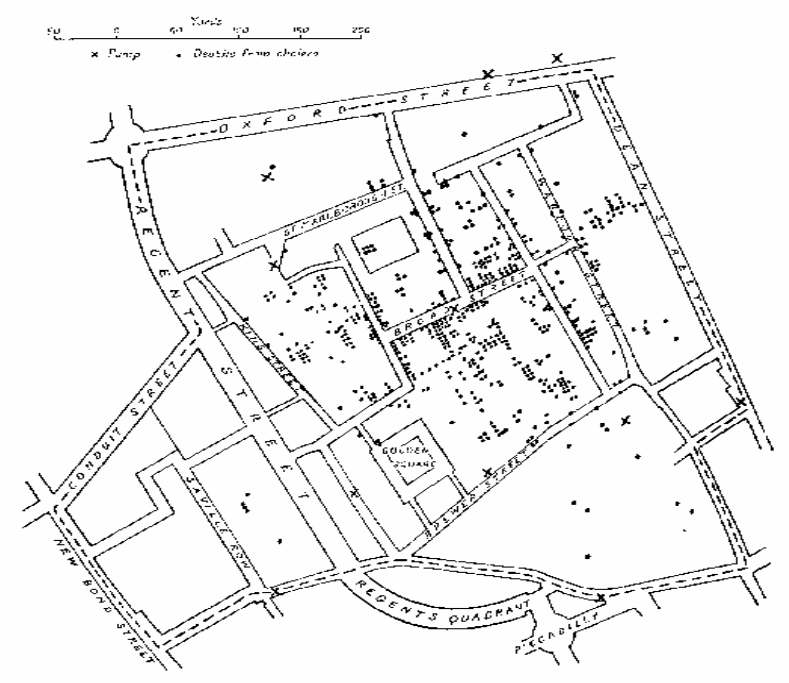

Mapa 2 - Óbitos por cólera em Broad Street e arredores (Londres, 1854).

Fonte: SNOW, 1999.

A década de 1970 contou com melhores recursos de hardware e impulsionados por um novo tipo de software, o CAD (Computer Aided Design). A expressão Geographical information System surgiu nesta época, além do desenvolvimento de alguns fundamentos matemáticos voltados para a cartografia, incluindo as questões de geometria computacional (CÂMARA, 2001).

Os anos 1980 foram marcantes na história da computação devido a disponibilização do microcomputador em larga escala além do crescente aumento da capacidade de processamento e armazenamento de dados. Este fato possibilitou a popularização do computador em larga escala como ferramenta de armazenamento e processamento de dados. Já a década de 1990 é marcada pela chegada da WWW (World Wide Web) que se tornou a maior fonte de acesso a dados disponível no mundo. 
Até os dias de hoje, os SIG's são limitados pela capacidade de processamento das máquinas disponíveis. A indústria de software cresce mais rápido que a industria de hardware, impondo o ritmo do avanço neste campo.

\subsubsection{O SIG e a Saúde Pública}

Os sistemas de informação geográfica podem gerar avanços fundamentais no entendimento das relações entre a saúde dos humanos e o meio ambiente. Uma ferramenta SIG pode ser utilizada para gerar mapas temáticos abordando a distribuição de doenças em um determinado lugar e o pesquisador poderá identificar padrões espaciais com o objetivo de gerar e testar hipóteses epidemiológicas (JACQUEZ, 1998).

Considerando que os dados espaciais de saúde e ambiente são tipicamente observacionais, geralmente agregam grandes volumes de dados dificultando sua manipulação e propiciam o aparecimento de variáveis que geram fatores de confusão, JACQUEZ (1998) apresenta em seu estudo, uma abordagem sistemática para análise espacial, representada no diagrama da figura 4 .

Os quadros "Disease data" e "Contextual data" representam o conjunto de variáveis do estudo. Elas comporão o mapa temático do estudo correlacionando doença e meio ambiente. 


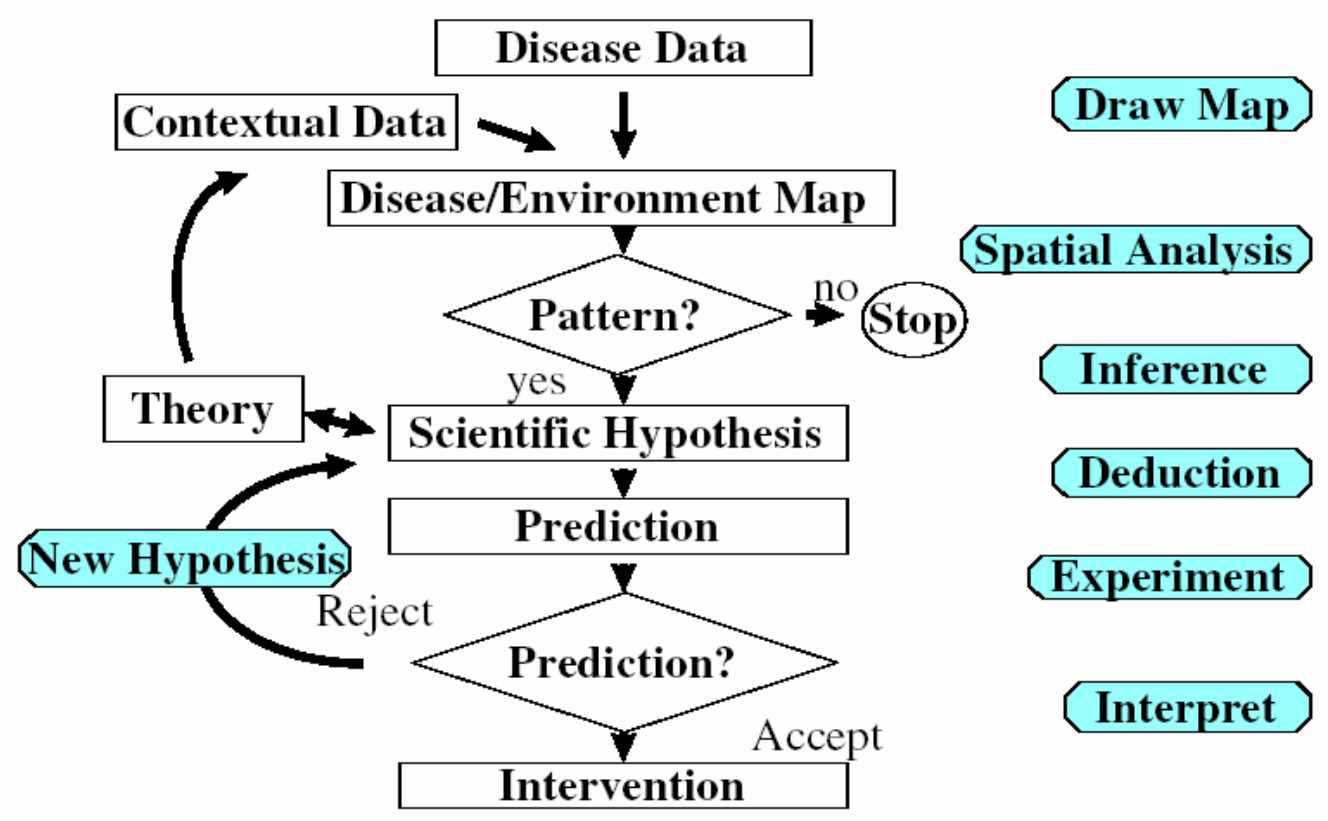

Figura 4 - Análise espacial em Saúde Pública, uma abordagem sistemática para análise espacial de dados de doenças. Fonte: JACQUEZ, 1999.

A construção dos mapas pode envolver técnicas de geoprocessamento tais como operações booleanas, buffering, interpolação, entre outras. A inspeção dos mapas possibilita a visualização de padrões que serão estatisticamente avaliados.

A decisão sobre se há padrão com significância para uma hipótese, dependerá do conhecimento do pesquisador sobre 0 contexto do estudo e não só dos resultados estatísticos. É possível encontrar padrões com significância estatística que não são de interesse da saúde pública. O inverso também pode ser verdadeiro, ou seja, não se encontrou relevância estatística para um padrão, porém outras razões levaram o pesquisador a prosseguir com o estudo. A predição deve ser deduzida da hipótese e pode então ser testada com um novo desenho de SIG. Se o novo estudo comprovar a predição, 
medidas de intervenção devem ser tomadas para reduzir o risco à população envolvida (JACQUEZ, 1998).

\subsubsection{Exemplos de Aplicações}

Muito já se fez com relação a Geoprocessamento no campo da saúde. Aplicações em SIG têm se destacado nas seguintes áreas: Vigilância Epidemiológica, Avaliação de Serviços de Saúde e Urbanização e Ambiente. Na Vigilância Epidemiológica, há estudos envolvendo o mapeamento de indicadores de saúde delimitando áreas de risco, além de estudos de exposição a agentes específicos. Com relação a serviços de saúde, são elaborados estudos de distribuição espacial de serviços de saúde com a finalidade de planejamento e otimização de recursos. Os estudos urbanos envolvendo variáveis como condições de moradia, emprego, pobreza, etc. procuram mostrar que problemas como poluição, superpopulação, estresse e pobreza afetam a saúde humana nas cidades.

A seqüência deste capítulo apresenta uma série de trabalhos desenvolvidos com tecnologia de geoprocessamento, no intuito de expressar as possibilidades tecnológicas que as ferramentas proporcionam ao usuário de SIG. 
Exemplo 1: Leishmaniose visceral americana em Araçatuba, São Paulo: O Mapa 3 mostra áreas com porcentagem de domicílios positivos e o número de exemplares capturados, apresentando certa correlação entre lugar e agravo.

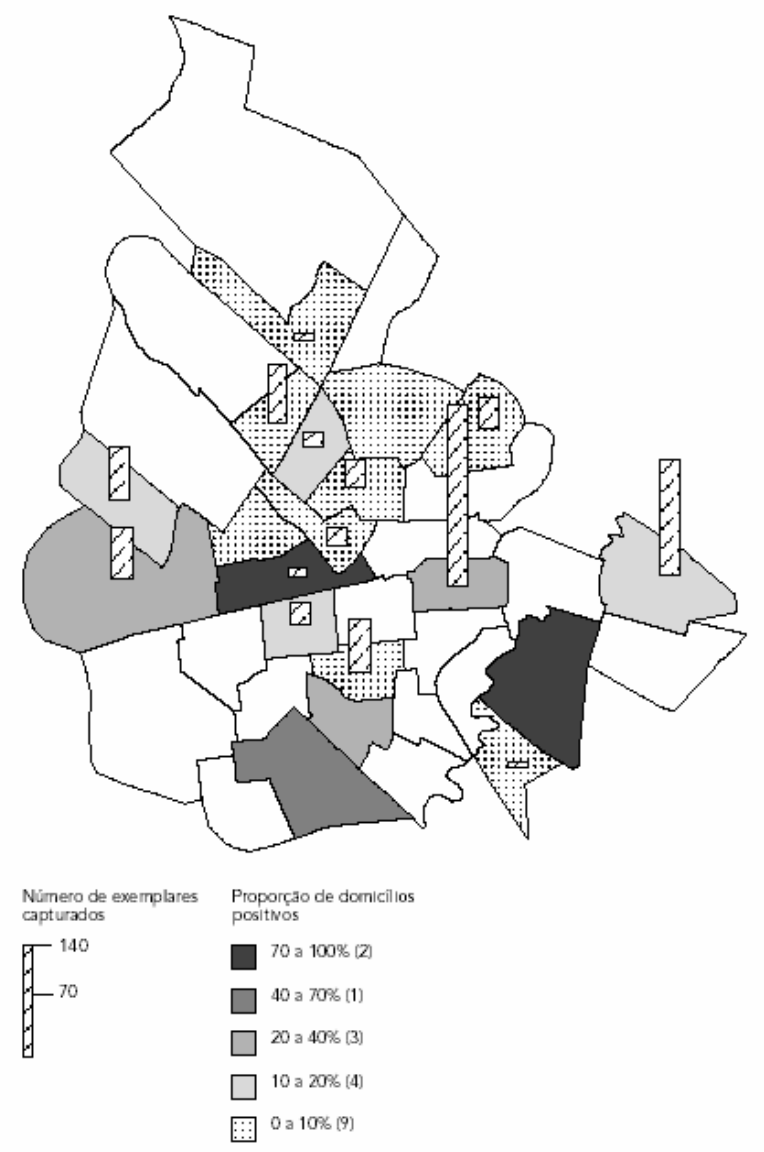

Mapa 3 - Distribuição da proporção de domicílios positivos para a presença de Lutzomyia longipalpis e do número de exemplares capturados em Araçatuba, São Paulo, 1998 - 1999. Fonte: CAMARGO-NEVES, et al., 2001.

Exemplo 2: Monitoramento da temperatura das águas oceânicas na baía de Piraquara de Fora - Angra dos Reis nos períodos de funcionamento da usina nuclear Angra I. Os sensores de temperatura posicionados na baia foram georreferenciados como apresenta o Mapa 4. 


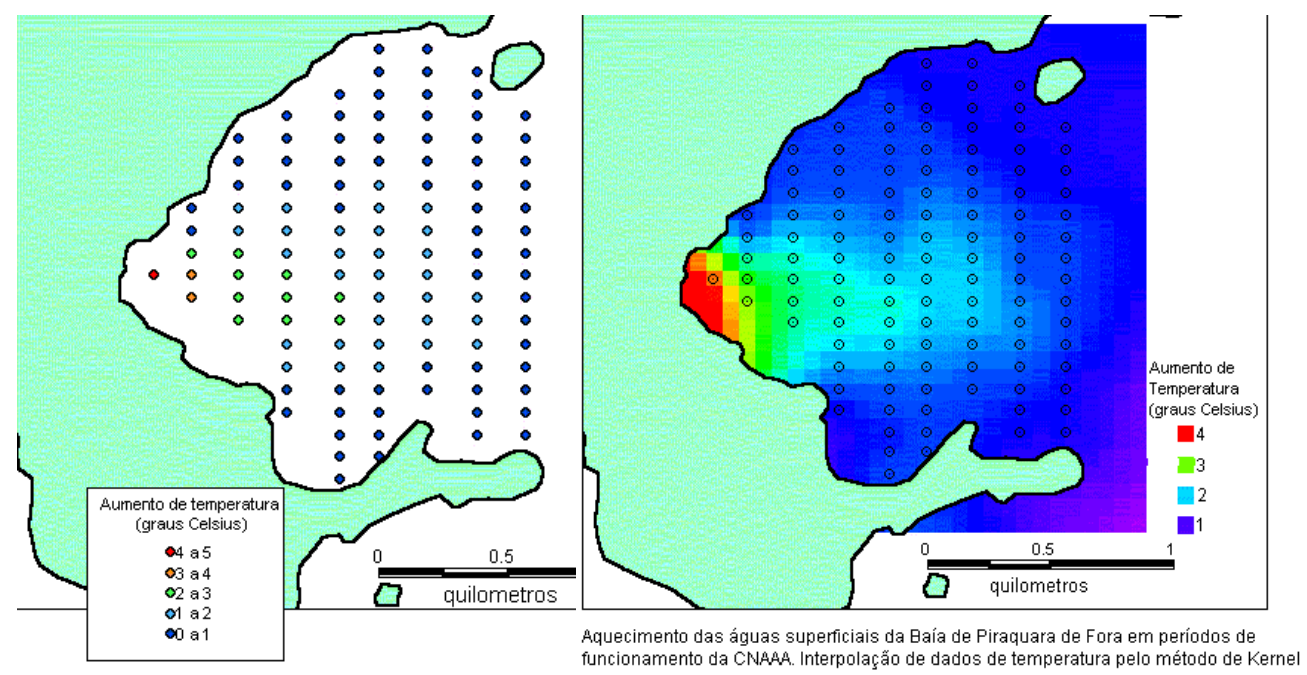

Mapa 4 - Monitoramento do aquecimento das águas oceânicas em Piraquara de Fora - RJ. Fonte: Barcellos, 2000.

Exemplo 3: Identificação das áreas de risco de homicídios em Porto Alegre - RS. Pela densidade dos eventos, pode-se mapear áreas de risco, como mostra o Mapa 5.

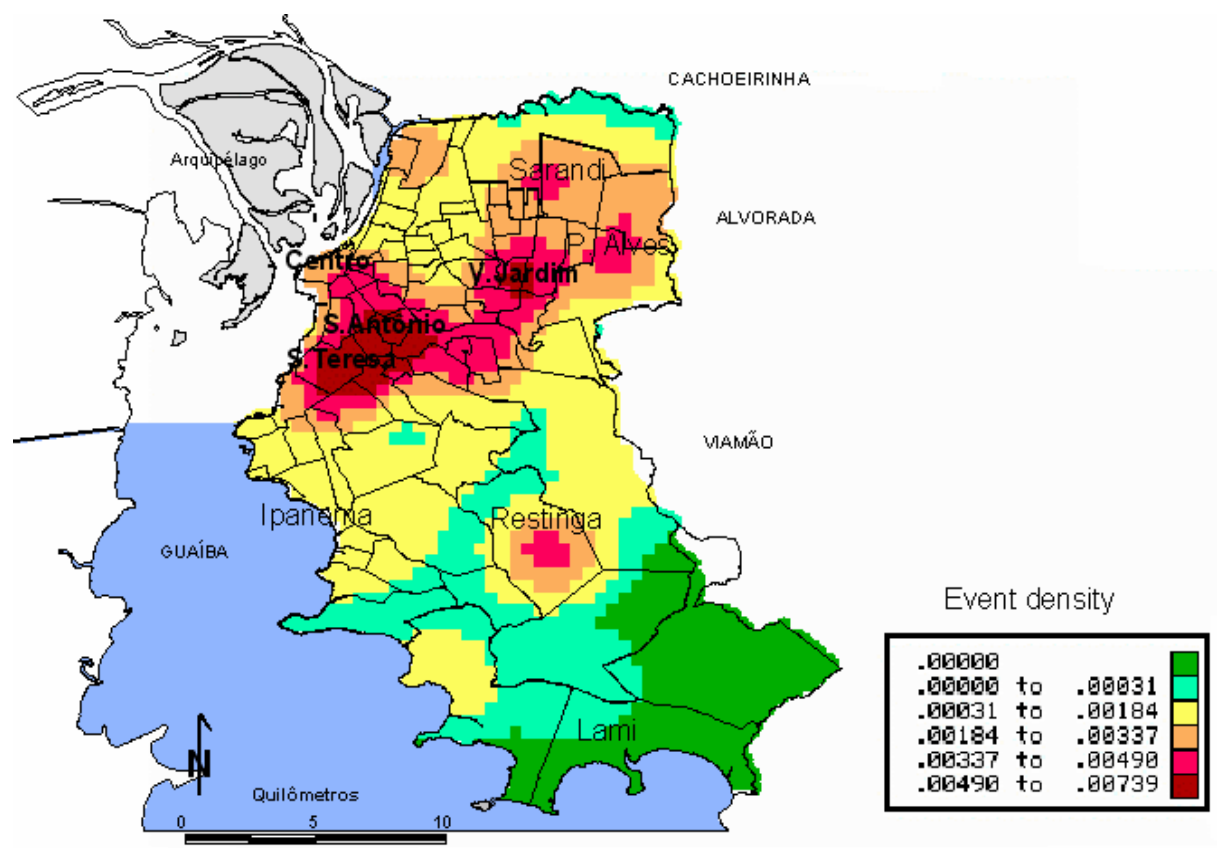

Mapa 5 - Distribuição da densidade de residências de vítimas de homicídio, Porto Alegre, 1996. Fonte: Santos, 2001. 
Exemplo 4: Fluxo de locomoção dos índios Kaiangang em busca de assistência do SUS no Rio Grande do Sul. O Mapa 6 apresenta o local das aldeias e o fluxo de locomoção dos índios até os centros de atendimento do SUS.

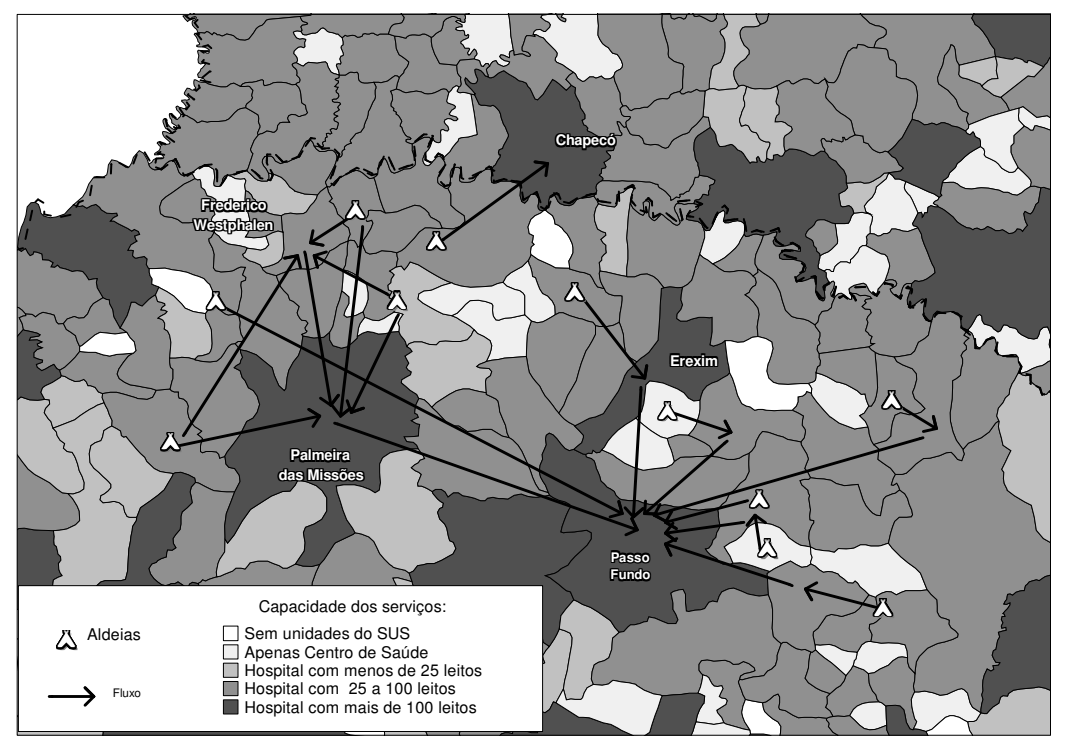

Mapa 6 - Fluxo de Índios Kaingang em busca de assistência do SUS. Fonte: Barcellos, 2000.

Exemplo 5: Identificação das áreas com coeficiente de mortalidade infantil elevado em Belo Horizonte - MG. Pela densidade dos eventos, pode-se mapear áreas de risco. O Mapa 7 apresenta os polígonos classificados por tons de cinza, indicando as áreas com coeficiente mais elevado.

Exemplo 6: Estudo de exposição à partículas inaláveis $\left(\mathrm{PM}_{10}\right)$ na região metropolitana da Cidade do México. O Mapa 8 foi elaborado a partir das médias anuais obtidas pelas estações de medição. As manchas permitem estimar a população exposta. 


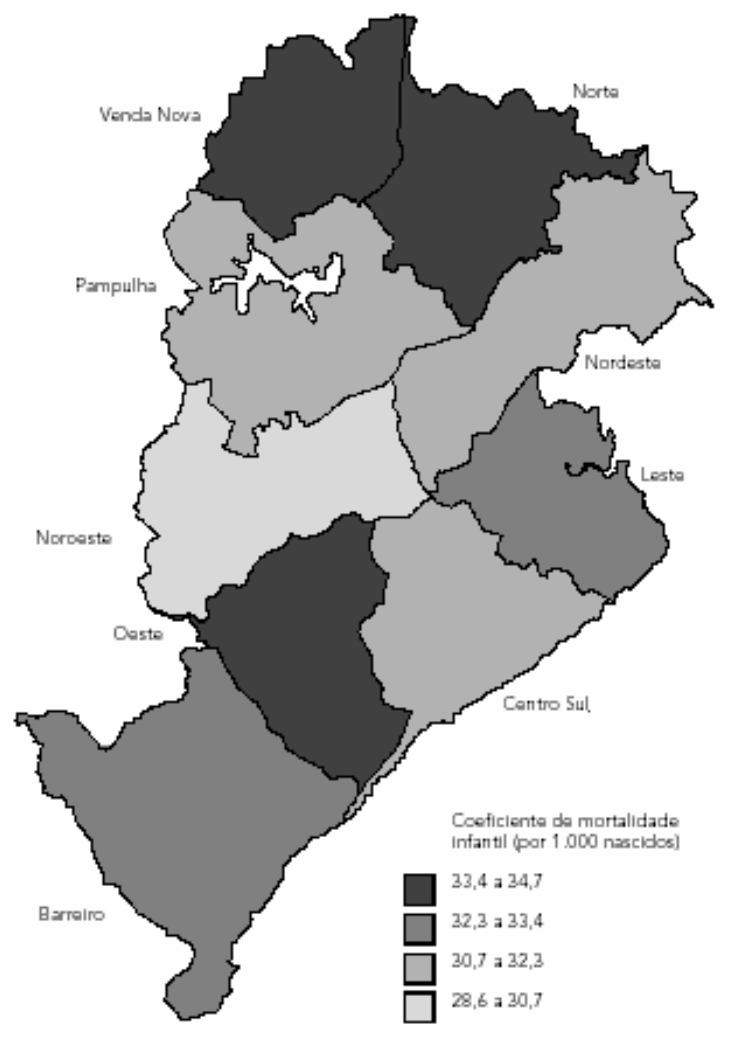

Mapa 7 - Coeficiente de Mortalidade Infantil, por Distrito Sanitário em Belo Horizonte, 1994. Fonte: MALTA et al, 2001.
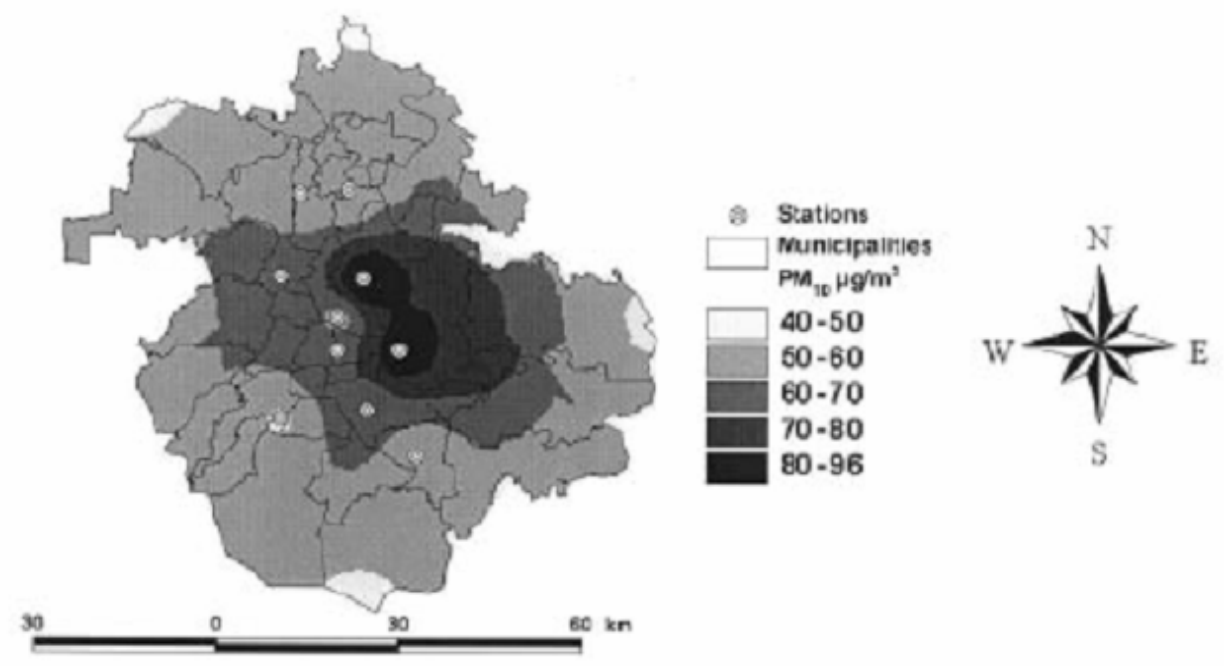

Mapa 8 - Medições de concentração média anual de $\mathrm{PM}_{10}$ na região metropolitana da Cidade do México (2000) Fonte: CICERO-FERNANDEZ et al, 2001. 
Exemplo 7: Estudo de exposição à partículas inaláveis $\left(\mathrm{PM}_{10}\right)$ no município de São Paulo. Os mapas 9 e 10 comparam as médias anuais em 1995 e 2000, mostrando melhoria da qualidade do ar na região central.

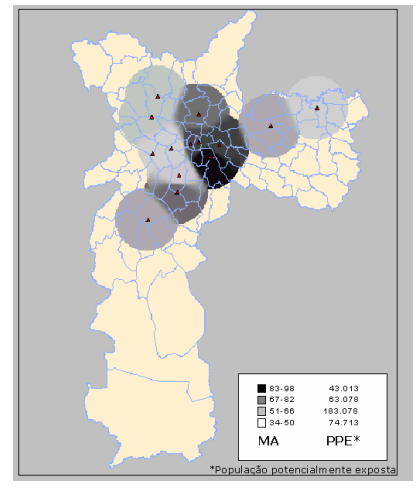

Mapa 9 - Medições de concentração média anual de $\mathrm{PM}_{10}$ e população potencialmente exposta, no município de São Paulo, São Paulo, 1995. Fonte: GOUVEIA, et al., 2003.

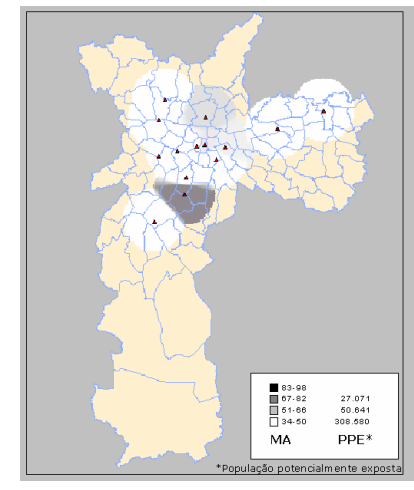

Mapa 10 - Medições de concentração média anual de $\mathrm{PM}_{10}$ e população potencialmente exposta, no município de São Paulo, São Paulo, 2000. Fonte: GOUVEIA, et al., 2003.

\subsubsection{Considerações sobre o tema}

Dois fatores contribuem para o crescente uso do Geoprocessamento em saúde. Por um lado, a necessidade de se estabelecer correlações entre as questões tratadas pela saúde e o espaço onde elas ocorrem. Por outro lado, o aumento contínuo do acesso aos recursos computacionais, com custo cada vez mais reduzido contrapondo a capacidade computacional cada vez mais elevada. 
Outro fator importante a ser levado em consideração é a possibilidade de se trabalhar com informações de diferentes origens e formatos. O campo da saúde conta com várias bases de dados sobre assuntos diversos como nascidos vivos, morbidade, mortalidade, internações, etc. Estas bases encontram-se disponíveis em formatos diversos (MS-Access, dBase, MS-Excel, Oracle, etc.) e os softwares disponíveis hoje permitem intercâmbio de dados entre estas bases. $O$ problema está em obter profissionais de informática com perfil para manipular estes dados. Apesar das facilidades disponíveis nos últimos anos, ainda são poucos os profissionais de informática interessados pelo assunto Geoprocessamento.

Os trabalhos resultantes nesta área de geoprocessamento são de considerável relevância para a saúde, porém demandam tempo e dedicação para sua elaboração. 


\section{METODOLOGIA}

\subsection{Delineamento Geral:}

Para buscar uma correlação entre incidência de doenças respiratórias crônicas e exposição aos produtos da queima de palha de cana-de-açúcar, optou-se por um estudo epidemiológico ecológico devido à abordagem que se pretende, muito similar à própria definição conforme escreve ALMEIDA FILHO e ROUQUAYROL, 2002:

"Os estudos ecológicos abordam áreas geográficas ou blocos de populações bem delimitados, analisando comparativamente variáveis globais, quase sempre por meio de correlação entre indicadores de condição de vida e indicadores de situação de saúde" (ALMEIDA FILHO e ROUQUAYROL 2002, p. 174).

$\mathrm{Na}$ mesma linha, CASTRO (2003) define que nos estudos ecológicos a unidade de análise não é o indivíduo, mas sim um grupo de indivíduos, ou seja, os dados disponíveis no estudo dizem respeito a um agregado de indivíduos. Com efeito, a análise baseia-se na comparação dos indicadores de exposição à poluição do ar e doenças entre as unidades (CASTRO et al., 2003).

As doenças respiratórias crônicas são as variáveis dependentes ou o efeito presumido do estudo. Sabe-se que no período de inverno a incidência de doenças respiratórias aumenta no Estado de São Paulo, devido às condições climáticas que a estação proporciona, como clima seco ou a ocorrência de inversões térmicas bruscas. Este quadro influi 
diretamente no aumento da procura por serviços de saúde com o intuito de remediar diagnósticos relacionados às afecções das vias respiratórias. Tal fenômeno figura como variável de confusão neste estudo, uma vez que as queimadas na região sudeste ocorrem justamente no mesmo período.

Ocorre que, é possível estabelecer um padrão de incidência para o Estado de São Paulo, e ainda observar incidência acima do padrão em locais onde ocorreu queimada. É importante salientar que fatores como condições climáticas e padrão sócio-econômico do local de estudo, devem ser considerados em pesquisas que envolvem comparação entre localidades.

A utilização de tecnologias de geoprocessamento possibilita identificar relacionamentos entre distribuição de agravos à saúde e condicionantes ambientais, agregando e mapeando variáveis de fontes distintas.

Para tanto, este trabalho foi estruturado na perspectiva de obter resultados em duas abordagens escalares. Primeiramente construiuse um SIG com abrangência regional, considerando os 645 municípios do Estado de São Paulo. O resultado desta fase indicou regiões candidatas à observação de incidência acima do padrão, em função das queimadas, que carecem de estudos mais aprofundados sobre os fenômenos abordados.

A segunda fase consistiu da construção de um SIG em escala mais detalhada, abrangendo a meso-região administrativa de Bauru, possibilitando estudar exposição e efeito em populações no entorno de áreas canavieiras. 
Após a construção do SIG, iniciou-se uma análise dos dados georreferenciados ${ }^{5}$ que resultou nas cartas temáticas elaboradas neste estudo.

Entende-se que este trabalho possui uma abordagem interdisciplinar, visto que o campo de Saúde Pública, no qual se encaixa o objeto desta pesquisa, não é passível de ser englobado ou reduzido a uma única disciplina (BRUYNE, 1882 citado por ALVARENGA, 1994). Para tanto, dada a complexidade do problema, este estudo foi encaminhado agregando conhecimentos nas áreas:

- Saúde Pública - Geografia da Saúde;

- Meteorologia - Difusão Atmosférica;

- Informática - Geoprocessamento.

Para estudar o processo saúde-doença de um agravo, é necessário conhecer o lugar de ocorrência. Os mapas são modelos computacionais da realidade que são, portanto, representações de um lugar onde é possível organizar dados e estabelecer correlações em uma análise.

Neste enfoque, as escalas permitem um olhar diferenciado na análise e determinação dos fenômenos em função do nível de detalhe apresentado. As simplificações assumidas são aquelas que não fazem parte da abstração do estudo porque, não são todas as características do lugar que interessam a uma determinada pesquisa. Portanto, a escala escolhida determina o detalhe que se deseja observar.

\footnotetext{
${ }^{5}$ Georreferenciamento é o processo de referenciar dados a um sistema de coordenadas terrestre ou a uma unidade territorial (bairro, município, etc), utilizando um geocódigo. Geocódigo é um identificador comum entre dados gráficos e não gráficos que permite relacioná-los. (MS 2000, p. 111)
} 
Por este motivo, a implementação deste estudo demandou resultados apresentados em 2 escalas, a primeira com enfoque regional, abrangendo o Estado de São Paulo por inteiro e, a segunda, em escala local, focando a meso-região de Bauru e suas peculiaridades dentro do escopo do estudo.

\subsubsection{Enfoque Regional}

O estudo partiu da aquisição de dados secundários que formaram o conjunto de elementos para a construção do SIG na escala 1:250.000. Esta abordagem permitiu gerar cartas temáticas agregando dados sobre incidência de internação por afecções das vias respiratórias no Estado de São Paulo no período de janeiro de 2000 a dezembro de 2004, considerando o polígono municipal como a menor unidade geográfica. Para compor os mapas temáticos, utilizou-se também um mosaico de imagens de satélite que dá ênfase às áreas de plantio de cana-de-açúcar gerada pelo Instituto Agronômico do Estado de São Paulo e os dados sobre focos de calor captados por satélite, disponibilizados pelo INPE. A camada de polígonos municipais foi utilizada como mapa base para a sobreposição das demais camadas necessárias nesta dimensão analítica.

Neste enfoque, a pesquisa caracterizou-se por ser um estudo ecológico, pois os mapas temáticos aqui gerados, agregaram dados secundários gerados por instituições públicas, agregados em um período de 5 anos para avaliar a evolução dos fenômenos observados no âmbito do Estado de São Paulo. 
Em suma, construiu-se:

- 5 mapas temáticos (1 para cada ano abordado no estudo) utilizando-se as camadas municípios (polígono), meso-regiões (polígono), áreas de plantio (raster) e focos de queimada (ponto), afim de observar áreas coincidentes e padrões sazonais.

- 5 mapas temáticos (1 para cada ano abordado no estudo) utilizando-se as camadas municípios (polígono), incidência de internações por afecções (cores para os polígonos municipais) e focos de queimada (ponto), afim de observar áreas coincidentes e padrões sazonais.

- 1 mapa temático para o ano de 2004 contendo os mesmo dados dos mapas anteriores, porém acrescido de uma camada gerada por interpolação, utilizando o algoritmo IDW (Inverse Distance Weighting), afim de discutir diferenças entre duas técnicas de distribuição de dados em mapas.

- 4 mapas com as mesmas camadas dos mapas anteriores, porém com dados agrupados por trimestre para o ano de 2004, afim de observar a evolução das variáveis "queimada" e "internação por afecção" e a sazonalidade das ocorrências no período de um ano.

Ao final desta etapa, foi possível identificar nas cartas temáticas, áreas de interesse para estudos em escala local através de técnicas de análise espacial. 


\subsubsection{Enfoque Local}

Os mapas temáticos construídos na fase anterior, possibilitaram observar a distribuição dos agravos ambientais e dos problemas de saúde. Em particular, a meso-região administrativa de Bauru despertou interesse devido ao fato de possuir uma grande concentração de áreas de plantio, que gera conseqüentemente, intensa atividade de queimadas concentradas na mesma área. Em contraste, os demais municípios da mesma meso-região, não apresentam as mesmas características pois desenvolvem outros tipos de atividade econômica.

Esta dicotomia envolvendo os 56 municípios da meso-região permitiu analisar a evolução das internações por afecções respiratórias considerando duas regiões distintas em relação à condicionante ambiental "queimada".

Para cada foco de queimada, utilizou-se uma técnica de geoprocessamento denominada Buffer que consiste em criar uma camada no SIG com circunferências geradas a partir de pontos distribuídos no mapa. No caso, cada ponto de queimada, foi o centro de uma circunferência com raio de $10 \mathrm{Km}$, distância esta, estimada como área de influência que a pluma de compostos gerada por uma queimada poderia alcançar.

Obviamente, fatores como clima, velocidade e sentido do vento, temperatura do ar, umidade relativa e relevo da região, tem influência direta no comportamento da dispersão dos poluentes na atmosfera (CASTRO, GOUVEIA e ESCAMILLA-CEJUDO, 2003). Ou seja, Para estimar com maior precisão a área de influência de um composto, é necessário construir o modelo matemático da pluma utilizando as variáveis ambientais. $\mathrm{Na}$ escala adotada para este trabalho, optou-se 
por uma estimativa através da geração de buffers criados a partir da coordenada geográfica do foco de calor. Isso permitiu identificar intersecções entre a área de influência da queimada e os municípios que apresentaram incidência de internações por afecções.

A título de potencializar as possibilidades das ferramentas utilizadas, anexou-se uma rosa-dos-ventos do município de Bauru afim de se explorar uma leitura considerando a predominância da direção de dispersão das plumas de compostos gerados pelas queimadas nesta área.

A análise deste enfoque foi conduzida sob a ótica da identificação e comparação de dados de saúde entre municípios localizados no entorno de áreas de queimada e os dados de saúde de municípios similares, localizados a distância de áreas de queimada, no mesmo período da simulação.

\subsection{Aquisição de dados:}

Todos os dados não gráficos utilizados neste estudo são secundários, gerados por instituições públicas e disponibilizados gratuitamente pela internet, a exceção da carta digital da malha municipal do Estado de São Paulo que é comercializada pelo IBGE (Instituto Brasileiro de Geografia e Estatística) (IBGE, 2004). O mosaico de cobertura vegetal indicando áreas de plantio de cana-deaçúcar, foi obtido junto ao Centro de Tecnologia Copersucar em Piracicaba (COPERSUCAR, 2005).

Os dados sobre focos de calor no Estado de São Paulo são indícios de queimada e estão disponíveis na internet em formato de 
planilha eletrônica e foto de satélite, com informações a partir de 01 de junho de 1998 (INPE, 2003).

\subsubsection{Malha municipal do Estado de São Paulo}

Utilizou-se a carta digitalizada da malha municipal, na escala 1:250.000, projeção Latitude / Longitude, Datum ${ }^{6}$ SAD 69, obtida junto ao IBGE - Instituto Brasileiro de Geografia e Estatística (IBGE, 2004). Tal carta georreferenciada, acompanha uma base de dados com os atributos descritos no Quadro 2:

\begin{tabular}{|l|l|}
\hline Atributo & Descrição \\
\hline Nome_município & Nome do município representado pelo polígono associado. \\
\hline População_1996 & População do município estimada em 1996 \\
\hline Nome_UF & Nome da Unidade da Federação a qual o município pertence \\
\hline Sigla_UF & Sigla da Unidade da Federação a qual o município pertence \\
\hline Cód_UF & Código IBGE da Unidade da Federação a qual o município pertence \\
\hline Área & Área de abrangência do município \\
\hline Perímetro & Perímetro do Município \\
\hline Cód_municipio & Código IBGE do Município \\
\hline Cód_região & Região brasileira onde o município está localizado \\
\hline Cód_meso & Código da meso região estadual onde o município está localizado \\
\hline Nome_meso & Nome da meso região estadual onde o município está localizado \\
\hline Cód_micro & Código da micro região estadual onde o município está localizado \\
\hline Nome_micro & Nome da micro região estadual onde o município está localizado \\
\hline Longitude & Longitude do centróide do polígono municipal \\
\hline Latitude & Latitude do centróide do polígono municipal \\
\hline Pop_total & População do município levantada no CENSO 2000. \\
\hline Total_homem & População de homens no município levantada no CENSO 2000 \\
\hline Total_mulher & População de mulheres no município levantada no CENSO 2000 \\
\hline Pop_urbana & População urbana do município levantada no CENSO 2000 \\
\hline Pop_rural & População rural do município levantada no CENSO 2000 \\
\hline Homem_urbana & População urbana de homens no município levantada no CENSO 2000 \\
\hline Mulher_urbana & População urbana de mulheres no município levantada no CENSO 2000 \\
\hline Homem_rural & População rural de homens no município levantada no CENSO 2000 \\
\hline Mulher_rural & População rural de mulheres no município levantada no CENSO 2000 \\
\hline
\end{tabular}

Quadro 2: Dicionarização da tabela associada à carta digitalizada da malha municipal do IBGE. Fonte (IBGE, 2004)

\footnotetext{
${ }^{6}$ DATUM - Um conjunto de parâmetros e pontos de controle usados para definir com precisão a forma da Terra. O datum é a base dos sistemas de coordenadas. Fonte: CARVALHO, PINA e SANTOS, 2000.
} 
A esta tabela, acrescentou-se o campo regional de saúde para permitir agrupar municípios segundo este critério.

\subsubsection{Internações por afecções ${ }^{7}$}

Os dados foram obtidos do sistema de informações hospitalares do SUS - SIH/SUS. São dados provenientes de hospitais da rede pública ou particular conveniados do SUS, que enviam informações das internações efetuadas por AlH (Autorização de Internação Hospitalar) para os gestores municipais e estaduais. As AlH são processadas pelo DATASUS e seus dados são disponibilizados para consulta pública na Internet (DATASUS, 2004).

O sistema de consultas inicialmente apresenta a possibilidade de selecionar procedimentos computados por município de residência do paciente ou por município de internação. Para esta pesquisa, optou-se pelos dados computados por município de residência, partindo-se do princípio de que o paciente permanece mais tempo em seu município de residência, aumentando assim a suscetibilidade à exposição, caso seja este, um município de que sofre a ação das queimadas. Segundo porque a opção de seleção por município de internação, representa um viés de confusão, uma vez que não foi lá que o paciente ficou exposto.

Uma vez definido qual o método de contagem, o sistema disponibiliza uma tela de parametrização da consulta onde o usuário deve definir quais variáveis quer visualizar e quais filtros serão utilizados.

\footnotetext{
${ }^{7}$ Afecção: "Processo mórbido considerado em suas manifestações atuais, com abstração de sua causa primordial; doença”. Fonte: AURÉLIO, 1988.
} 
Os seguintes critérios foram selecionados:

- Linha: Município;

- Coluna: Mês competência;

- Conteúdo: internações;

- Período disponível: ano inteiro (selecionar todos os meses do ano);

- Grupo de procedimento: Afecções das vias aéreas superiores;

- Formato: Colunas separadas por ponto e vírgula (;).

No caso deste estudo, utilizou-se o grupo de procedimentos "Afecções das vias aéreas superiores" por este agregar os procedimentos referentes às doenças descritas no Capítulo 10 Doenças do Aparelho Respiratório, da CID-10.

O Quadro 3 apresenta a lista das afecções descritas no capítulo 10 da CID-10, contempladas na seleção.

\begin{tabular}{|l|}
\hline CID-10, Capítulo 10: Doenças do aparelho respiratório (J00-J99) \\
\hline J00-J06 Infecções agudas das vias aéreas superiores \\
\hline J00 Nasofaringite aguda [resfriado comum] \\
\hline J01 Sinusite aguda \\
\hline J02 Faringite aguda \\
\hline J03 Amigdalite aguda \\
\hline J04 Laringite e traqueíte agudas \\
\hline J05 Laringite obstrutiva aguda [crupe] e epiglotite \\
\hline J06 Infecções agudas das vias aéreas superiores de localizações múltiplas e não \\
especificadas \\
\hline J30-J39 Outras doenças das vias aéreas superiores \\
\hline J31 Rinite, nasofaringite e faringite crônicas \\
\hline J32 Sinusite crônica \\
\hline J33 Pólipo nasal \\
\hline J34 Outros transtornos do nariz e dos seios paranasais \\
\hline J35 Doenças crônicas das amígdalas e das adenóides \\
\hline J36 Abscesso periamigdaliano \\
\hline J37 Laringite e laringotraqueíte crônicas \\
\hline J38 Doenças das cordas vocais e da laringe não classificadas em outra parte \\
\hline J39 Outras doenças das vias aéreas superiores \\
\hline J60 Pneumoconiose dos mineiros de carvão \\
\hline J61 Pneumoconiose devida a amianto [asbesto] e outras fibras minerais \\
\hline J62 Pneumoconiose devida a poeira que contenham sílica \\
\hline J63 Pneumoconiose devida a outras poeiras inorgânicas \\
\hline
\end{tabular}




\begin{tabular}{|l|}
\hline Capítulo 10: Doenças do aparelho respiratório (J00-J99) (Continuação...) \\
\hline J64 Pneumoconiose não especificada \\
\hline J65 Pneumoconiose associada com tuberculose \\
\hline J66 Doenças das vias aéreas devida a poeiras orgânicas específicas \\
\hline J67 Pneumonite de hipersensibilidade devida a poeiras orgânicas \\
\hline $\begin{array}{l}\text { J68 Afecções respiratórias devidas a inalação de produtos químicos, gases, fumaças e } \\
\text { vapores }\end{array}$ \\
\hline J69 Pneumonite devida a sólidos e líquidos \\
\hline J70 Afecções respiratórias devida a outros agentes externos \\
\hline J80-J84 Outras doenças respiratórias que afetam principalmente o interstício \\
\hline J80 Síndrome do desconforto respiratório do adulto \\
\hline J81 Edema pulmonar, não especificado de outra forma \\
\hline J82 Eosinofilia pulmonar, não classificada em outra parte \\
\hline J84 Outras doenças pulmonares intersticiais \\
\hline J95-J99 Outras doenças do aparelho respiratório \\
\hline J95 Afecções respiratórias pós-procedimentos não classificadas em outra parte \\
\hline J96 Insuficiência respiratória não classificada de outra parte \\
\hline J98 Outros transtornos respiratórios \\
\hline J99 Transtornos respiratórios em doenças classificadas em outra parte \\
\hline
\end{tabular}

Quadro 3: Doenças do aparelho respiratório associadas às vias aéreas superiores. Fonte: WHO, 1993.

Como resultado da seleção, o sistema gerou um arquivo em formato texto com os atributos apresentados no Quadro 4.

\begin{tabular}{|l|l|}
\hline Atributo & Descrição \\
\hline Município & Código IBGE e nome do município. \\
\hline Jan, Fev,...Dez & $\begin{array}{l}\text { Total de internações por afecção registradas no município (uma coluna } \\
\text { para cada mês) }\end{array}$ \\
\hline Total & Total de internações por afecção registradas no município no ano. \\
\hline
\end{tabular}

Quadro 4: Dicionarização da tabela obtida na consulta aos procedimentos hospitalares do SIH. Fonte: DATASUS, 2004.

O procedimento de consulta foi repetido 5 vezes para obter uma tabela resultado para cada ano necessário ao estudo (de 2000 a 2004).

Os arquivos foram importados para o formato MS-Access 2000. Entre os gerenciadores de banco de dados disponíveis, este 
apresentou facilidades no manuseio dos dados para posterior agregação à ferramenta SIG. Para isso, utilizou-se o assistente de importação disponível no MS-Access 2000. Após a importação, executou-se uma operação na tabela para separar os valores dos códigos IBGE do município e do nome do município, que estavam condicionados no mesmo atributo e criariam problemas futuros na associação com as outras camadas do SIG.

As 5 tabelas criadas no MS-Access 2000 foram agregadas a uma única, adicionada do atributo "ANO" para diferenciar o período das ocorrências. Uma vez concluída a criação da tabela de afecções, esta foi incorporada ao SIG, associada à malha municipal através do atributo código IBGE do município, comum às duas bases de dados.

\subsubsection{Focos de calor captados por satélite}

A DPI (Divisão de Processamento de Imagens) do INPE (Instituto Nacional de Pesquisas Espaciais) participa de um programa de monitoramento de queimadas através da captação de focos de calor por satélite. Como parte deste programa, criou-se um banco de dados geográfico disponível pela internet contendo dados georreferenciados sobre queimadas, imagens de satélite, localização de áreas de desmatamento e áreas de conservação entre outros, possibilitando criar camadas para compor mapas temáticos nos SIG's (INPE, 2005).

O banco de dados armazena e disponibiliza informações captadas nos países: Brasil, Bolívia, Paraguai, Peru e Venezuela por intermédio de 4 satélites a saber: 
1) NOAA 12: Passagem dos horários: $9: 00$ horas e 21:00 horas $\left(\mathrm{GMT}^{8}\right)$.

2) NOAA 16: Passagem dos horários: 5:00 horas e 16 horas (GMT).

3) GOES 8/12: Passagem dos horários: 0:00, 3:00, 6:00, 9:00, 12:00, 15:00, 18:00 e 21:00 horas (GMT).

4) MODIS 01: Passagem dos horários: 01:00, 05:00, 14:00 e 17:00 horas (GMT).

Para este estudo, foram extraídos do banco de dados de queimadas as informações sobre focos de calor no período de janeiro de 2000 até dezembro de 2004, captados pelo satélite NOAA 12 no período noturno. Justifica-se a filtragem da base pelos seguintes motivos:

- Devido às restrições impostas pela legislação ambiental, as queimadas de cana-de-açúcar devem ocorrer no período noturno.

- O satélite NOAA 12 faz a varredura do território brasileiro no horário das 21 horas GMT (equivalente a 18 horas em São Paulo).

- O satélite NOAA 12 possui dados registrados a partir de 01 de junho de 1998, os demais possuem registros a partir de 2003, não contemplando as necessidades deste estudo.

- A eventual utilização de dados provenientes de 2 satélites poderia acarretar em duplicidade do dado, uma vez que não há como identificar redundâncias no banco de dados.

O Quadro 5 apresenta a estrutura de dados sobre os focos de calor que o INPE disponibiliza.

\footnotetext{
${ }^{8}$ GMT - Greenwich Mean Time. Horário medido no Royal Observatory, na cidade de Greenwish, Inglaterra. Fonte: Greenwich Mean Time, 2005.
} 


\begin{tabular}{|l|l|l|}
\hline Campo & Tipo de dado & Descrição \\
\hline $\mathrm{Nr}$ & Número & Seqüencial para identificação do foco. \\
\hline Lat & Número & Latitude da ocorrência do foco em decimais. \\
\hline Long & Número & Longitude da ocorrência do foco em decimais. \\
\hline LatGMS & Texto & $\begin{array}{l}\text { Latitude de localização do foco em coordenada } \\
\text { GMS }\end{array}$ \\
\hline LongGMS & Texto & $\begin{array}{l}\text { Longitude de localização do foco em coordenada } \\
\text { GMS. }\end{array}$ \\
\hline Data & Texto & Data da ocorrência. \\
\hline Hora & Texto & Hora da ocorrência. \\
\hline Satélite & Texto & Satélite que captou. \\
\hline Município & Texto & Município da ocorrência. \\
\hline Estado & Texto & Unidade da federação da ocorrência. \\
\hline Pais & Texto & País da ocorrência. \\
\hline Vegetação & Texto & Vegetação predominante no local da ocorrência \\
\hline Sucetibilidade & Texto & Grau de suscetibilidade da região ao uso do fogo \\
\hline Precipitação & Número & $\begin{array}{l}\text { Quantidade de chuva (em milímetros) acumuladas } \\
\text { nos últimos 15 dias na região }\end{array}$ \\
\hline NumDiasSemChuva & Número & Número de dias sem chuva no local \\
\hline Risco & Número & $\begin{array}{l}\text { Potencialidade de ocorrência de focos na região, } \\
\text { varia de Mínimo (indica ocorrência de foco em } \\
\text { áreas onde as condições meteorológicas não são } \\
\text { favoráveis a ocorrência deste foco) até Crítico } \\
\text { (áreas que, segundo as condições meteorológicas, } \\
\text { são propícias a ocorrerem focos) }\end{array}$ \\
\hline Persistência & Número & $\begin{array}{l}\text { Quantidade de horas em que foi verificado outros } \\
\text { focos num raio de 1.5 km do foco em questão }\end{array}$ \\
\hline
\end{tabular}

Quadro 5 - Dicionarização da tabela de focos de calor detectados por satélite, disponibilizada pelo INPE - Monitoramento de Queimadas. Fonte: INPE, 2005.

O sistema disponível no site do DPI gera um arquivo texto com os campos delimitados por vírgula, após definir os critérios de seleção de dados. Dado o volume do material necessário para este estudo (da ordem de 3000 ocorrências / ano) e a limitação da ferramenta de busca, fez-se necessário fragmentar a extração de dados por semestre, gerando então 10 arquivos de dados nesta etapa.

Em seguida, os arquivos obtidos, foram importados para o MSAccess 2000 da Microsoft e agrupados em 5 tabelas (uma para cada

\footnotetext{
${ }^{9}$ GMS - Coordenadas em grau, minuto e segundo.
} 
ano) utilizando-se o mesmo mecanismo de importação de dados descrito anteriormente, ocorrido com os dados das afecções.

Concluída a criação das tabelas, deu-se seqüência à incorporação das tabelas no SIG. Este procedimento teve duas etapas. A primeira, a simples inserção das tabelas no sistema, que ocorre com a abertura da tabela na ferramenta. A segunda etapa, consistiu na criação de uma camada com os pontos referentes aos focos de calor. Este procedimento foi executado no MAPINFO através da opção do menu "Tables", "Create Points". Selecionando esta opção, uma janela solicita a indicação da tabela de referência, os campos com valores para Latitude e Longitude, e a definição do sistema de projeção e respectivo datum. (neste caso, optou-se por projeção de latitude e longitude, utilizando-se o datum SAD 69, para compatibilizar com o mapa da malha municipal).

Para obter a camada de áreas sob influência das queimadas, utilizou-se uma ferramenta do MAPINFO para gerar buffers a partir de pontos georreferenciados no mapa. Para atender o objetivo de criar mapas temáticos por trimestre, fez-se necessário em primeiro lugar, selecionar e gerar camadas de focos de calor por trimestre do ano de 2004.

A ferramenta "SQL Select" disponível no MAPINFO permitiu selecionar pontos de um trimestre para criar cada uma das 4 camadas trimestrais. Isso feito, os pontos de um trimestre foram selecionados para, em seguida gerar um buffer com a ferramenta "Buffer Objects" como mostra a Figura 5. 


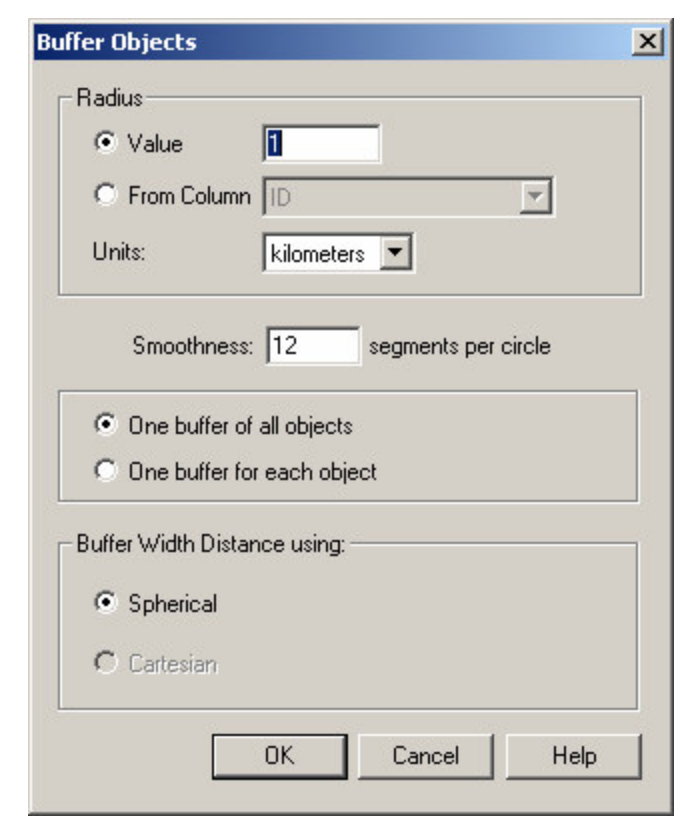

Figura 5 - Janela "Buffer Objects" do MAPINFO.

A opção Radius foi preenchida com o valor igual a 10 e unidade igual a Kilometers para a ferramenta gerar buffers de $10 \mathrm{Km}$ de raio. Optou-se por gerar 1 único buffer para todos os objetos porque o intuito foi gerar um polígono que cobrisse as áreas impactadas.

4.2.4. Áreas de Plantio de cana-de-açúcar no Estado de São Paulo.

O Centro de Tecnologia Copersucar, em Piracicaba, disponibilizou o mosaico de imagens obtidas por satélite, apresentando informações sobre a cobertura vegetal do Estado de São Paulo. Algumas regiões foram desconsideradas por não representar relevância para este tipo de atividade agrícola e, portanto, não estão contempladas no mosaico. Em específico, as áreas de plantio de cana-de-açúcar foram ressaltadas com a cor amarela. Esta 
imagem raster $^{10}$, disponibilizada em formato $\mathrm{JPEG}^{11}$, foi georreferenciada no MAPINFO através da ferramenta "Image Registration". Tal ferramenta permite especificar um conjunto de coordenadas latitudinais e longitudinais para um grupo de pontos da imagem, de forma que a figura seja ajustada ao padrão de coordenadas especificado. A Figura 6 apresenta a janela do MAPINFO utilizada para executar este procedimento.

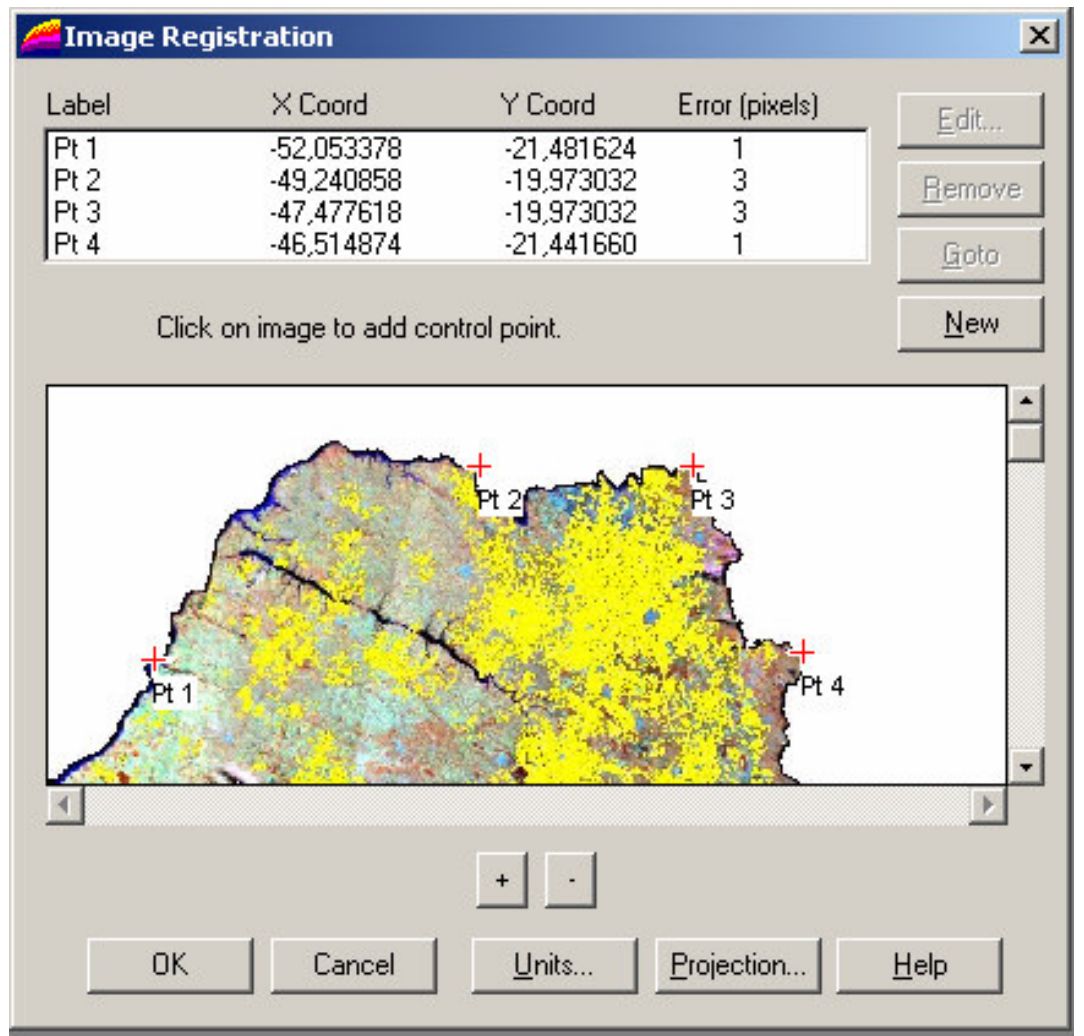

Figura 6: Janela "Image Registration" do MAPINFO.

\footnotetext{
${ }^{10}$ Raster: Estrutura de dados matricial, composta de linhas e colunas para armazenamento de imagens. Fonte: CARVALHO, PINA e SANTOS, 2000.

${ }^{11}$ JPEG: Formato padronizado para compactação de imagens. Fonte: JPEG ORG, 2005.
} 


\subsection{Estruturação do SIG}

Foram estruturados dois bancos de dados geográficos na execução deste trabalho em função dos resultados esperados nas escalas propostas. Em ambos os casos, houve necessidade de modelar o banco de dados orientado ao tema do estudo, considerando - armazenamento dos dados não gráficos, dados gráficos, identificadores para relacionamento entre tais elementos agregados a um repositório com características de data warehouse ${ }^{12}$.

Bancos de dados podem ser modelados para duas finalidades genéricas. Estas finalidades são conhecidas pelas siglas OLAP (Online Analytical Processing) e OLTP (Online Transaction Processing). Os bancos de dados OLAP são modelados com o intuito de oferecer acesso rápido aos dados a fim de promover análise dos mesmos, ou seja, são estruturados para facilitar a recuperação dos dados armazenados. Já os bancos de dados OLTP, são modelados com a finalidade de agilizar o processo de armazenamento dos dados, buscando qualidade na consistência dos conteúdos armazenados (KIMBALL, 1998).

Dada a diversidade de fontes de dados, estes estão disponíveis em formatos variados. O trabalho de adequação dos dados para um único formato, a ser estabelecido no data warehouse, requer uma atenção especial pois demanda tarefas que envolvem conhecimento de programas específicos, domínio de técnicas de manipulação de dados e conhecimentos de linguagem de programação em alguns

\footnotetext{
${ }^{12}$ Um data warehouse é um repositório de informações coletadas em diversas fontes, armazenadas sob um esquema único, em um só local (SILBERSCHATZ et. al 1999, p. 713)
} 
casos. Em especial, o domínio da linguagem SQL ${ }^{13}$ (Structure Query Language) se faz necessário neste tema, bem como no momento posterior de extração de dados.

\subsection{Processamento de Dados}

Sistemas de geoprocessamento necessitam de um arcabouço tecnológico envolvendo equipamentos de informática, periféricos e programas específicos. Tal conjunto deve contar com insumos capazes de atender o marco conceitual sistêmico de um SIG, ou seja: Entrada de dados, Armazenamento, Processamento e Saída (OPAS, 2002).

Há uma variedade de programas e equipamentos que podem colaborar nas diversas demandas de um SIG como armazenamento de dados, migração de formato de dados, manipulação de imagens, geocodificação, análise espacial, entre outras.

Todos os elementos que necessitam de tratamento computacional neste estudo, foram executados sob o Sistema Operacional Microsoft Windows 2000 que facilitou a integração entre formatos de arquivos de dados e programas.

Para o desenvolvimento deste estudo, utilizaram-se os seguintes recursos computacionais:

- Computador Pessoal, contendo processador AMD Athlon, com 384 Mbytes de memória RAM, unidade de disco flexível de 3 1⁄2

\footnotetext{
${ }^{13}$ Dentre as linguagens formais o SQL é uma linguagem padrão para consultas em bancos de dados relacionais (SILBERSCHATZ et. al 1999, p. 109).
} 
polegadas, unidade de CD-RW (leitura e gravação), monitor de vídeo padrão SVGA 17 polegadas, teclado e mouse.

- Sistema Operacional Microsoft Windows versão 2000.

- Programa de manipulação de imagens Microsoft Paint versão 5.0 (disponível com o Microsoft Windows versão 2000).

- Sistema Gerenciador de Banco de Dados Microsoft Access versão 2000.

- Planilha Eletrônica Microsoft Excel versão 2000.

- Ferramenta de SIG MAPINFO Professional versão 6.5 (inglês).

Todas as imagens geradas, foram obtidas pelo software MAPINFO e posteriormente trabalhadas no utilitário Microsoft Paint para, finalmente serem incluídas neste trabalho.

O gráfico foi construído na planilha eletrônica Microsoft Excel 2000, com os dados exportados do software Microsoft Access 2000.

Todos os dados provenientes de bases de dados foram convertidos para o Microsoft Access 2000, de onde foi possível gerar os resultados estatísticos deste estudo.

As seleções de dados, bem como os agrupamentos de camadas (no MAPINFO é chamado Workspace) foram gravados em disco para eventuais reprocessamentos.

Utilizou-se 100 Mbytes de espaço em disco rígido para armazenar todos os arquivos criados neste estudo. 


\section{RESULTADOS E ANÁLISE}

\subsection{Resultados do Enfoque Regional}

O Estado de São Paulo, possui 15 meso-regiões administrativas onde, algumas meso-regiões como Ribeirão Preto, Araraquara e Piracicaba possuem quase a totalidade de suas extensões preenchidas pela monocultura canavieira. O Mapa 11 apresenta as manchas de cobertura da cultura de cana-de-açúcar no Estado de São Paulo e as respectivas delimitações das meso-regiões administrativas estaduais.

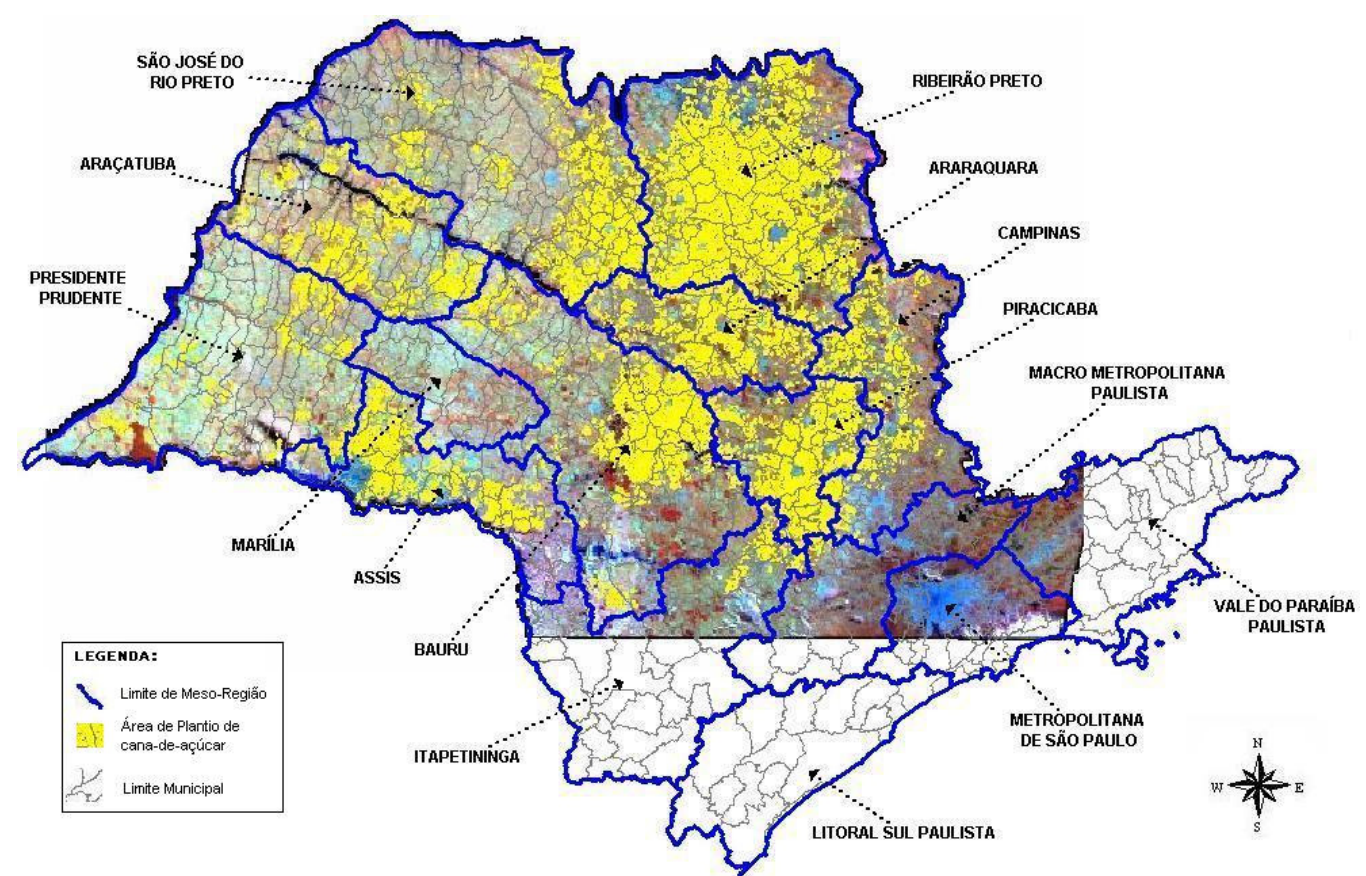

Mapa 11 - Distribuição das áreas de plantio de cana-de-açúcar no Estado de São Paulo nas meso-regiões administrativas estaduais. Fontes: COPERSUCAR, 2005; IBGE, 2004;

Organizado pelo autor. 
Outras meso-regiões como Araçatuba, Assis, Bauru, Presidente Prudente e São José do Rio Preto, encontram-se situadas no entorno dos pólos da produção canavieira paulista e dividem boa parte de sua extensão territorial entre a cultura da cana-de-açúcar e outras culturas. Ainda sim, algumas meso-regiões como Itapetininga, Litoral Sul Paulista, Marília, Metropolitana de São Paulo, Macro Metropolitana Paulista e Vale do Paraíba, pouco ou nada investem na cultura da gramínea.

Através da sobreposição de uma camada de focos de calor ao Mapa 11, é possível observar a coincidência das concentrações de tais focos sobre as áreas de plantio de cana-de-açúcar, comprovando que a utilização da técnica de queimada ainda é largamente utilizada em toda a extensão do Estado.

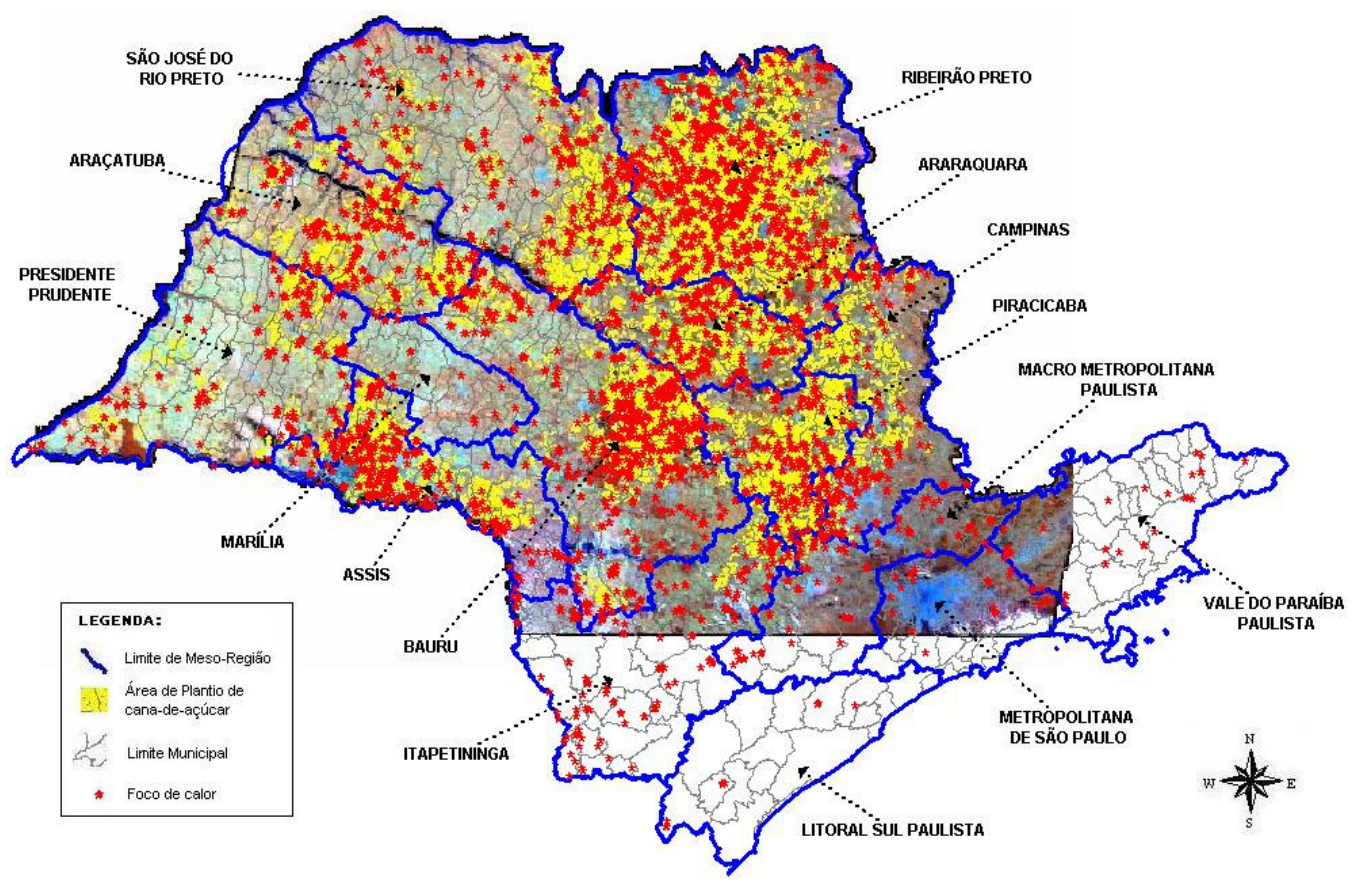

Mapa 12 - Focos de calor no Estado de São Paulo no ano de 2000, distribuídos nas mesoregiões administrativas estaduais. Fontes: COPERSUCAR, 2005; IBGE, 2004; INPE, 2005; Organizado pelo autor. 
O mesmo padrão de coincidência repete-se para os anos seguintes, conforme apresenta os Mapas 13, 14, 15 e 16, respectivamente para os anos 2001, 2002, 2003 e 2004.

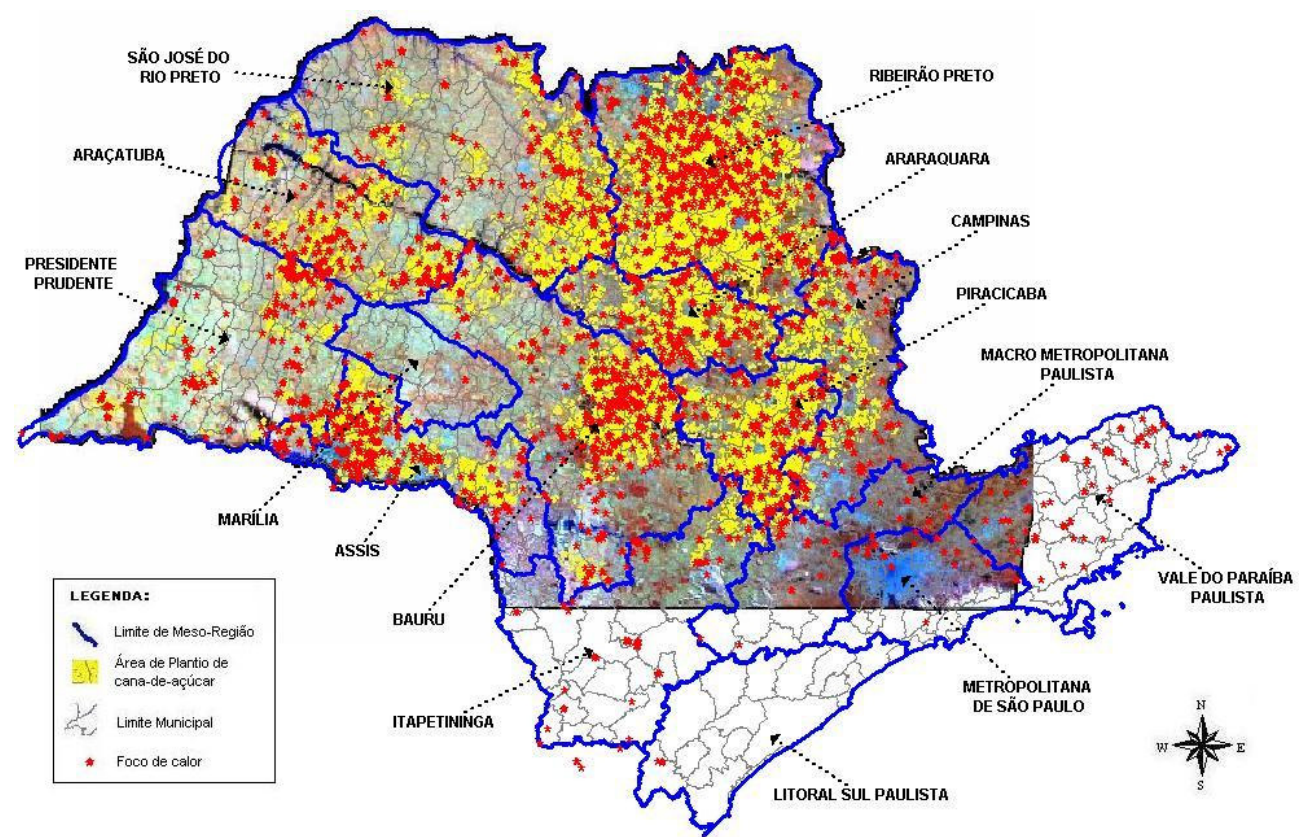

Mapa 13: Focos de calor no Estado de São Paulo no ano de 2001, distribuídos nas mesoregiões administrativas estaduais. Fontes: COPERSUCAR, 2005; IBGE, 2004; INPE, 2005; Organizado pelo autor.

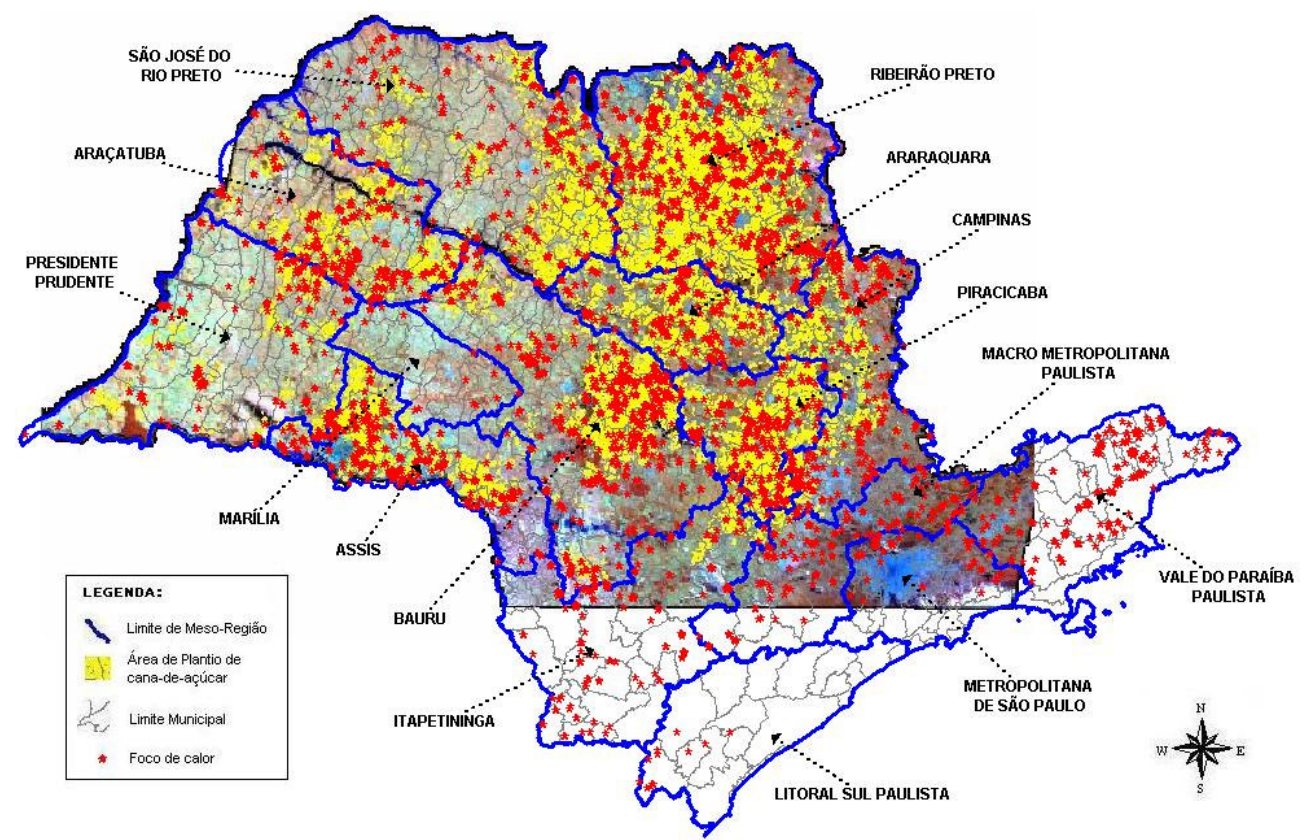

Mapa 14 - Focos de calor no Estado de São Paulo no ano de 2002, distribuídos nas mesoregiões administrativas estaduais. Fontes: COPERSUCAR, 2005; IBGE, 2004; INPE, 2005; Organizado pelo autor. 


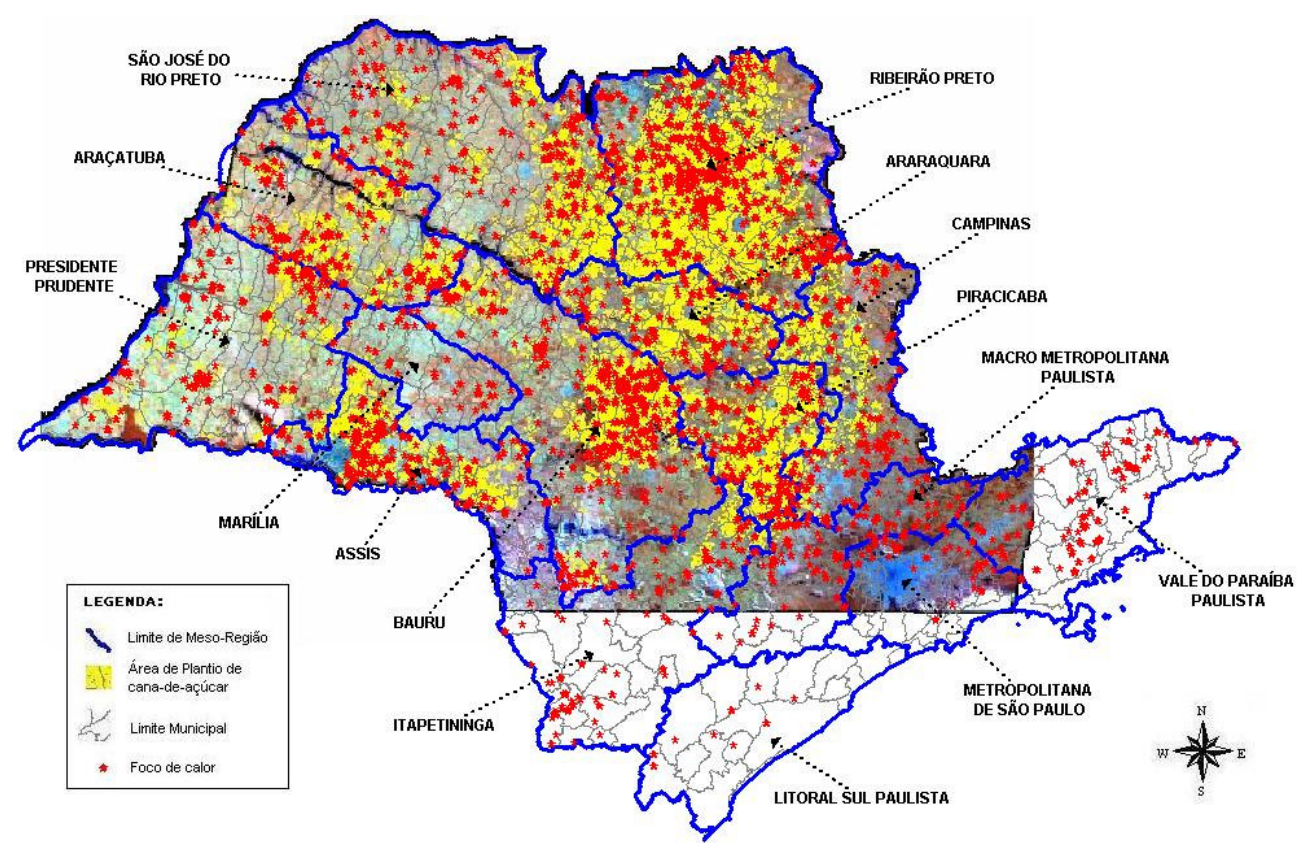

Mapa 15 - Focos de calor no Estado de São Paulo no ano de 2003, distribuídos nas mesoregiões administrativas estaduais. Fontes: COPERSUCAR, 2005; IBGE, 2004; INPE, 2005; Organizado pelo autor.

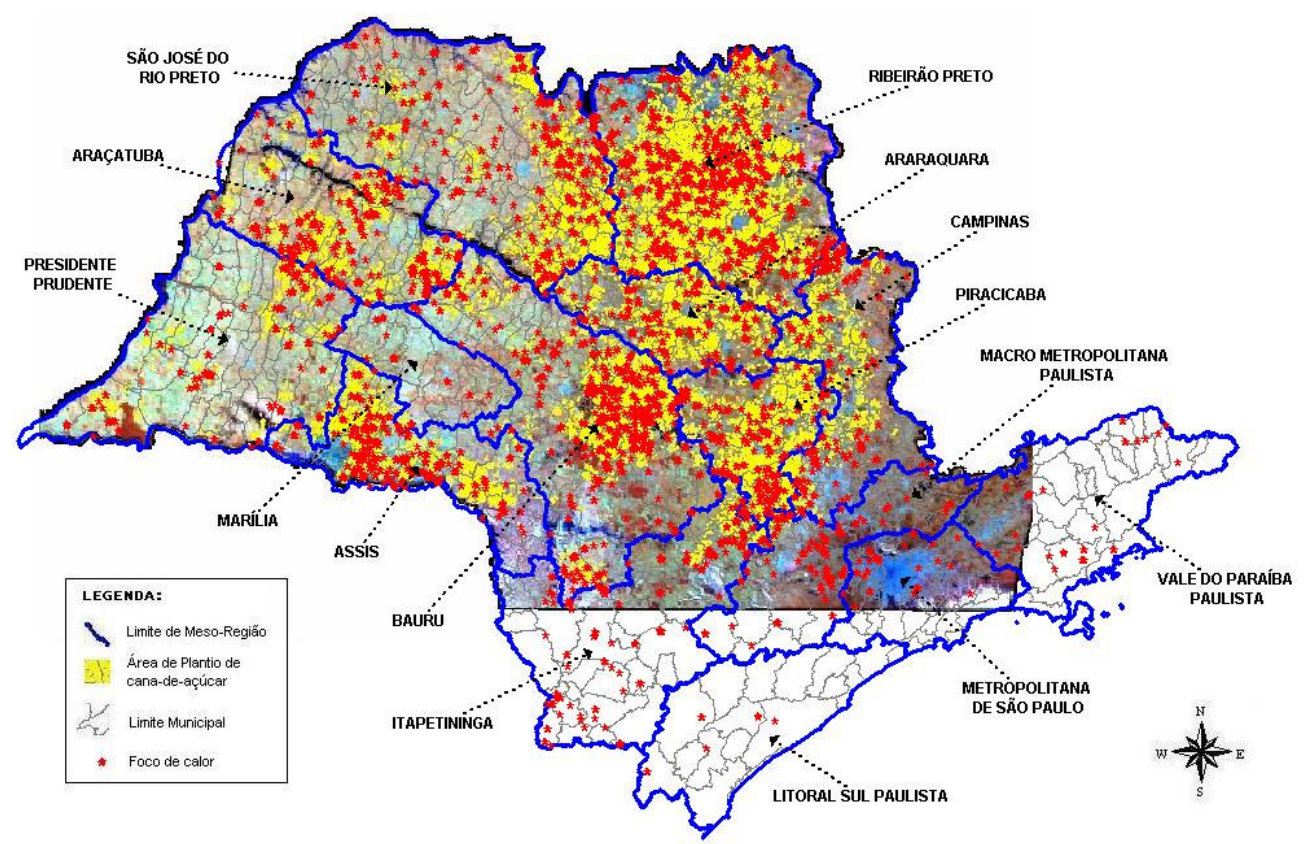

Mapa 16 - Focos de calor no Estado de São Paulo no ano de 2004, distribuídos nas mesoregiões administrativas estaduais. Fontes: COPERSUCAR, 2005; IBGE, 2004; INPE, 2005; Organizado pelo autor. 
Neste mesmo contexto, utilizando a técnica de sobreposição de camadas, é possível observar que os municípios possuidores dos mais altos coeficientes de incidência de internações por afecções das vias respiratórias, encontram-se nas mesmas áreas onde ocorrem as maiores concentrações de queimadas. Os mapas 17, 18, 19, 20 e 21, apresentam a distribuição de incidência das internações por afecções acumuladas no ano para cada 10.000 habitantes. Nesta série é possível observar que o fenômeno manteve o padrão nos últimos 5 anos.

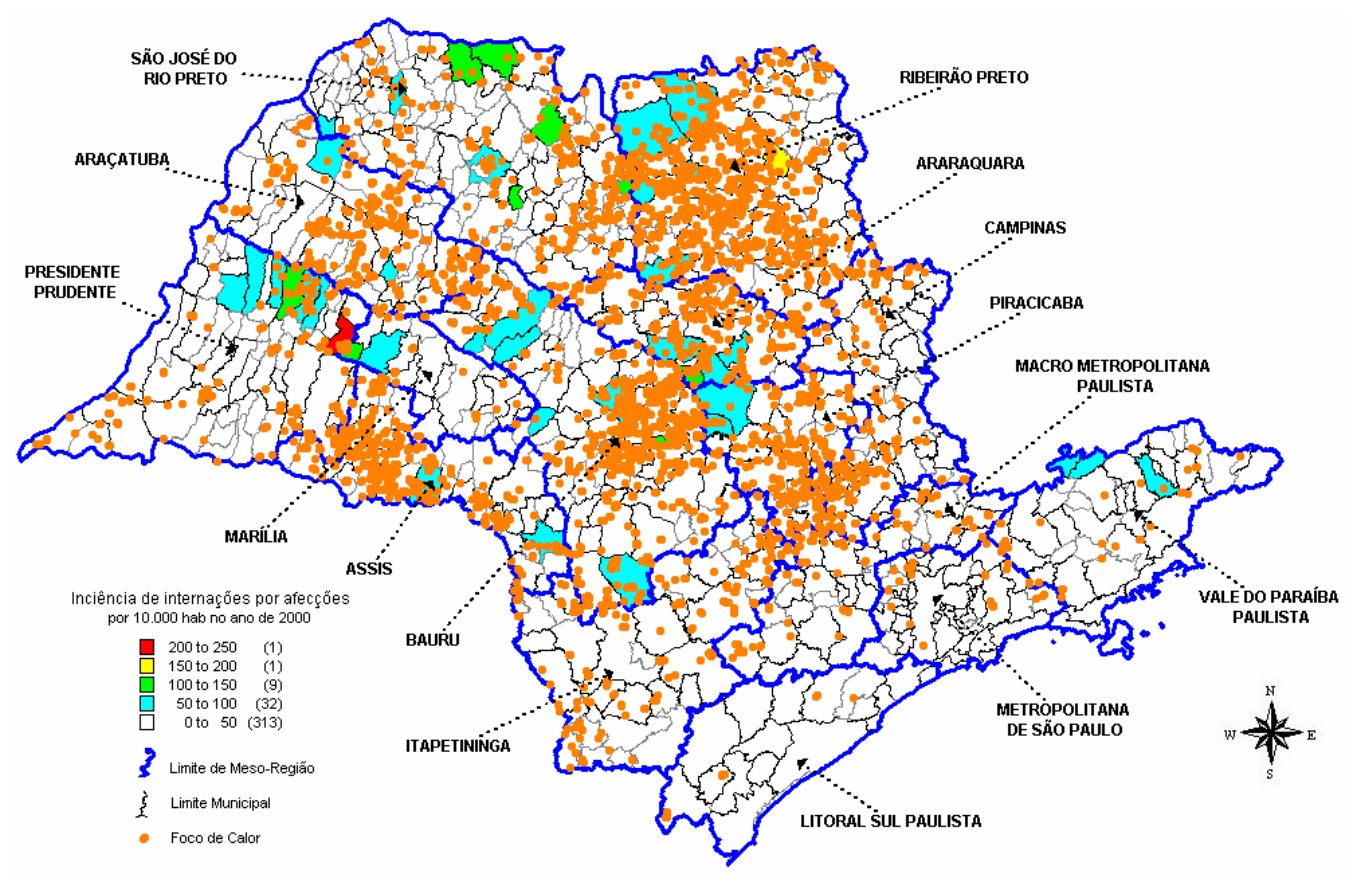

Mapa 17 - Distribuição da Incidência de internações por afecções nas vias respiratórias e focos de calor no Estado de São Paulo no ano de 2000, nas meso-regiões administrativas estaduais. Fontes: DATASUS, 2004; IBGE, 2004; INPE, 2005; Organizado pelo autor. 


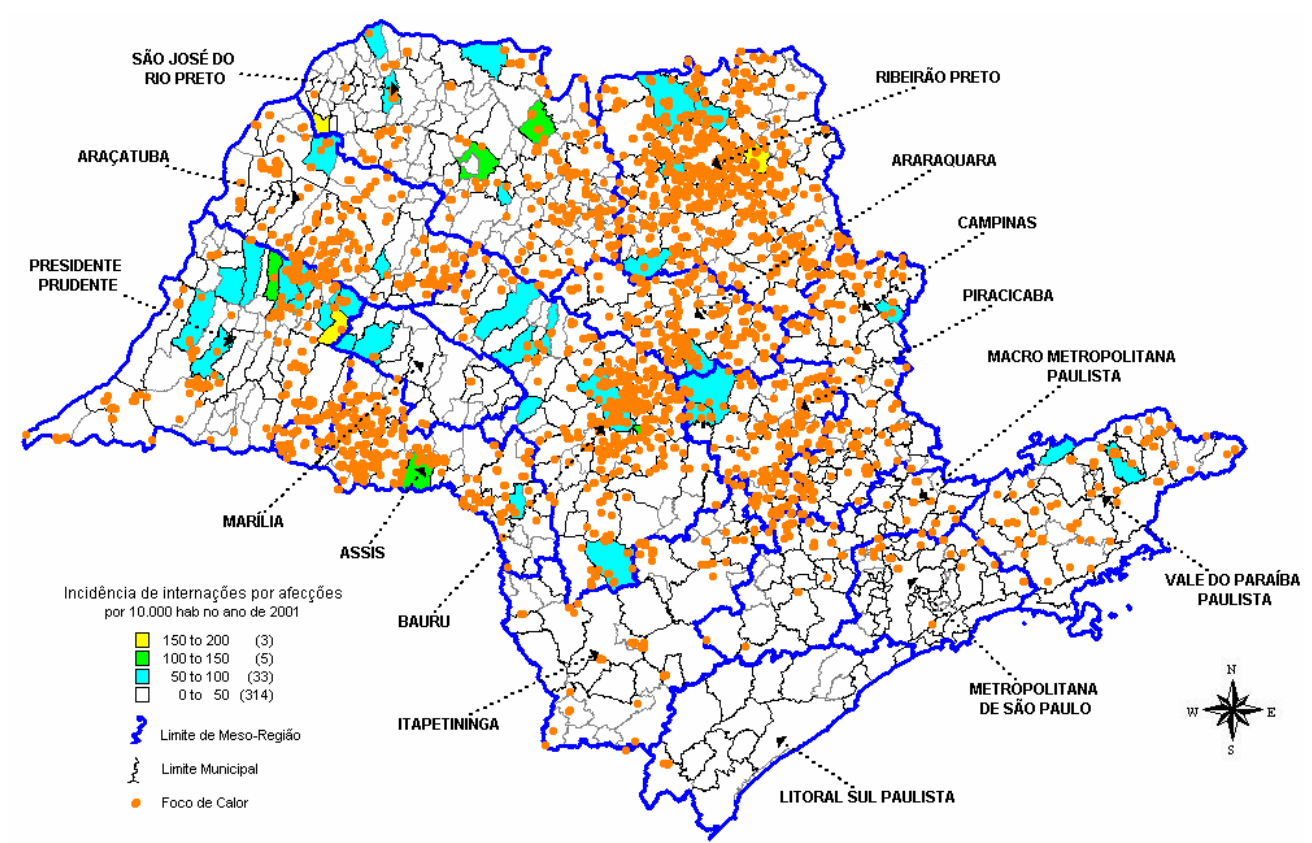

Mapa 18 - Distribuição da Incidência de internações por afecções nas vias respiratórias e focos de calor no Estado de São Paulo no ano de 2001, nas meso-regiões administrativas estaduais. Fontes: DATASUS, 2004; IBGE, 2004; INPE, 2005; Organizado pelo autor.

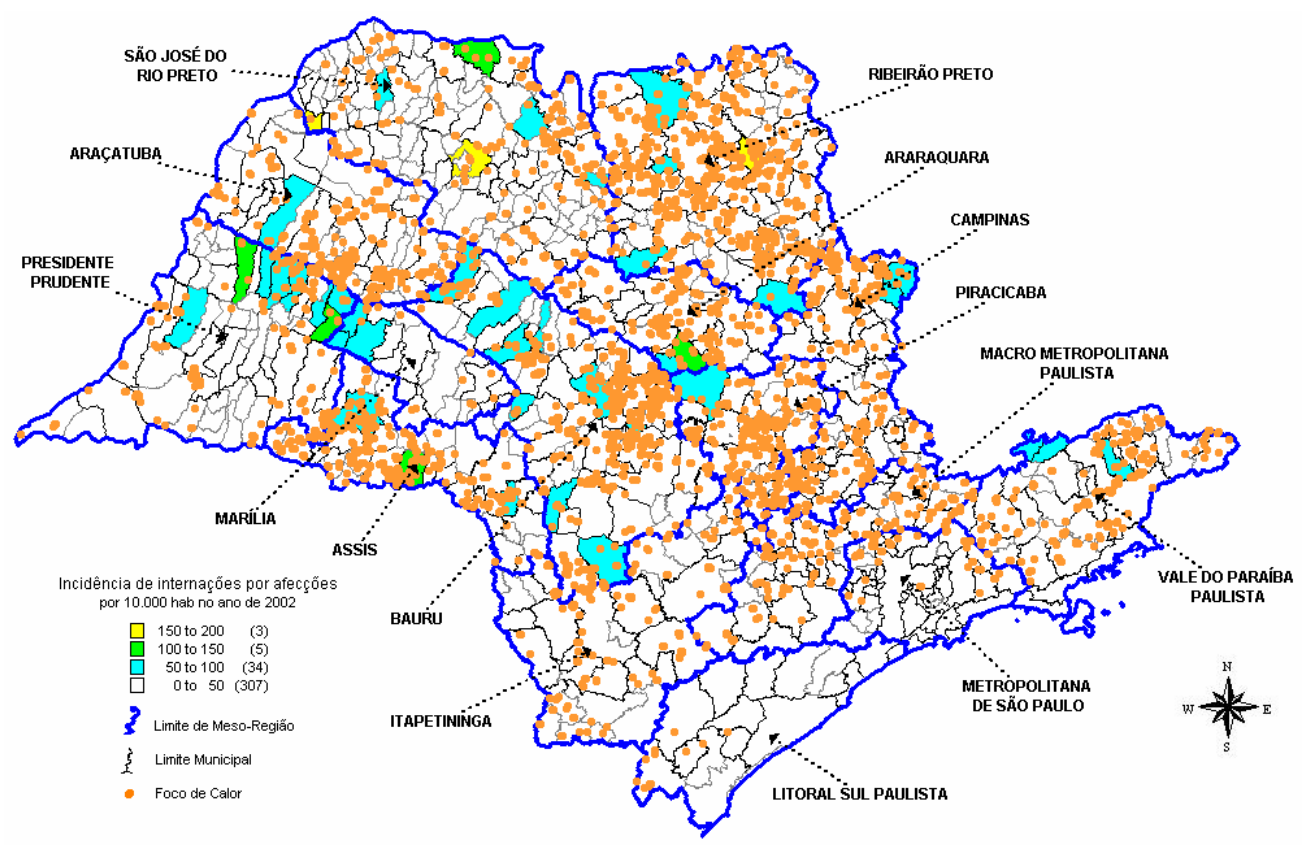

Mapa 19 - Distribuição da Incidência de internações por afecções nas vias respiratórias e focos de calor no Estado de São Paulo no ano de 2002, nas meso-regiões administrativas estaduais. Fontes: DATASUS, 2004; IBGE, 2004; INPE, 2005; Organizado pelo autor. 


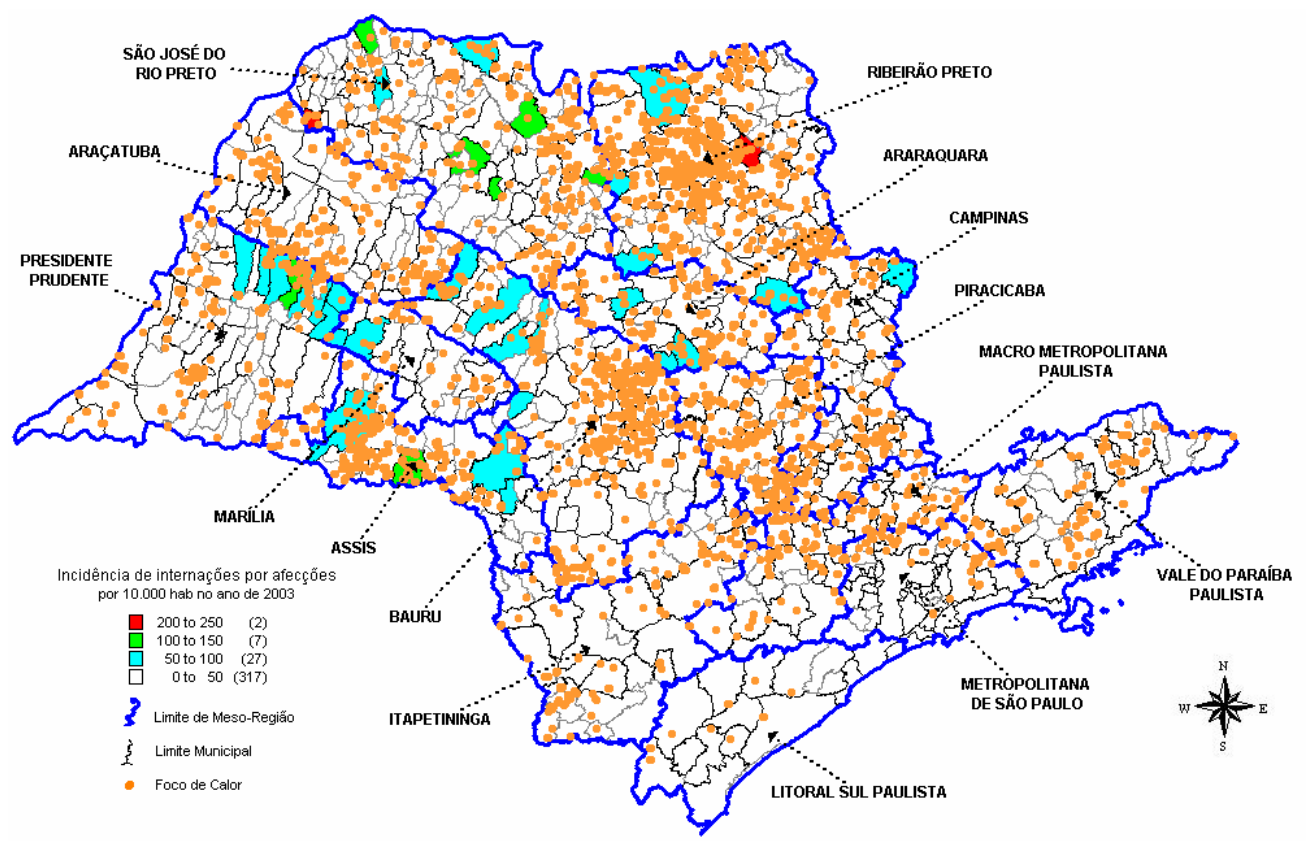

Mapa 20 - Distribuição da Incidência de internações por afecções nas vias respiratórias e focos de calor no Estado de São Paulo no ano de 2003, nas meso-regiões administrativas estaduais. Fontes: DATASUS, 2004; IBGE, 2004; INPE, 2005; Organizado pelo autor.

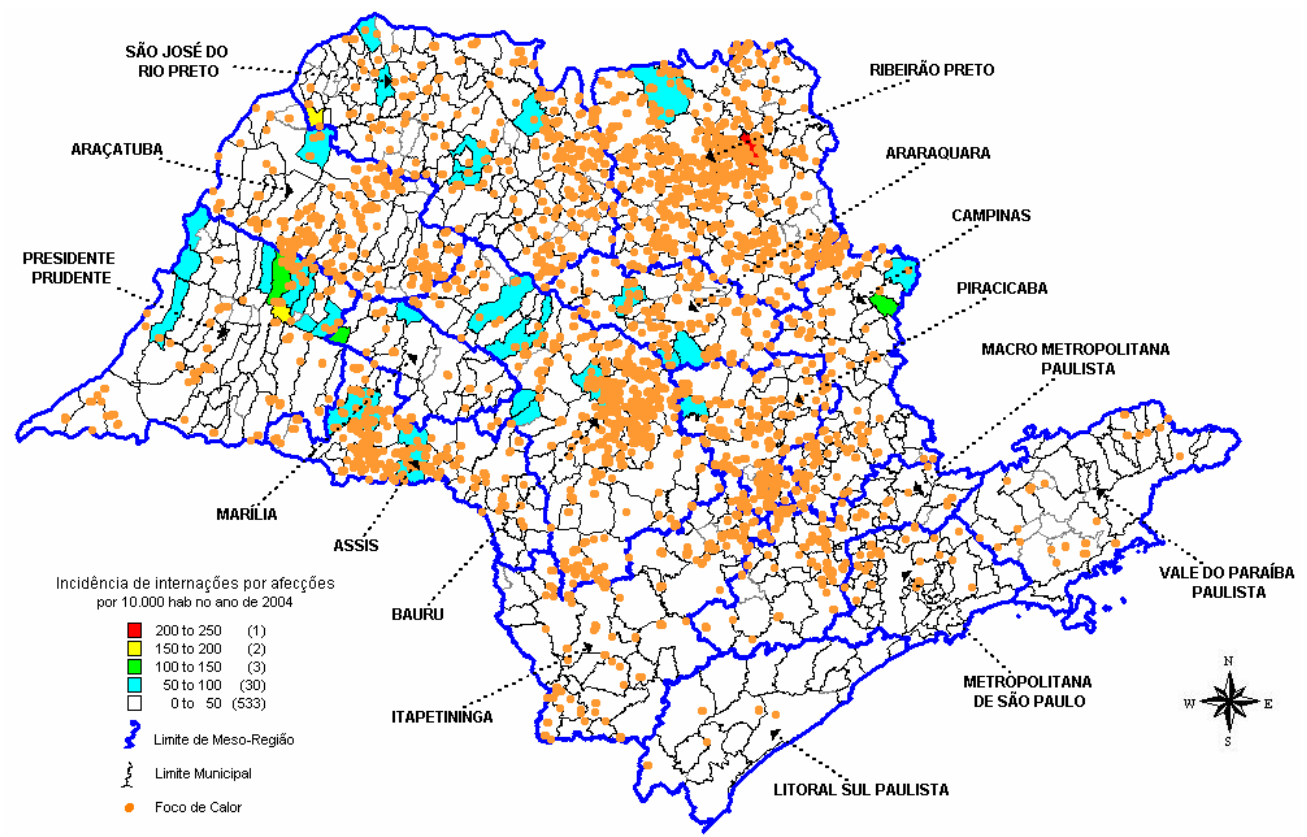

Mapa 21 - Distribuição da Incidência de internações por afecções nas vias respiratórias e focos de calor no Estado de São Paulo no ano de 2004, nas meso-regiões administrativas estaduais. Fontes: DATASUS, 2004; IBGE, 2004; INPE, 2005; Organizado pelo autor. 


\subsection{Análise do Enfoque Regional}

Os mapas temáticos foram compostos a partir da sobreposição das camadas focos de calor, casos de internação por afecção das vias respiratórias e áreas de plantio de cana-de-açúcar.

É importante salientar que foram consideradas as internações por afecções das vias respiratórias registradas no SIH/SUS (Sistema de Informações Hospitalares do SUS), que recebe dados de toda a rede pública, bem como da rede privada conveniada. Portanto, é provável haver sub-notificação de dados, uma vez que a rede privada não notifica a totalidade dos casos para o SIH/SUS. No entanto, a rede pública atende a grande maioria das internações no interior do Estado, coincidentemente nas áreas em que ocorrem as queimadas.

Ainda sim, há que se considerar alguns fatores que podem acarretar viés na leitura dos resultados, como é o caso dos municípios da meso-região Vale do Paraíba Paulista. Para os anos 2000, 2001 e 2002, os mapas apresentaram incidência entre 50 e 100 casos por 10.000 habitantes nos municípios de Campos do Jordão, Lorena e São Bento do Sapucaí. Esta região não possui cultura de cana-de-açúcar em escala significativa, porém está localizada na serra da Mantiqueira que, no período de seca (outono e primavera), apresenta ocorrência de queimadas em áreas de proteção ambiental como o Parque Nacional do Itatiaia entre outras regiões. Além disso, é comum a prática de queimada em áreas de pasto para nascer capim novo, mais apropriado para os bovinos.

Outro tipo de viés pode ocorrer na leitura dos dados para o município de Ribeirão Preto que apresentou incidência de internação por afecções elevada (entre 200 e 250 para cada 10.000 habitantes) no ano de 2004. Neste caso, a população ficou exposta os compostos 
provenientes das queimadas ocorridas em toda a região, somada ao produto da poluição veicular acentuada na área urbana deste município. Determinar quais fontes geraram as afecções, carece de estudos mais aprofundados nesta área.

Outra forma de trabalhar a camada das incidências é através do uso de interpolação dos dados por meio de algoritmos que trabalham distribuição de cores no mapa atribuindo peso para os polígonos. O Mapa 22 apresenta um resultado para esta técnica utilizando os dados de incidência em 2004.

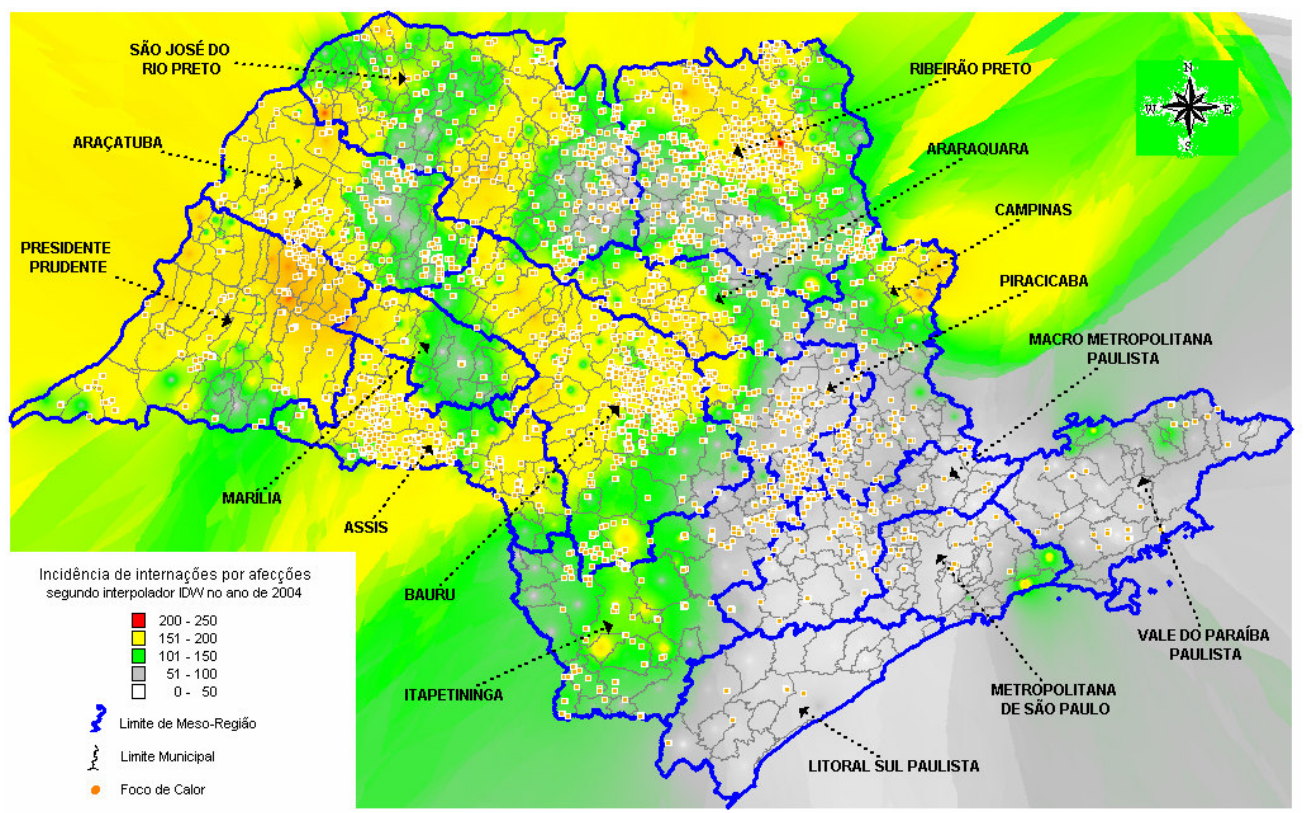

Mapa 22 - Grade de distribuição da incidência de internações por afecções nas vias respiratórias e focos de calor no Estado de São Paulo no ano de 2004, nas Meso-Regiões administrativas estaduais, gerada pelo interpolador IDW ${ }^{14}$. Fontes: DATASUS, 2004; IBGE, 2004; INPE, 2005; Organizado pelo autor.

Neste exemplo, a visualização do Mapa 22 ficou mais elegante que o correspondente Mapa 21, porém o modelo computacional gerou um resultado que potencializa o agravo, atribuindo valores de

\footnotetext{
${ }^{14}$ IDW (Inverse Distance Weighting): Algoritmo para gerar uma grade de valores a partir do peso médio da distância entre pontos de dados. Fonte: MAPINFO, 2001.
} 
incidência mais altos, dando a impressão de que o problema é muito maior que a realidade observada no Mapa 21.

Portanto, é importante avaliar os resultados obtidos nas técnicas de análise espacial disponíveis, para determinar qual será a mais adequada para a confecção de mapas temáticos de um estudo para evitar viés na leitura dos resultados da pesquisa.

Ainda sobre os dados do ano de 2004, foi possível construir um gráfico comparativo entre quantidade de focos de calor e incidência de internações conforme apresenta o Gráfico 2.

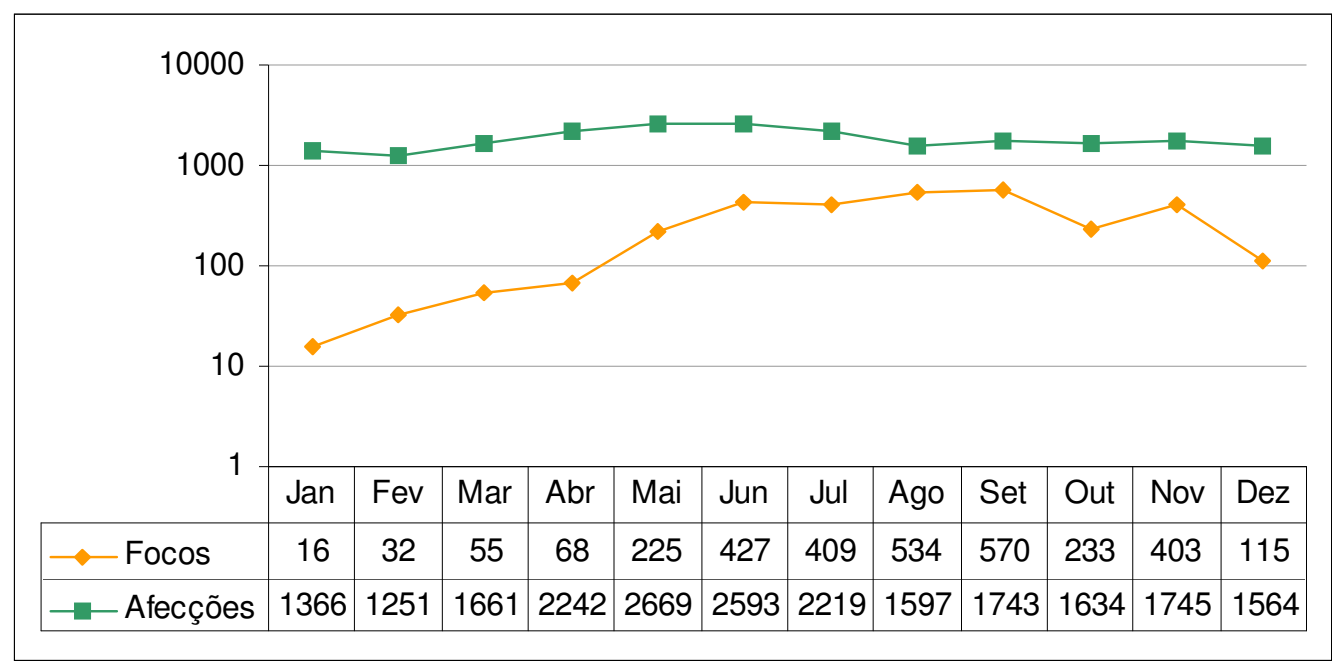

Gráfico 2: Evolução comparativa entre as ocorrências de internações por afecções das vias respiratórias e os focos de calor no Estado de São Paulo, no ano de 2004. Fontes: DATASUS, 2004; IBGE, 2004; Organizado pelo autor.

Nesta análise, o gráfico construído em escala logarítmica, não apresenta a similaridade esperada entre as curvas. Nota-se o crescimento do número de focos de calor no decorrer do ano, onde o período mais crítico abrange os meses de junho a setembro, coincidindo como o pico da colheita da cana-de-açúcar que vai até o mês de novembro. Porém, as afecções apresentam um pico mais 
retardado, coincidindo com o fim do outono e o período de inverno. Nos demais meses, mantêm-se estável.

Esta análise, ainda que preliminar, induz a raciocínio inverso à hipótese deste trabalho, ou seja, que os compostos produzidos na queima da palha da cana-de-açúcar, pouco ou nada influem no coeficiente de incidência de internação por afecções.

Obviamente, a construção de mais gráficos com dados fragmentados por região, ou município seria necessária para possibilitar visualizar algum fenômeno que indicasse uma tendência diferenciada. Isso demandaria tempo e dedicação do pesquisador, no sentido de tabular 3.087 focos de calor e 22.284 internações para 645 municípios em planilhas eletrônicas.

Ainda assim, existe uma dificuldade na leitura final devido ao fato de que os lugares, onde ocorrem os eventos, não são necessariamente delimitados pelas mesmas linhas divisórias estabelecidas pelo homem. Em outras palavras, os fenômenos ocorrem delimitados por outras formações poligonais que a própria natureza determina, e não a divisão política municipal ou mesoregional. Tal problema, é potencializado na identificação de fenômenos através da leitura de tabelas ou gráficos. Por este motivo, a distribuição dos dados em um mapa permite visualizar mais informações que as tabelas e gráficos.

A série de mapas $23,24,25$ e 26, apresenta os mesmos dados do ano de 2004, fragmentados por trimestre, com uma camada adicional gerada pela ferramenta Buffer. Esta construção considerou um raio de impacto de $10 \mathrm{Km}$ a partir do foco de calor, conforme esclarecido no anterior capítulo de metodologia deste trabalho. O intuito da série é visualizar a intersecção gerada entre o polígono interpolado por buffer e a incidência de internações. 


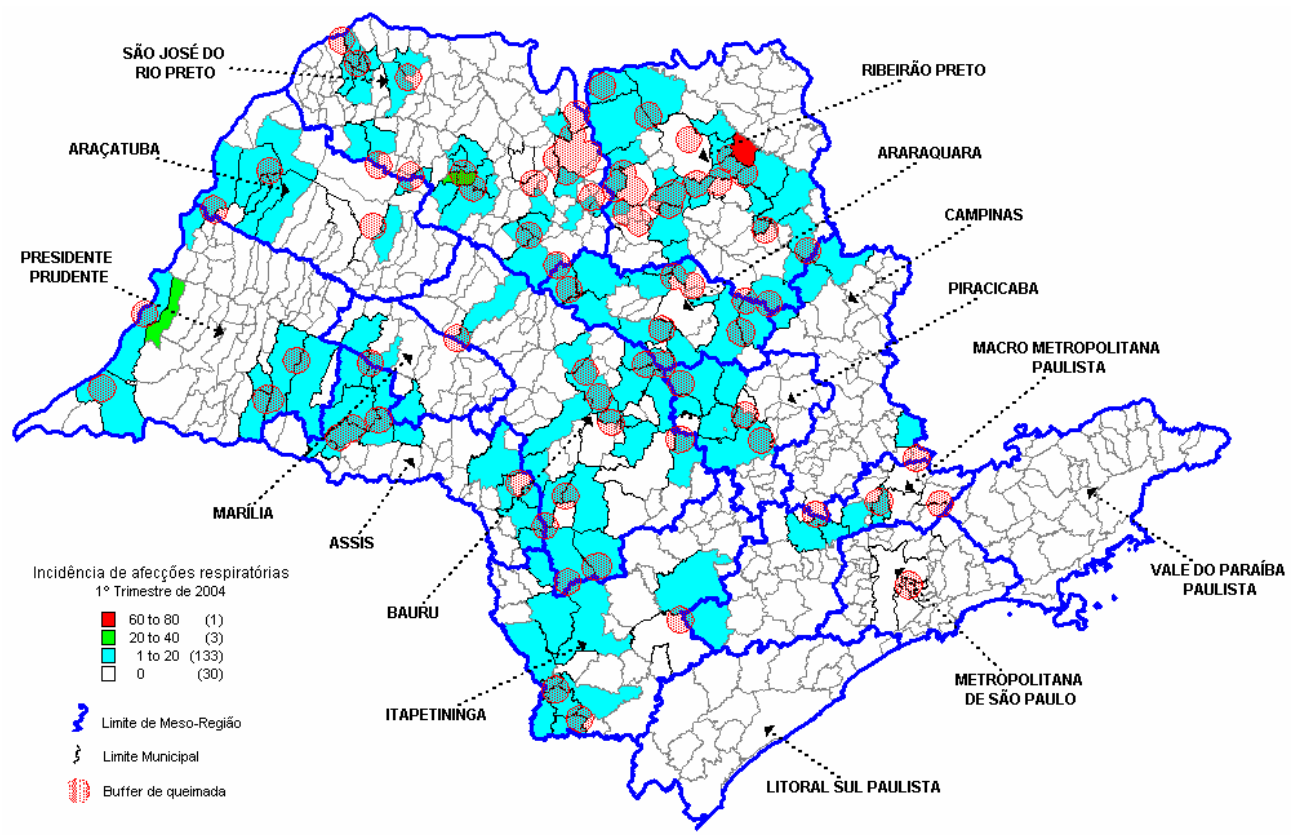

Mapa 23 - Distribuição da incidência de internações por afecções nas vias respiratórias e buffer dos focos de calor nas meso-regiões administrativas do Estado de São Paulo no primeiro trimestre do ano de 2004. Fontes: DATASUS, 2004; IBGE, 2004; INPE, 2005;

Organizado pelo autor.

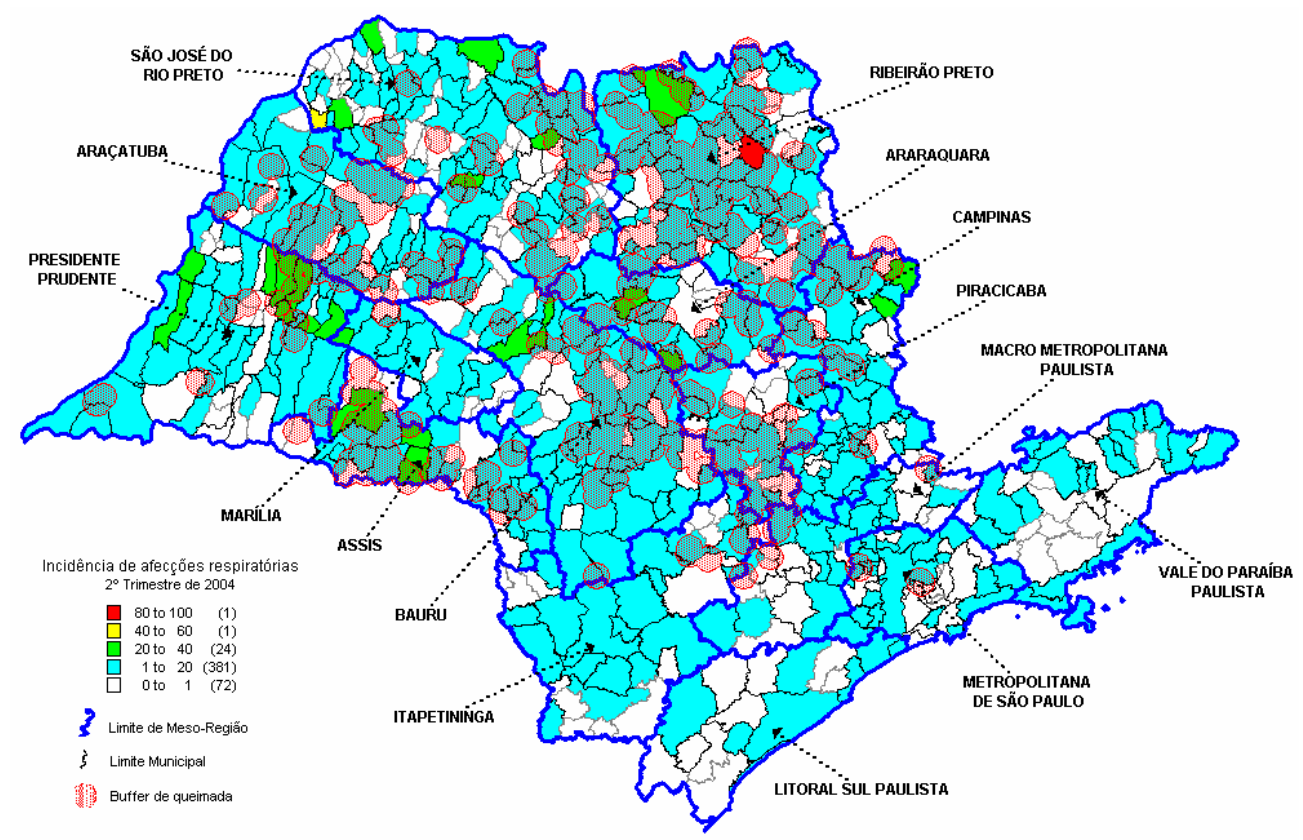

Mapa 24 - Distribuição da incidência de internações por afecções nas vias respiratórias e buffer dos focos de calor nas meso-regiões administrativas do Estado de São Paulo no segundo trimestre do ano de 2004. Fontes: DATASUS, 2004; IBGE, 2004; INPE, 2005; 


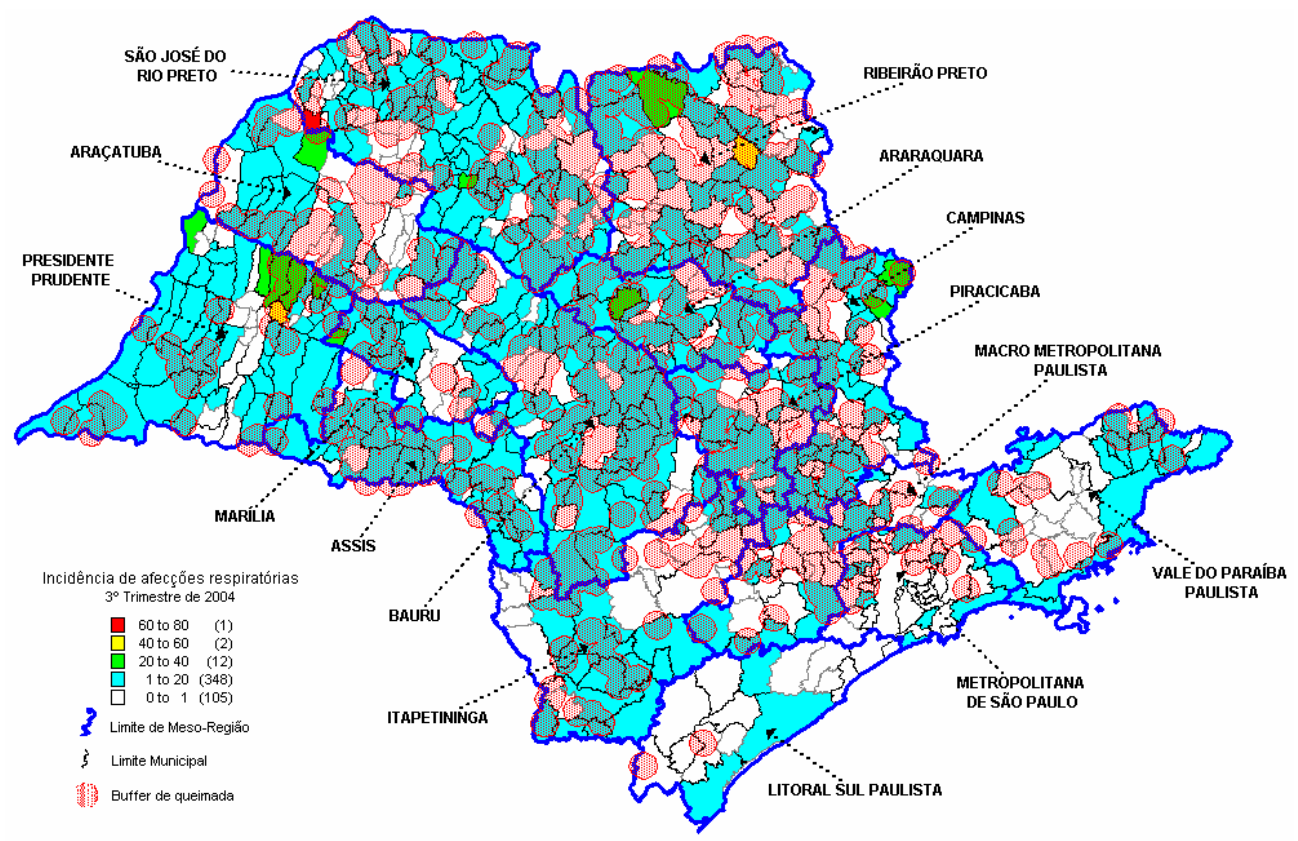

Mapa 25 - Distribuição da incidência de internações por afecções nas vias respiratórias e buffer dos focos de calor nas meso-regiões administrativas do Estado de São Paulo no terceiro trimestre do ano de 2004. Fontes: DATASUS, 2004; IBGE,2004; INPE, 2005;

Organizado pelo autor.

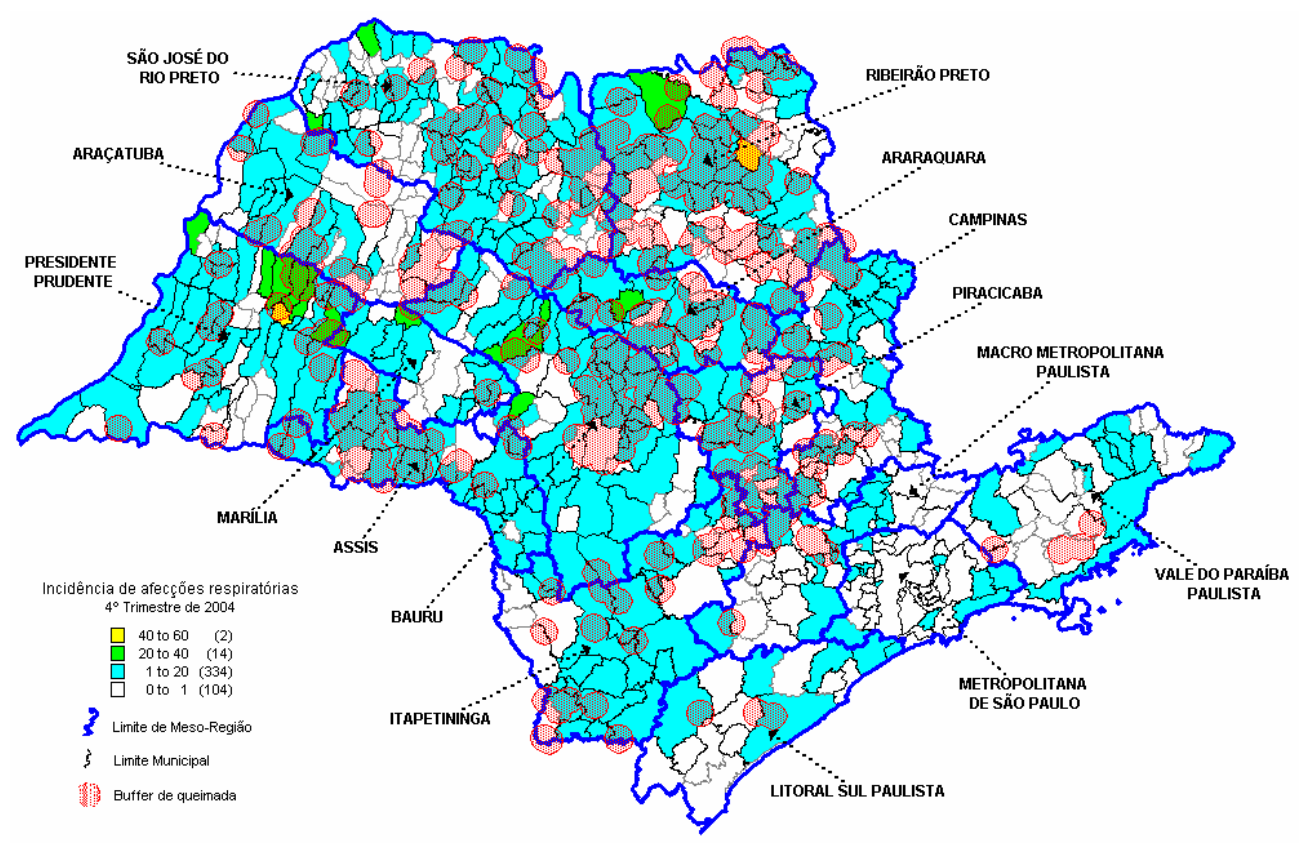

Mapa 26 - Distribuição da incidência de internações por afecções nas vias respiratórias e buffer dos focos de calor nas meso-regiões administrativas do Estado de São Paulo no quarto trimestre do ano de 2004. Fontes: DATASUS, 2004; IBGE,2004; INPE, 2005; Organizado pelo autor. 
O primeiro ponto a ressaltar sobre esta série de mapas, diz respeito à escala de cores utilizada na classificação das incidências. Esta foi alterada em função da fragmentação dos dados. A série anterior que agregou dados para o período de 1 ano apresentou alguns municípios com incidência superior a 200 internações para 10.000 habitantes. Neste caso, a fragmentação trimestral redefiniu grandezas para a quarta parte da média anual, obviamente.

O primeiro trimestre de 2004, devido ao fato de não pertencer ao período de colheita, e ser uma época de umidade mais elevada, apresenta uma visualização menos impactante na correlação queimada/incidência de internação. Porém, as ocorrências existem e a correlação visual também. A maioria dos municípios classificados por apresentar incidência maior que zero, contabilizam coeficientes baixos (entre 1 e 20 casos para 10.000 habitantes), a exceção do município de Nuporanga na meso-região de Ribeirão Preto, classificado na faixa de 80 a 100 casos para 10.000 habitantes. Nipoá e União Paulista (meso-região de Ribeirão Preto), Caiuá (meso-região de Presidente Prudente) foram classificados na faixa de 60 a 80 casos para 10.000 habitantes. Todos os casos coincidem com áreas impactadas por queimadas.

O segundo ponto a se colocar em epígrafe, refere-se à escala adotada. Devido ao conjunto de dados apresentado, a visualização do mapa temático ficou comprometida pois algumas áreas, como é o caso de Araraquara, Assis, Bauru, Piracicaba e Ribeirão Preto apresentam uma riqueza de detalhes que carece de visualização em maior escala.

Nesta linha, faz-se necessária a ampliação da escala, focada para áreas de interesse afim de se observar com maior clareza, os 
fenômenos pesquisados. Através da visualização trimestral, foi possível elencar várias áreas com ricas possibilidades de estudo. Meso-regiões como Araraquara, Piracicaba e Ribeirão Preto são mais complexas e demandariam estudos comparativos com outras áreas fora da abrangência da cultura canavieira.

Nesta abordagem, optou-se então pela escolha de uma mesoregião menos complexa, que apresentasse o condicionante ambiental predominante e, com influencia mínima de outras fontes poluidoras do ar. Com estas premissas, a meso-região de Bauru foi escolhida. Entre outros fatores, considerou-se o aspecto dicotômico observado para a variável ambiental, ou seja, esta região apresenta áreas com intensa atividade canavieira e outras sem sinais desta cultura.

\subsection{Resultados do Enfoque Local}

A ampliação da escala com foco para a meso-região de Bauru facilitou a visualização das variáveis distribuídas no mapa. As séries de mapas do enfoque regional foram elaboradas em escala onde $1 \mathrm{~cm}$ medido no mapa equivale a $37 \mathrm{Km}$, aglutinando assim grande sobreposição de dados no mesmo ponto do mapa. Neste enfoque, a escala foi ampliada e a visualização relação de escala passou a ser de $1 \mathrm{~cm}$ equivalente a $17 \mathrm{Km}$.

O Mapa 27 apresenta uma ampliação da região, contento pontos que indicam os respectivos centros urbanos municipais.

Mantendo-se a mesma classificação de cores anteriormente adotada, a série de mapas 28, 29, 30 e 31 apresentam a evolução trimestral nesta área. 


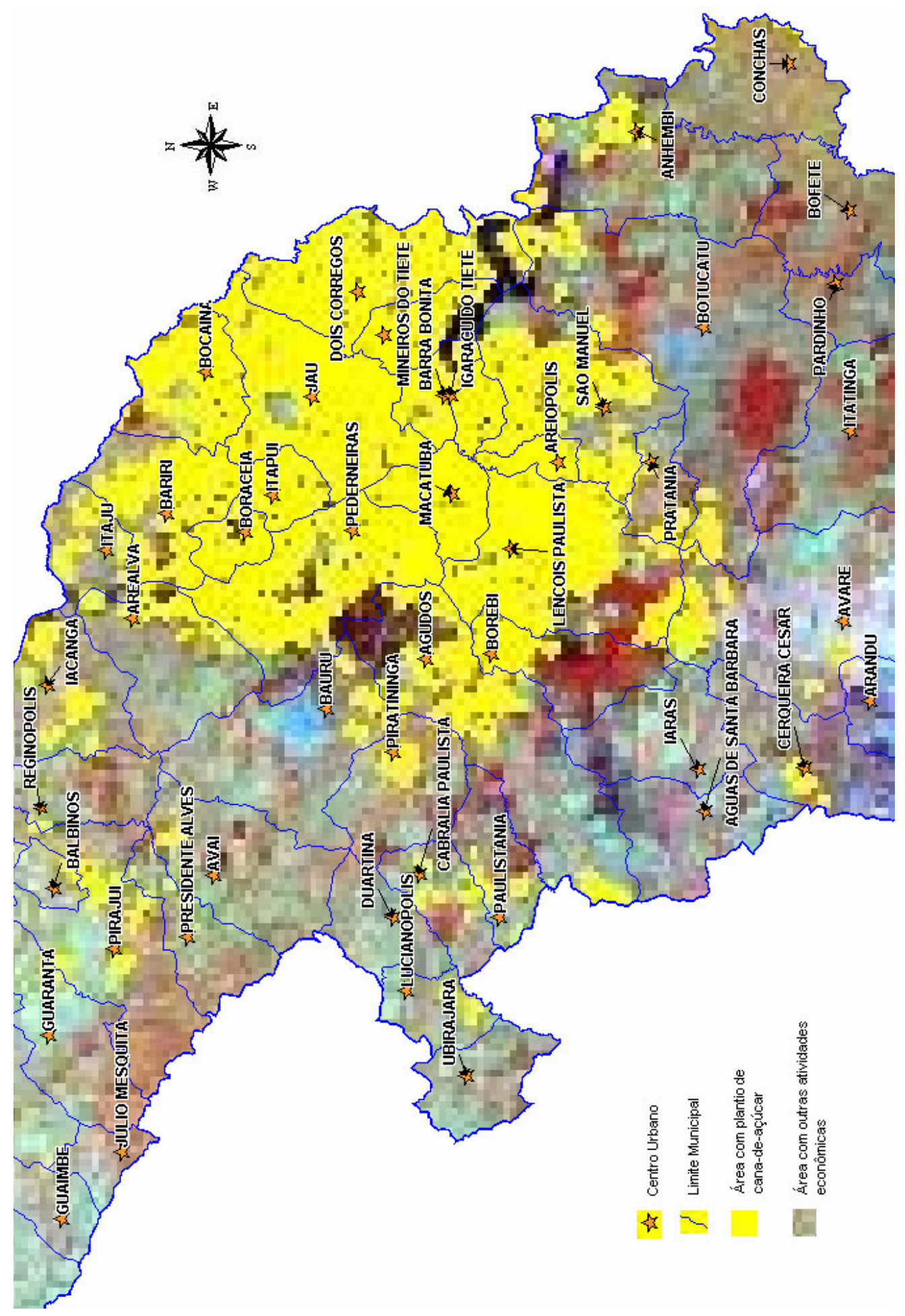

Mapa 27 - Meso-região de Bauru parcial apresentando a localização dos centros urbanos e áreas de plantio de cana-de-açúcar. Fontes: IBGE, 2004; COPERSUCAR, 2005; Organizado pelo autor. 


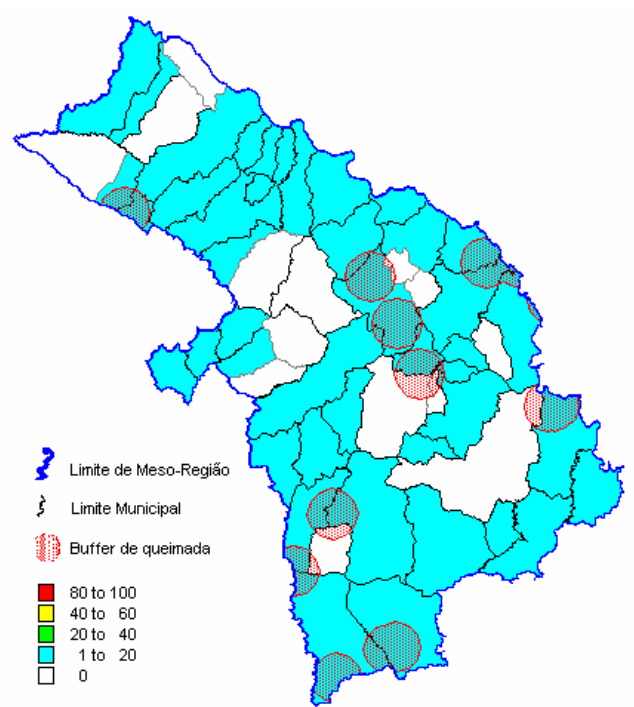

Mapa 28 - Distribuição da incidência de internações por afecções nas vias respiratórias e buffer dos focos de calor na meso-região administrativa de Bauru, do Estado de São Paulo no primeiro trimestre de 2004. Fontes: DATASUS, 2004; IBGE, 2004; INPE, 2005; Organizado pelo autor.

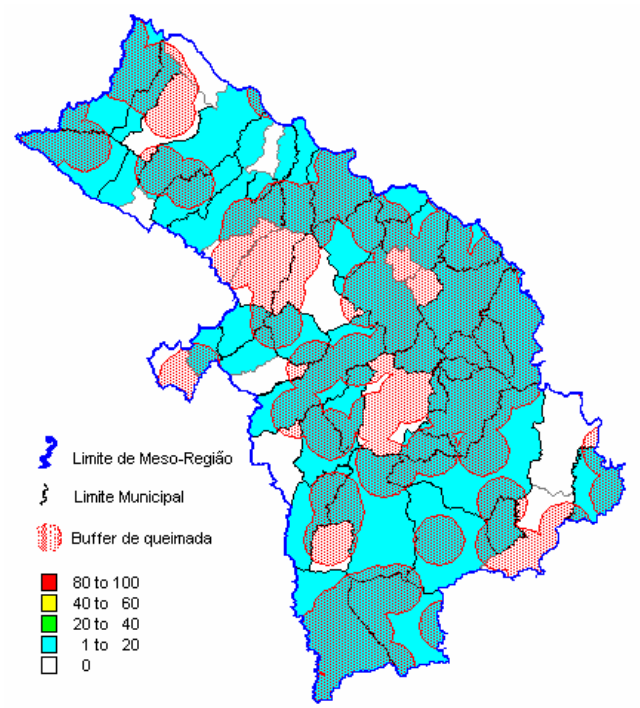

Mapa 30 - Distribuição da incidência de internações por afecções nas vias respiratórias e buffer dos focos de calor na meso-região administrativa de Bauru, do Estado de São Paulo no terceiro trimestre de 2004. Fontes: DATASUS, 2004; IBGE, 2004; INPE, 2005; Organizado pelo autor.

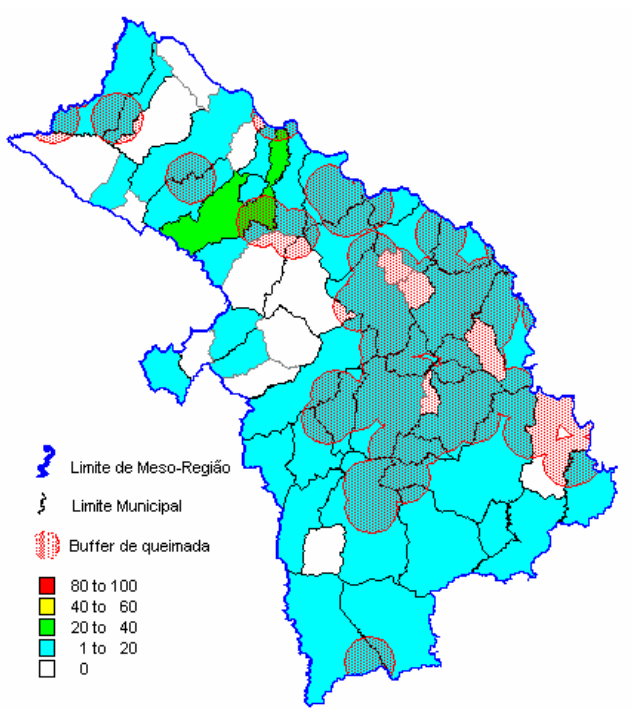

Mapa 29 - Distribuição da incidência de internações por afecções nas vias respiratórias e buffer dos focos de calor na meso-região administrativa de Bauru, do Estado de São Paulo no segundo trimestre de 2004. Fontes: DATASUS, 2004; IBGE, 2004; INPE, 2005; Organizado pelo autor.

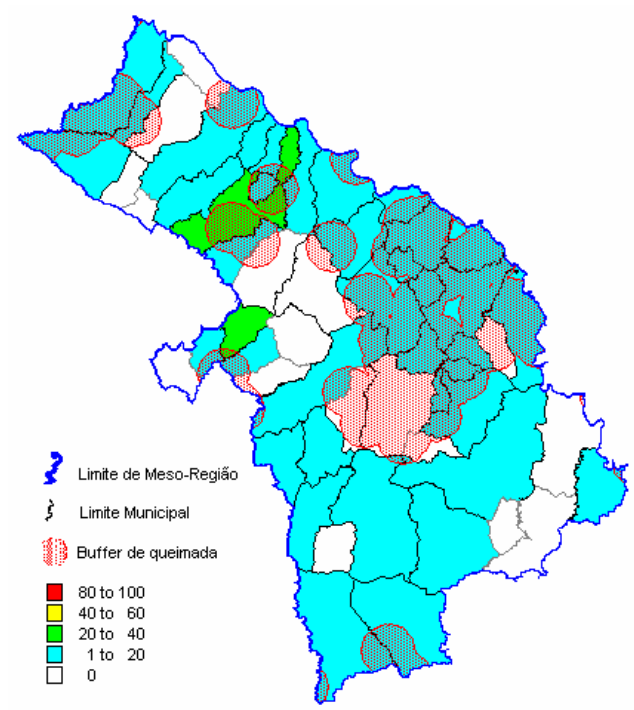

Mapa 31 - Distribuição da incidência de internações por afecções nas vias respiratórias e buffer dos focos de calor na meso-região administrativa de Bauru, do Estado de São Paulo no quarto trimestre de 2004. Fontes: DATASUS, 2004; IBGE, 2004; INPE, 2005; Organizado pelo autor. 
Nesta escala, os clusters (agrupamentos) de interesse para estudos ficam mais claros, permitindo uma melhor avaliação dos fenômenos pesquisados.

Exceto os municípios de Pirajuí e Duartina que apresentaram incidência entre 20 e 40 internações para cada 10.000 habitantes, os demais municípios mantiveram o padrão entre 1 e 20 internações para cada 10.000 habitantes.

Todos os municípios da micro-região de Jaú (Bariri, Barra Bonita, Bocaina, Boracéia, Dois Córregos, Igaraçu do Tietê, Itajú, Itapuí, Jaú, Macatuba, Mineiros do Tietê e Pederneiras) apresentam incidência maior que zero para o agravo. Juntos, compõem um núcleo de intenso cultivo de cana-de-açúcar e possuem vários focos de calor dentro de seus limites municipais.

A micro-região de Jaú, composta por 12 dos 56 municípios da meso-região de Bauru, isoladamente é responsável por $45,8 \%$ dos focos de calor ocorridos em 2004 nesta meso-região conforme apresenta a Tabela 1, bem como totaliza $38,5 \%$ das internações por afecção das vias aéreas superiores neste mesmo ano, de acordo com a Tabela 2.

Tabela 1 - Comparativo de ocorrência de focos de calor na meso-região de Bauru e micro-região de Jaú no ano de 2004. Fonte: INPE, 2005; Elaborado pelo autor.

\begin{tabular}{c|c|cc}
\hline \multirow{2}{*}{ Trimestres } & $\begin{array}{c}\text { Meso-região } \\
\text { Bauru }\end{array}$ & \multicolumn{2}{|c}{$\begin{array}{c}\text { Micro-região } \\
\text { Jaú }\end{array}$} \\
\cline { 2 - 4 } & Focos de calor & Focos de calor & Porcentagem \\
\hline $1^{\circ}$ & 13 & 5 & $38,5 \%$ \\
$2^{\circ}$ & 104 & 46 & $44,2 \%$ \\
$3^{\circ}$ & 257 & 110 & $42,8 \%$ \\
$4^{\circ}$ & 122 & 66 & $54,1 \%$ \\
\hline Total & 496 & 227 & $45,8 \%$ \\
\hline
\end{tabular}


Tabela 2 - Comparativo de ocorrência de internações por afecção das vias respiratórias na meso-região de Bauru e micro-região de Jaú no ano de 2004. Fonte: INPE, 2005; Elaborado pelo autor

\begin{tabular}{c|c|cc}
\hline \multirow{2}{*}{ Trimestres } & $\begin{array}{c}\text { Meso-região } \\
\text { Bauru }\end{array}$ & \multicolumn{2}{|c}{$\begin{array}{c}\text { Micro-região } \\
\text { Jaú }\end{array}$} \\
\cline { 2 - 4 } & Internações & Internações & Porcentagem \\
\hline $1^{0}$ & 314 & 122 & $38,8 \%$ \\
$2^{o}$ & 522 & 180 & $34,5 \%$ \\
$3^{o}$ & 459 & 203 & $44,2 \%$ \\
$4^{\circ}$ & 420 & 155 & $36,9 \%$ \\
\hline Total & 1.715 & 660 & $38,5 \%$ \\
\hline
\end{tabular}

A comparação dos valores dispostos nas duas tabelas anteriores, reforça a tese que há correlação entre causa/efeito na micro-região de Jaú, porém quando a comparação é feita para a meso-região, a correlação se perde, indicando a influência de outros fatores nesta abordagem. O gráfico 3 apresenta estes resultados.

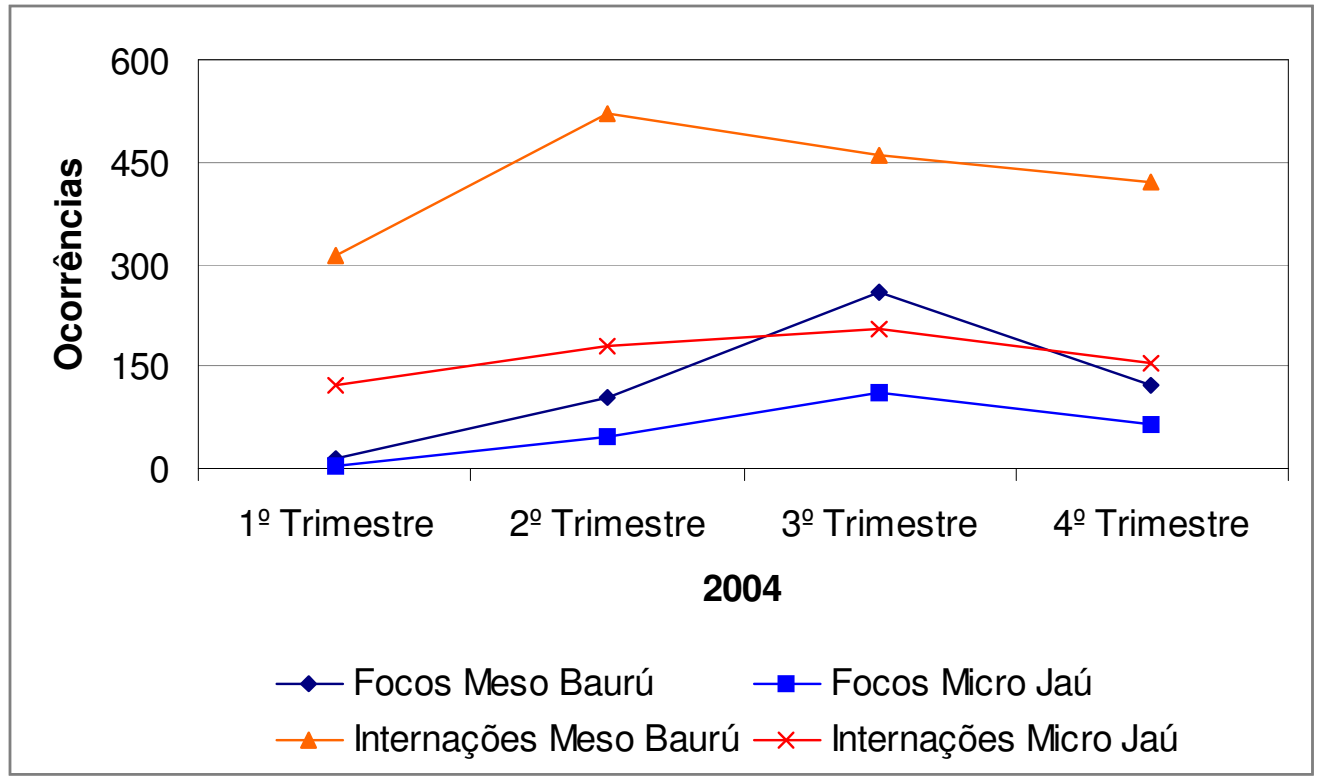

Gráfico 3 - Comparativo entre ocorrências de focos de calor e internações por afecções na meso-região de Bauru e micro-região de Jaú nos trimestre do ano de 2004. Fontes: DATASUS, 2004; INPE, 2005; Elaborado pelo autor. 


\subsection{Análise do Enfoque Local}

Os mapas temáticos construídos na fase anterior, possibilitaram observar a distribuição correlacionada dos agravos ambientais e dos problemas de saúde. Em particular, a meso-região administrativa de Bauru despertou interesse devido ao fato de possibilitar agrupar seus 56 municípios em três situações distintas. A primeira, devido à grande concentração de áreas de plantio aglutinada em 17 municípios: Agudos, Areiópolis, Barra Bonita, Bariri, Bocaina, Boracéia, Borebi, Dois Córregos, Igaraçu do Tietê, Itajú, Itapuí, Jaú, Lençóis Paulista, Macatuba, Mineiros do Tietê, Pederneiras e São Manuel pertencentes às micro-regiões de Jaú e Bauru. Fato este, gerador de intensa atividade de queimadas e causador de vários transtornos à população que ali vive.

Mais ao norte desta área, os municípios de Avaí, Cafelândia, Getulina, Guaiçara, lacanga, Lins, Pirajuí, Promissão e Sabino, pertencentes às micro-regiões de Lins e Bauru, desenvolvem a cultura canavieira, porém com menor intensidade que o aglutinado anterior.

Por fim, os demais municípios desta meso-região, não apresentam as mesmas características pois desenvolvem outros tipos de atividade econômica.

O Mapa 27, apresenta áreas de plantio de cana-de-açúcar em Pirajuí. Os mapas 28 a 31 evidenciam a presença de internações e queimadas neste mesmo município. Fato inverso ocorre no município de Duartina, os mesmos mapas mostram que a área deste município não produz cana-de-açúcar e não apresenta focos de calor. Porém, apresenta a mesma classificação de internações que Pirajuí. Logo, a 
correlação causa/efeito entre queimada e internação por afecções não permite explicar da mesma forma a incidência nos dois municípios.

Fato diferenciado ocorre na micro-região de Jaú, onde mapas e gráficos apontam a correlação causa/efeito, mas estes resultados não são determinísticos, apenas sugerem hipóteses para estudos mais aprofundados.

Considerando que no ano 2004 produziram-se 496 focos de calor no entorno de uma área que abriga 292.197 habitantes, proporcionalmente este processo gerou uma queimada para cada 500 habitantes. Outrossim, tal população representa $23,9 \%$ da mesoregião e tem que conviver com $45,8 \%$ dos focos de calor, e sobreviver com $38,5 \%$ das internações que provavelmente ocorreram em função do problema ambiental exposto. 


\section{CONCLUSÕES E RECOMENDAÇÕES}

Neste momento, precisamente maio de 2005, mais uma vez, como ocorreu nos últimos 5 anos, outro período de colheita de canade-açúcar, iniciou-se no Estado de São Paulo. Grandes áreas de monocultura canavieira, estão prontas para queimar e proporcionar subempregos aos 1 milhão de trabalhadores que vivem do corte da cana. Segundo o decreto 47.700 , de 11 de março de 2003, ainda será assim por mais, 26 anos até o prazo final de eliminação do processo de queimada em 2031.

Ainda que não houvesse correlação encontrada neste estudo para justificar os agravos à saúde, só os transtornos vivenciados pela população impactada, tais como sujeira em casas e locais públicos, acidentes em rodovias por falta de visibilidade e interrupção de fornecimento de energia elétrica por problemas nas linhas de transmissão, já seria suficiente para eliminar as queimadas. Soma-se a isso, os condicionantes ambientais envolvidos na questão, queima de biomassa, emissão de $\mathrm{CO}_{2}$, entre outros compostos, gerando impactos na natureza desconhecidos ainda pelo homem.

Considerando que saúde pública implica em promover a saúde e garantir qualidade de vida das coletividades, este trabalho buscou apresentar ferramentas fomentadoras de hipóteses para estudos que vão ao encontro a estes objetivos.

Sabe-se das dificuldades comuns aos profissionais de saúde quanto ao uso de sofisticadas tecnologias computacionais em estudos desta natureza. Contudo, cabe ao profissional de informática, ser um facilitador de recursos, integrando-se ao contexto de tais 
necessidades. Os SIGs estão presentes em muitos estudos de saúde pública, porém quase sempre estão limitados a um usuário que interessou-se pelos recursos e resolveu aprender mais sobre como utilizá-lo.

Em relação aos objetivos inicialmente propostos para este estudo, o SIG foi construído e gerou resultados satisfatórios, uma vez que o enfoque local apresentou subsídios que indicam a correlação entre queimadas e internações por afecções das vias respiratórias. Algumas técnicas como, sobreposição de camadas, ampliação de escala, buffer e cluster, foram utilizadas e discutidas no transcorrer do trabalho, configurando em objetivos desenhados e atendidos.

Após a conclusão do SIG, foi possível analisar a correlação espacial nas cartas temáticas, que permitiram fazer os melhores recortes de observação para os fenômenos esperados. Concluídas as análises, elaborou-se um relato dos fenômenos observados juntamente com a discussão sobre o uso das tecnologias empregadas.

O capítulo 5 deste estudo apresentou mapas em escala regional que confirmaram a existência de coincidências entre áreas de plantio de cana-de-açúcar, focos de queimada e elevadas incidências de internações por afecções das vias respiratórias. Porém, a imprecisão gerada nesta escala não permitiu resultados conclusivos.

$\mathrm{Na}$ seqüência, os mapas elaborados com enfoque local, apontaram correlação causa/efeito entre as variáveis estudadas na micro-região de Jaú. Os resultados são mais precisos nesta escala, porém, a natureza desta pesquisa não permitiu resultados determinísticos, somente dados para auxiliar a formulação de novas hipóteses. Assim sendo, este estudo estimulou a elaboração de pesquisas mais aprofundadas para o tema em questão. 
Portanto, as tecnologias de SIG mostraram-se úteis neste estudo exploratório, pois possibilitaram observar, na mesma perspectiva, dados sobre a exposição humana aos compostos produzidos em queimadas e os problemas de saúde respiratória que impactaram a população, confirmando assim a hipótese desta pesquisa.

A título de futuros trabalhos neste âmbito, faz-se necessário o investimento em estudos envolvendo a modelagem da pluma de poluentes, com vistas a determinar se a causa (queimadas) de fato culmina nos agravos da saúde, reduzindo a qualidade de vida nas populações impactadas. 


\section{REFERÊNCIAS}

1. [Anonymus] Brasil começa a mover mercado de carbono. Folha de São Paulo, São Paulo, 2005 fev 16; cad Ciência; p. A16.

2. Almeida Filho N, Rouquayrol MZ. Introdução à Epidemiologia. $3^{\underline{a}}$ ed. Rio de Janeiro: MEDSI; 2002.

3. Alvarenga AT. A Saúde Pública como campo de investigação interdisciplinar e a questão metodológica. Saúde e Sociedade 1994; 3(2): 23-41.

4. Amaral L. A cana-de-açúcar. História Geral da Agricultura Brasileira. 2 $2^{\mathrm{a}}$ ed. São Paulo: Companhia Editora Nacional, 2:326-40, 1958.

5. Andreae MO, et al. Smoking Rain Clouds over de Amazon. Science Magazine 2004; 303:1337-1342.

6. Arbex MA. Avaliação dos efeitos do material particulado proveniente da queima da plantação de cana-de-açúcar sobre a morbidade respiratória na população de Araraquara - SP. São Paulo; 2001. [Tese de Doutorado - Faculdade de Medicina da Universidade de São Paulo].

7. Aurélio BHF. Dicionário Aurélio Básico de Língua Portuguesa. São Paulo: Editora Nova Fronteira; 1988.

8. Azevedo F. Obras Completas volume XI: Canaviais e Engenhos na vida Política do Brasil, Ensaio Sociológico sobre o elemento político na civilização do açúcar. $2^{\mathrm{a}}$ ed. São Paulo: Melhoramentos; 1958. 
9. Bailey TC. Spatial statistical methods in health. Cadernos de Saúde Pública 2001; 17(5): 1083 - 1098.

10.Barcellos C, Bastos FI. Geoprocessamento, ambiente e saúde: Uma união possível? Cadernos de Saúde Pública 1996; 12(3): $389-397$.

11.Barcellos C. Exemplos de Aplicações de SIG. 2000 [Material apresentado no Curso de Atualização em Geoprocessamento aplicado à Saúde, ENSP].

12.Barquera S, Rico-Méndez FG, Tovar V. Methodology in the epidemiological research of respiratory diseases and environmental pollution. Revista Saúde Pública 2002; 36(1): $107-113$.

13.BNDES - Banco Nacional de Desenvolvimento Econômico e Social. Efeito Estufa e a Convenção sobre Mudança do Clima. 2001; 1.[39 páginas]. Disponível em <URL: http:// www.mct.gov.br/clima/brasil/energia.htm> [2004 jul 08].

14.Bousquat $A$, Cohn $A$. A dimensão espacial nos estudos sobre saúde: uma trajetória histórica. História, Ciências, Saúde Manguinhos 2004; 11(3): 549-568.

15.Brasil. Lei Federal № 8.080, de 19 de setembro de 1990. Dispõe sobre a lei orgânica da saúde. Diário Oficial da União, Brasília, 20 de setembro de 1990.

16.Câmara G, Davis C, Monteiro AMV. Introdução à Ciência da Geoinformação. [livro online] 2001; 1.[5 páginas]. Disponível em <URL: http://www.dpi.inpe.br/gilberto/livro/introd/index.html> [2003 abr 13]. 
17.Camargo-Neves, et al. Utilização de Ferramentas de Análise espacial na vigilância epidemiológica de leishmaniose visceral americana - Araçatuba, São Paulo, Brasil, 1998 - 1999. Cadernos de Saúde Pública 2001; 17(5): 1263 - 1267.

18.Cançado JED. A poluição atmosférica e sua relação com a saúde humana na região canavieira de Piracicaba - SP. São Paulo; 2003 [Tese de Doutorado - Faculdade de Medicina da Universidade de São Paulo].

19.Candé JF. Coleção Canavieira no 7: A cana-de-açúcar na vida brasileira - Textos Coligidos. Rio de Janeiro: MIC Ministério da Indústria e Comércio; 1971.

20.Carvalho MS, Pina MF e Santos SM. Conceitos básicos de Sistemas de Informação Geográfica e cartografia aplicados à saúde. MS - Ministério da Saúde. Rede Interagencial de Informações para a Saúde RIPSA.Brasília(DF); 2000.

21.Castro HA, Gouveia N, Escamilla-Cejudo JA. Questões metodológicas para a investigação dos efeitos da poluição do ar na saúde. Revista Brasileira de Epidemiologia 2003; 6(2): 135 $-149$.

22.Chiesa AM, Westphal MF, Kashiwagi NM. Geoprocessamento e a promoção da saúde: Desigualdades sociais e ambientais em São Paulo. Revista Saúde Pública 2002; 36(5): 559 - 567.

23.Cicero-Fernandez PC, et al. Evaluation of Human Exposure to Ambient $\mathrm{PM}_{10}$ in the Metropolitan Area of Mexico City Using as GIS-Based Methodology. Air \& Waste Manage. Assoc. 2001; $51: 1586-1593$. 
24.Copersucar. Mosaico digital obtido por satélite das áreas de cultivo de cana-de-açúcar no Estado de São Paulo. Centro de Tecnologia Copersucar. São Paulo; 2005.

25.Costa GF. Geoprocessamento: Uso e aplicação na Saúde Pública e na Saúde Ambiental. São Paulo; 2002 [Dissertação de Mestrado - Faculdade de Saúde Pública da Universidade de São Paulo].

26.Coura JR. Endemias e Meio Ambiente no Século XXI. Cadernos de Saúde Pública 1992; 8(3): 335 - 341.

27.DATASUS - Processamento de Dados do SUS. Procedimentos hospitalares do SUS. Disponível em <http://tabnet.datasus. gov.br/cgi/deftohtm.exe?sih/cnv/prsp.def> [2004 jan 08].

28.Date CJ, Introdução a Sistemas de Bancos de Dados. $7^{\text {a }}$ ed. Rio de Janeiro: Campus; 2000.

29.Diegues ACS. O mito moderno da natureza intocada. São Paulo: NUPAUB/USP, 1994.

30.Diegues ACS. Ecologia Humana e Planejamento em Áreas Costeiras. São Paulo: NUPAUB /USP, 1995.

31.EMBRAPA - Empresa Brasileira de Pesquisa Agropecuária. Agroecologia da cana-de-açúcar. Disponível em <http://www.cana.cnpm.embrapa.br/agroeco.html> [2004 jan 08].

32.Forattini OP. Ecologia, Epidemiologia e Sociedade. São Paulo: Artes Médicas, Edusp, 1992.

33.Forattini OP. Pesquisa em saúde pública. Revista de Saúde Pública 1995; 29(2): $81-88$. 
34.Galvão LA, coordenador. Indicadores de Saúde e Ambiente: Relatório da Oficina de Trabalho realizada durante o IV Congresso Brasileiro de Epidemiologia - EPIRIO-98. IESUS 1998; VII(2):45 - 53.

35.Goldemberg J. Uma nova OPEP. O Estado de São Paulo. São Paulo, 2005 jan 18; p.A2.

36.Gouveia $\mathrm{N}$, et al. Saúde e Meio ambiente em São Paulo utilizando Sistemas de Informação Geográfica (SIG): Uma nova Ferramenta para Epidemiologia Ambiental. São Paulo; 2003. [Trabalho apresentado em Simpósio da Faculdade de Medicina da USP].

37.Greenwich Mean Time. Greenwich Mean Time (GMT): World Time. Disponível em <URL: http://wwp.greenwichmeantime. com> [2005 mai 10].

38.IBGE - Instituto Brasileiro de Geografia e Estatística. Catálogo IBGE. Disponível em <URL: http://www.ibge.gov.br> [2004 jan 08].

39.Inácio J. A nova era da cana-de-açúcar. Agrinova Web. Disponível em <URL: http://www.agrinovaweb.com.br/agw_ imprimir. vxlpub?codnoticia $=77521>$ [2005 jan 27].

40.INPE - Instituto Nacional de Pesquisas Espaciais. Monitoramento de Queimadas. [Fotos do satélite NOAAS 12]. Disponível em <URL: http://www.dpi.inpe.br> [2003 mai 18].

41.INPE - Instituto Nacional de Pesquisas Espaciais. Monitoramento de Queimadas. [Banco de dados sobre 
queimadas]. Disponível em <URL: http://www. dpi.inpe.br/proarco/bdqueimadas> [2005 mar 24].

42.Jacquez GM . Disease Cluster Investigation and GIS: A New Paradigm? Geographic Information Systems in Public Health - Third National Conference. 1998.

43.JPEG Org. Comitê JPEG. Disponível em <URL: http://www.jpeg.org/index.html> [2005 mai 10].

44.Kimball R. Data Warehouse Toolkit. São Paulo: Makron Books; 1998.

45.Lacaz CA, Baruzzi RC, Siqueira Junior W. Introdução à Geografia Médica do Brasil. São Paulo: Ed. Blucher; 1972.

46.Leff H. Epistemologia Ambiental. São Paulo: Ed. Cortez, 2001.

47.London Health Commission. A Short Guide to Health Impact Assessment. Informing Healthy Decisions. London: NHS Executive London, Our Healthier Nation; 2000.

48.Malta DC, et al. A mortalidade infantil em Belo Horizonte, Minas Gerais, Brasil, por área de abrangência dos Centros de Saúde (1994 - 1996). Cadernos de Saúde Pública 2001; 17(5): 1189 $-1198$.

49.MapInfo. MapInfo Help. MapInfo Corporation; 2001.

50.Mello Jorge MHP, Gotlieb SLD, Laurenti R. A saúde no Brasil: análise do período 1996 a 1999. Brasília(DF): Organização Pan-Americana da Saúde; 2001. 
51. Minayo MCS. Enfoque Ecossistêmico de Saúde e Qualidade de Vida. In: Minayo MCS, Miranda AC, coordenadores. Saúde e Ambiente Sustentável: Estreitando Nós. Rio de Janeiro: Ed. FIOCRUZ; 2002. p. $173-189$.

52.Miranda EE, Dorado AJ, Assunção JV. Doenças respiratórias crônicas em quatro municípios paulistas. $2^{\underline{a}}$ ed. São Paulo: Ecoforça, Universidade de São Paulo / Universidade de Campinas; 1995.

53.Monteiro CAF. O clima e a organização do espaço no Estado de São Paulo: Problemas e Perspectivas. São Paulo: Universidade de São Paulo - Instituto de Geografia; 2001.

54.Moran F. Adaptabilidade Humana. São Paulo: EDUSP; 1994.

55.Morin E, Kern HD. Terra Pátria. Portugal: Instituto Piaget; 1993.

56.Moreira AM. Fundamentos do Sensoriamento Remoto e Metodologias de Aplicação. São José dos Campos: Instituto Nacional de Pesquisas Espaciais (INPE); 2001.

57.Muñoz $\mathrm{F}$, et al. Las funciones essenciales de la salud pública: un tema emergente en las reformas del sector de la salud. Revista Panamericana de Salud Pública 2000; 8(1/2): 126-134.

58.Naomar AF, Rouquayrol MZ. Introdução à Epidemiologia. Rio de Janeiro: MEDSI; 2002.

59.OPAS - Organização Pan-Americana da Saúde. Programa Especial de Análise em Saúde. Sistemas de informação Geográfica em Saúde. Brasília(DF); 2002. 
60.Pádua JA. Dois Séculos de Crítica Ambiental no Brasil. In: Minayo MCS, Miranda AC, coordenadores. Saúde e Ambiente Sustentável: Estreitando Nós. Rio de Janeiro: Ed. FIOCRUZ; 2002. p. $173-189$.

61.Penha M. Aspectos históricos da Saúde Pública na realidade brasileira. São Paulo; 2003. [Transparências da disciplina Saúde Pública: Campo de Conhecimento - Faculdade de Saúde Pública da USP].

62.Pinto ES. Cana de Açúcar. Rio de Janeiro: Edições SIA; 1965.

63.Ribeiro H. Poluição do Ar e Doenças Respiratórias em Crianças da Grande São Paulo: Um estudo de Geografia Médica. São Paulo; 1988 [Tese de Doutorado - Faculdade de Filosofia, Letras e Ciências Humanas da Universidade de São Paulo].

64.Ribeiro H. Análise Espacial e Saúde Pública. In: DOWBOR L \& KILSTAJN S. Economia Social no Brasil. São Paulo: SENAC, $2001 ; 241-250$.

65.Ribeiro H, Assunção JV. Efeitos das queimadas na saúde humana. Estudos Avançados 2002; 16 (44): 125 - 148.

66. Rosen G. Da Polícia Médica à Medicina Social: Ensaios sobre a história da assistência médica. Rio de Janeiro: Ed. Graal, 1980.

67.Rouquayrol MZ. Epidemiologia \& Saúde. Rio de Janeiro: MEDSI; 1993.

68.Santos M. A Natureza do Espaço. São Paulo: EDUSP; 2002. 
69.Santos SM, et al. Detecção de aglomerados espaciais de óbitos por causas violentas em Porto Alegre, Rio Grande do Sul, Brasil, 1996. Cadernos de Saúde Pública. Rio de Janeiro 2001; 17(5): $1141-1151$.

70.São Paulo (Estado). Decreto Estadual no 8468, de 8 de setembro de 1976. Dispõe sobre a Prevenção e o Controle da Poluição do Meio Ambiente. Diário Oficial do Estado de São Paulo, São Paulo, 8 de setembro de 1976.

71. Decreto Estadual no 47.700, de 11 de março de 2003. Regulamenta a Lei 11.241 , de 19 de setembro de 2002 , que dispõe sobre a eliminação gradativa da queima da palha da cana-de-açúcar e dá providências correlatas. Diário Oficial do Estado de São Paulo, São Paulo, 18 de março de 2003.

72.SEADE - Fundação Sistema Estadual de Análise de Dados. Informações dos municípios paulistas. Disponível em <URL: http://www.seade.gov.br> [2004 jan 08].

73.Seinfeld JH, Pandis SN. Atmospheric Chemistry and Physics: from Air Pollution to Climate Change. New York: Wiley; 1998.

74.Severino AJ. Metodologia do Trabalho Científico. São Paulo: Cortez; 2002.

75.Silberschatz A, Korth HF, Sudarshan S. Sistema de Banco de Dados. 3aㅡ ed. São Paulo: Makron Books; 1999.

76.Silva AB. Sistemas de Informações Geo-Referenciadas: Conceitos e Fundamentos. Campinas: Editora da UNICAMP; 1999. 
77.Snow J. Sobre a maneira de transmissão do cólera. São Paulo: Hucitec; Rio de Janeiro: Abrasco; 1999.

78.Soares, AR. Um século de economia açucareira. Evolução da moderna agroindústria do açúcar em São Paulo de 1877 a 1970. São Paulo: Ed. Clíper; 2000.

79.SPSS Inc. Software \& Solutions - SPSS Family. Disponível em <URL: http://www.spss.com> [2004 jan 08].

80.Stavenhagen R. Etnodesenvolvimento: Uma Dimensão Ignorada no Pensamento Desenvolvimentista. In: Oliveira RC, coordenador. Anuário Antropológico / 84. Rio de Janeiro: Tempo Brasileiro; 1985. p.11-44.

81.Única - União da Agroindústria Canavieira de São Paulo. Agroindústria da cana-de-açúcar: Alta competitividade canavieira. Disponível em <URL:http//www.unica.com.br/ pages/agroindustria_alta.asp $>$ [2003 mai 10]

82.USP - Universidade de São Paulo. Faculdade de Saúde Pública. Núcleo de Assistência Médico Hospitalar - NAMH/FSP. Sistemas de Informação em Saúde para Municípios. São Paulo; 1998.

83.USP - Universidade de São Paulo. Faculdade de Saúde Pública. Biblioteca/CIR. Guia de Apresentação de Teses. São Paulo; 2001.

84.Vine MF, Degnan D, Hanchette C. Geographic Information Systems: Their Use in Environmental Epidemiologic Research. Environmental Health Perspectives 1997; 105(6): 598 - 605. 
85.WHO - World Health Organization. CID-10 Classificação Internacional de Doenças $10^{\underline{a}}$ ed; São Paulo: Centro Brasileiro de Classificação de Doenças - Universidade de São Paulo; 1993.

86.WHOa - World Health Organization. Guias para la Calidad del Aire. Genebra: World Health Organization; 1999.

87.WHOb - World Health Organization. Health Guidelines for Vegetation Fire Events. ed. Schwela DH, Goldammer JG, Morawska LH, Simpson O. Genebra: World Health Organization; 1999. Disponível em <URL:http://www.who.int/docstore/ peh/Vegetation_fires/Backgroundpapers/BackgrPap1.pdf> [2004 jan 06].

88.Zancul A. O efeito da queimada de cana-de-açúcar na qualidade do ar de região de Araraquara. São Carlos; 1998. [Dissertação de Mestrado - Escola de Engenharia de São Carlos da Universidade de São Paulo]. 